DOE/RL-2000-72

Revision 1

\title{
Performance Assessment Monitoring Plan for the Hanford Site Low-Level Burial Grounds
}

Prepared for the U.S. Department of Energy Assistant Secretary for Environmental Management Pacific Northwest National Laboratory for the

U.S. Department of Energy under Contract DE-AC05-76RL01830

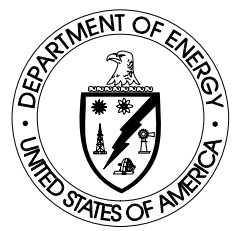

United States Department of Energy P.O. Box 550

Richland, Washington 99352 


\section{TRADEMARK DISCLAIMER}

Reference herein to any specific commercial product, process, or service by trade name, trademark, manufacturer, or otherwise, does not necessarily constitute or imply its endorsement, recommendation, or favoring by the United States Government or any agency thereof or its contractors or subcontractors.

This report has been reproduced from the best available copy. Available in paper copy and microfiche.

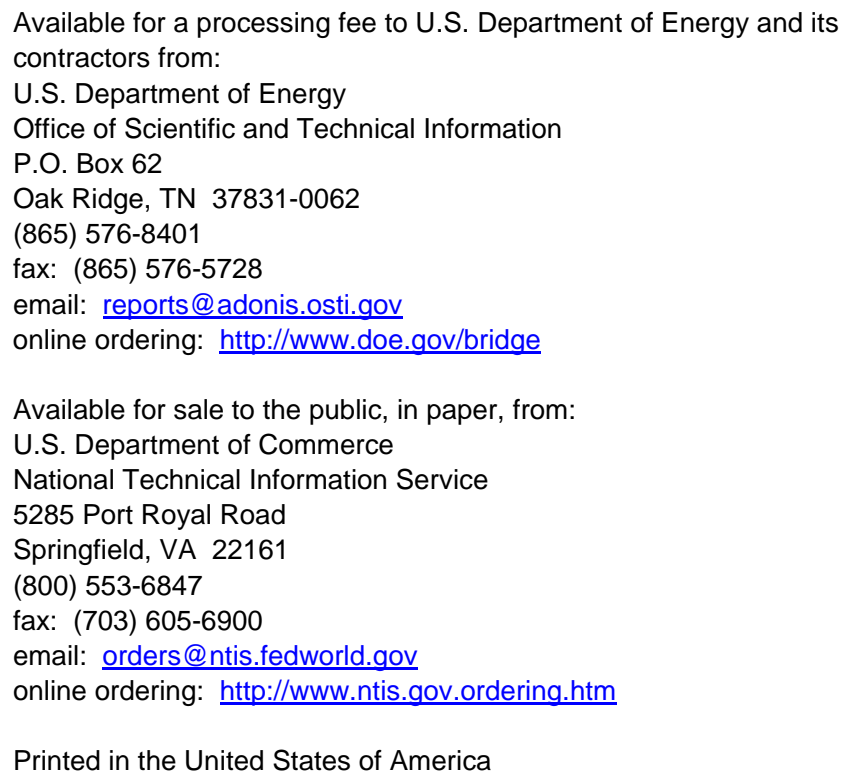


DOE/RL-2000-72

Revision 1

\section{Performance Assessment Monitoring Plan for the Hanford Site Low-Level Burial Grounds}

Date Published

March 2006

Prepared for the U.S. Department of Energy Assistant Secretary for Environmental Management Pacific Northwest National Laboratory for the

U.S. Department of Energy under Contract DE-AC05-76RL01830

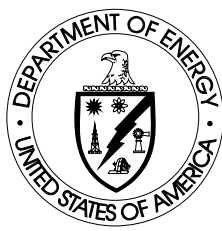

\section{United States} Department of Energy P.O. Box 550

Richland, Washington 99352 


\section{Summary}

The U.S. Department of Energy (DOE) Order 435.1, Radioactive Waste Management, requires a disposal authorization statement authorizing operation (or continued operation) for low-level waste disposal facilities. In fulfillment of these requirements, a disposal authorization statement was issued on October 25, 1999, authorizing the Hanford Site to transfer, receive, possess, and dispose of low-level radioactive waste at the 200 East Area burial grounds and the $200 \mathrm{West}$ Area burial grounds. One of the conditions is that monitoring plans for the 200 East Area and 200 West Area low-level burial grounds be written and approved by the Richland Operations Office.

By agreement between DOE and the Washington State Department of Ecology, use of the low-level burial ground (LLBG) as a disposal facility for low-level and mixed low-level wastes has been restricted to lined trenches and the Navy reactor-compartment trench only. Hence, as of July 2004, only the two lined trenches in burial ground 218-W-5 (trenches 31 and 34) and the Navy reactor-compartment trench in burial ground 218-E-12B (trench 94) are allowed to receive waste. When the two lined trenches are filled, the LLBG will cease to operate except for reactor compartment disposal at trench 94. Remaining operational lifetime of the LLBG is dependent on waste volume disposal rates.

Existing programs for air sampling and analyses and subsidence monitoring are currently adequate for performance assessment at the LLBG. In order to ensure complete coverage, monitoring programs (e.g., Resource Conservation and Recovery Act [RCRA], Comprehensive Environmental Response, Compensation, and Liability Act, and Near-Facility monitoring), the constituents, monitoring frequencies, and boundaries for each program require regular review and comparison. The annual reports discussed here are the primary sources for these reviews.

The pathways of interest are air and groundwater for both operational and post-closure conditions at the LLBG, with groundwater considered to be the most significant long-term exposure pathway. Constituents that contributed at least $0.1 \%$ of the total relative hazard were selected as target analytes for monitoring. These are technetium-99, uranium, and iodine-129. Because of its environmental unavailability, carbon-14 was removed from the list of constituents. Given the potential uncertainties in inventories at the 200 Area LLBG and the usefulness of tritium as a contaminant indicator, tritium will also be monitored as a constituent of concern at all burial grounds.

Preexisting contamination plumes in groundwater beneath low-level waste management areas are attributed to other past-practice liquid waste disposal sites. Groundwater and air will be sampled and analyzed for radiogenic components. Subsidence monitoring will also be performed on a regular basis. The existing near-facility and site-wide and offsite air monitoring programs are sufficient to satisfy the performance assessment monitoring. Groundwater monitoring will utilize the existing network of wells at the LLBG, and co-sampling with RCRA groundwater monitoring, to be sampled semiannually. Installation of additional wells is currently underway to replace wells that have gone dry. 


\section{Acronyms}

AEA

CERCLA

DOE

DOECAP

DOE-RL

EMP

EMS

HASQARD

HEIS

HMS

$\mathrm{K}_{\mathrm{d}}$

LLBG

LLWMA

MEI

QA

QC

PNNL

PUREX

RCRA

SAC

SWITS

Tri-Party

Agreement

TSDF

TRU

WIDS
Atomic Energy Act

Comprehensive Environmental Response, Compensation, and Liability Act

U.S. Department of Energy

DOE Consolidated Audit Program

DOE, Richland Operations Office

Hanford Site Environmental Monitoring Plan

Environmental Management System

Hanford Analytical Services Quality Assurance Requirements Document

Hanford Environmental Information System

Hanford Meteorology Station

distribution coefficient

low-level burial ground

low-level waste management area

maximum exposed individual

quality assurance

quality control

Pacific Northwest National Laboratory

Plutonium-Uranium Extraction (Plant)

Resource Conservation and Recovery Act

Systems Assessment Capability

Solid Waste Information Tracking System

Hanford Federal Facility Agreement and Consent Order

treatment, storage, and disposal facility

transuranic waste

Waste Information Data System 


\section{Contents}

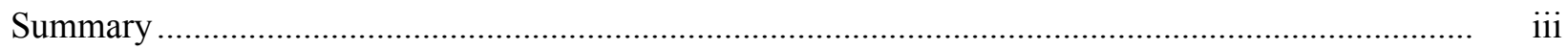

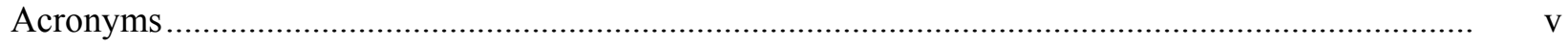

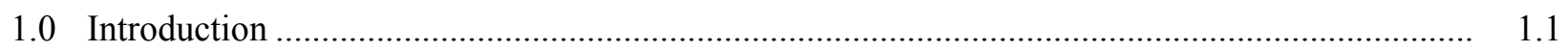

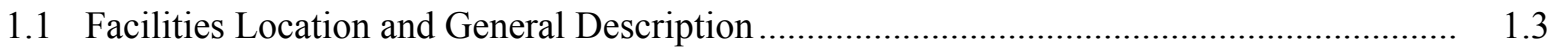

1.2 Supporting Documentation and Controls .................................................................... 1.3

2.0 Waste Management Areas Descriptions and Histories ......................................................... 2.1

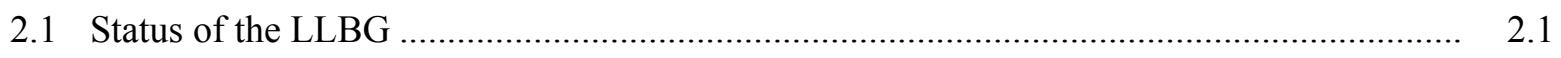

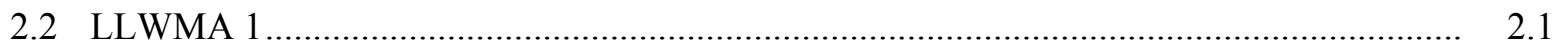

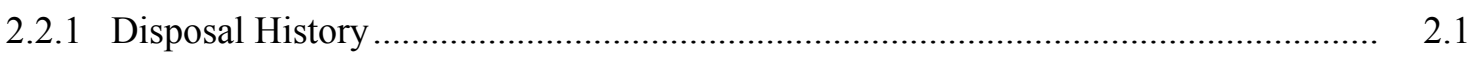

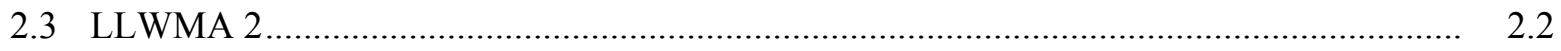

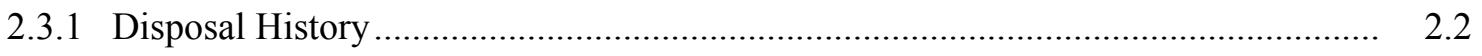

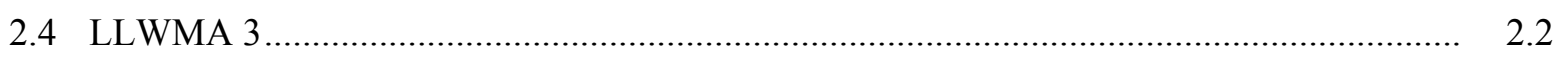

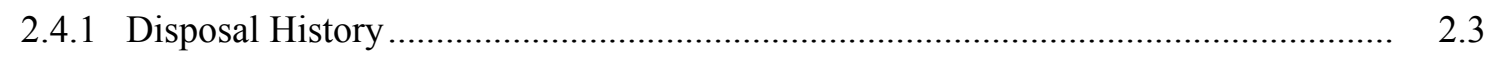

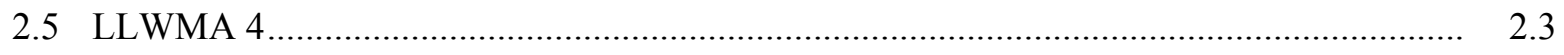

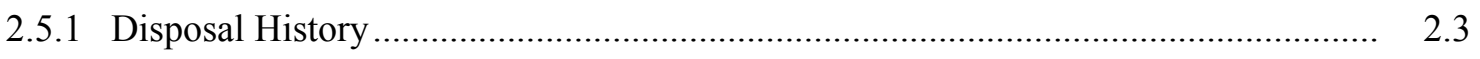

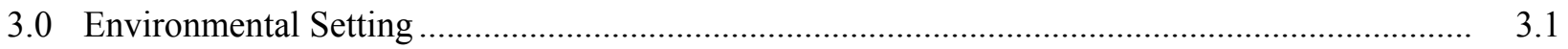

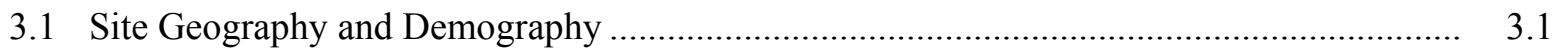

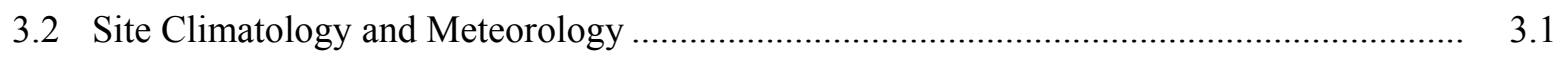

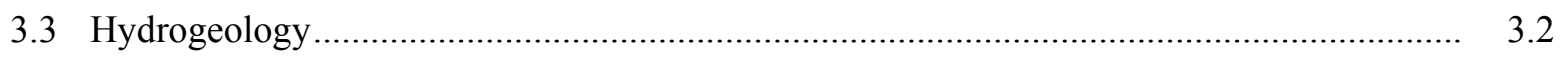

3.3.1 Hydrogeology of the 200 East Area ................................................................. 3.7

3.3.2 Hydrogeology of the 200 West Area.................................................................... 3.8

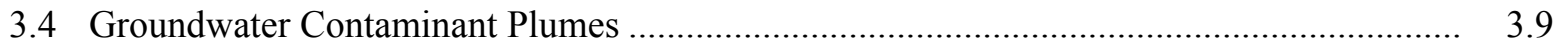

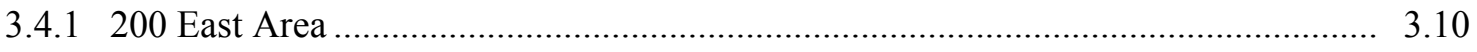

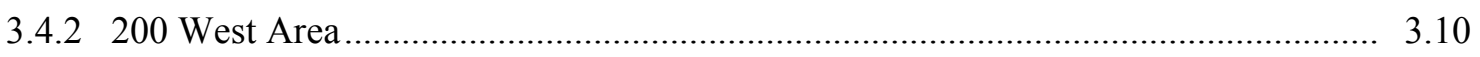

4.0 Waste Characteristics and Conceptual Model ................................................................... 4.1

4.1 Inventory and Constituents of Concern....................................................................... 4.1

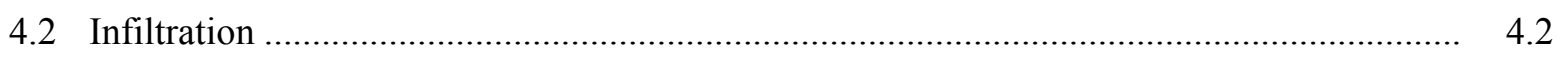

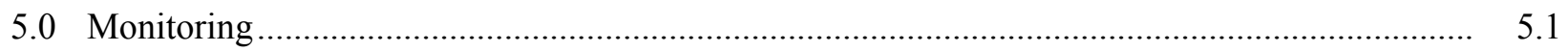

5.1 Approach Linking Performance Assessment and Operational Monitoring........................ 5.1

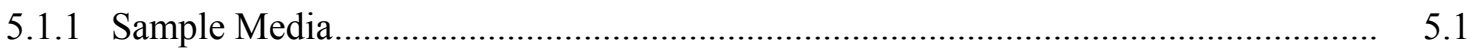

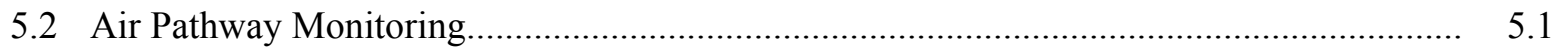

5.2.1 Near-Facility Environmental Monitoring Program ............................................. 5.1

5.2.2 Surface Environmental Surveillance Program ..................................................... 5.2

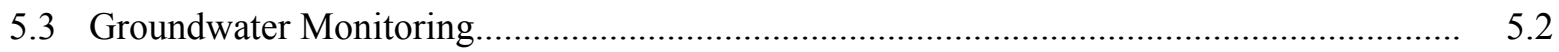


5.4 Subsidence Monitoring and Control....................................................................... 5.6

5.4.1 Operating Practices ................................................................................ 5.7

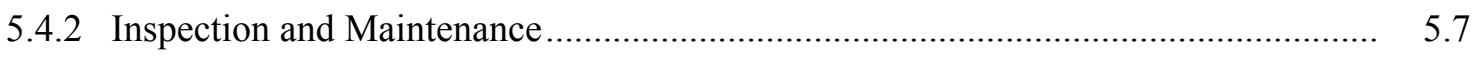

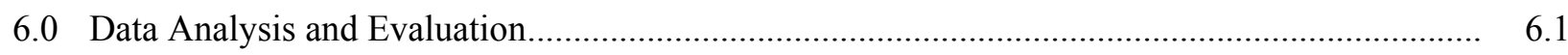

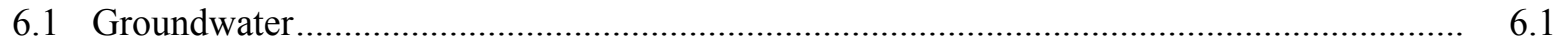

6.1.1 Compliance with Performance Standards ................................................... 6.1

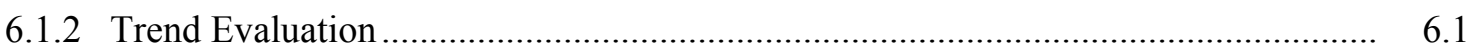

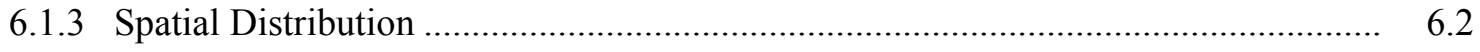

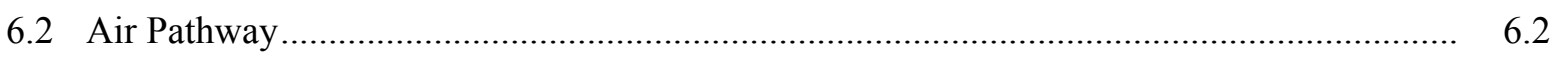

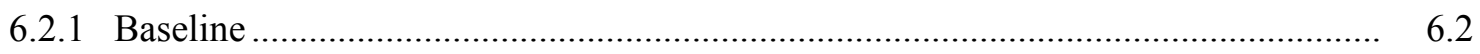

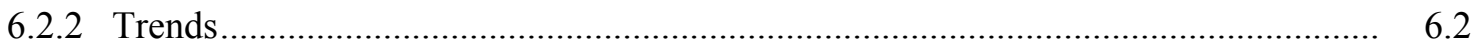

6.2.3 Compliance with Performance Objectives ..................................................... 6.3

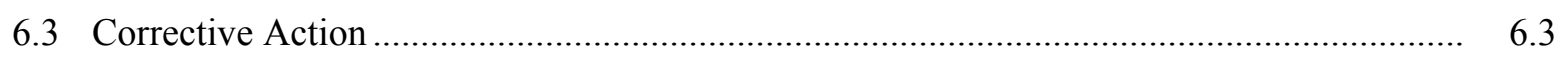

7.0 Quality Assurance and Quality Control.........................................................................

7.1 Groundwater Quality Assurance and Control ............................................................ 7.1

7.2 Air Quality Assurance and Control ............................................................................

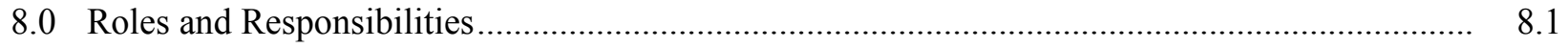

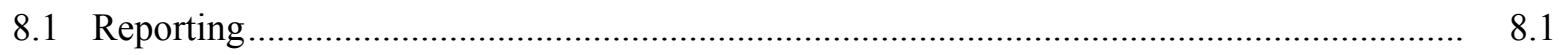

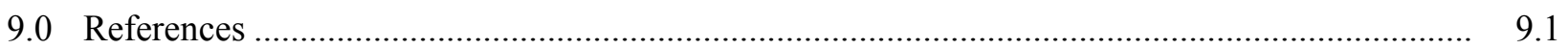

Appendix A - Groundwater Contaminant Plumes in the 200 West and 200 East Areas

Appendix B - Calculation of Relative Hazard Index for Constituents of Concern in the Groundwater Ingestion Pathway

Appendix C - Sampling and Analysis Plan for Performance Assessment Monitoring of the Low-Level Burial Grounds 


\section{Figures}

1.1 Location of 200 East and 200 West Area Low-Level Burial Grounds on the Hanford Site

3.1 Hanford Meteorological Monitoring Network Wind Roses at 10-Meter Level, 1982 Through 2004

3.2 Generalized Stratigraphy of the Hanford Site and Corresponding Hydrologic Units 3.4

3.3 Water-Table Interpretations for 1995 and 2005

4.1 Conceptual Model of Contaminant Migration under Operational and Post-Closure Conditions and Schematic of Vadose Zone Simulation Model Used for Composite Analysis

5.1 Locations of Near-Facility Air Samplers in the 200 East Area

5.2 Locations of Near-Facility Air Samplers in the 200 West Area

5.3 Site-Wide and Offsite Air Sampling Locations On and Near the Hanford Site 2003 ... 5.5

8.1 Data Collection and Reporting Road Map.

\section{Tables}

1.1 Performance Objectives for 200 East and West Area Low-Level Burial Grounds Compared with Estimates of Dose and Flux

1.2 LLWMAs Burial Grounds

4.1 List of Radiological Constituents and Groundwater Performance Objectives for the 200 East and 200 West Areas Low-Level Burial Grounds.

4.2 Category 3 Groundwater Dose Estimates by Burial Ground for Inventory Disposed September 27, 1988 to October 31, 2004 and Forecasted 2004 to Closure. 


\subsection{Introduction}

U.S. Department of Energy (DOE) Order 435.1, Radioactive Waste Management, requires a disposal authorization statement authorizing operation (or continued operation) for low-level waste disposal facilities. The Order is designed to ensure that all DOE radioactive waste is managed in a manner that protects the environment, worker, and public health and safety. The disposal authorization specifies the limits and conditions on construction, design, operations, and closure of a low-level waste facility. DOE Order 450.1, Environmental Protection Program, and DOE Order 5400.5, Radiation Protection of the Public and the Environment, establish requirements and standards for environmental protection programs at all DOE sites. The environmental monitoring programs will be capable of detecting changing trends in performance to allow application of any necessary corrective action before exceeding the performance objectives stated in the order. DOE Order 450.1 requires implementation of sound stewardship practices that are protective of the air, water, land, cultural, and ecological resources impacted by DOE operations. Furthermore, DOE will meet or exceed compliance with applicable environmental, public health and resource protection laws, regulations, and DOE requirements in a cost-effective way to protect members of the public and the environment against undue risk from radiation (DOE Order 5400.5). To accomplish this, DOE elements are to implement an Environmental Management System (EMS) as part of DOE's Integrated Safety Management Systems (DOE Order 450.4).

In fulfillment of these requirements, a disposal authorization statement was issued on October 25, 1999, authorizing the Hanford Site to transfer, receive, possess, and dispose of low-level radioactive waste at the 200 East Area burial grounds and the 200 West Area burial grounds. ${ }^{1}$ The disposal authorization statement constitutes approval of the performance assessment and composite analysis (Kincaid et al. 1998, 2004; Wood 2005), authorizes operation of the facility, and includes conditions that the disposal facility must meet. One of the conditions is that monitoring plans for the 200 East Area and 200 West Area low-level burial grounds (LLBG) be written and approved by the DOE Richland Operations Office (DOE-RL). The plan must meet criteria within the Radioactive Waste Management Manual (DOE M 435.1), which provides specific requirements for implementing the order. In response, a performance assessment monitoring plan (DOE-RL 2000a) for the LLBG was prepared and issued in November 2000. The DOE manual also states that a disposal authorization statement shall be issued based on a review of the facility's performance assessment and the composite analysis or appropriate Comprehensive Environmental Response, Compensation and Liability Act (CERCLA) documentation. A site-specific performance assessment and composite analysis shall be used to determine the media, locations, radionuclides, and other substances monitored. The environmental monitoring program shall be designed to include measuring and evaluating releases, migration of radionuclides, disposal unit subsidence, and changes in disposal facility and disposal site parameters that may affect long-term performance.

The purpose of this document is to describe environmental monitoring activities at the Hanford Site LLBG and to demonstrate compliance with the DOE requirements. This Performance Assessment Monitoring Plan is a revision of the initial plan released in 2000 (DOE-RL 2000b, Revision 0). The

\footnotetext{
${ }^{1}$ Memorandum from J. J. Fiore and M. W. Frei, DOE/Washington, D.C., to R. T. French, DOE/Office of River Protection, and K. A. Kline, DOE/Richland Operations Office, Disposal Authorization Statement for the Hanford Site Low-Level Waste Disposal Facilities, dated October 25, 1999.
} 
revision is necessary to update the status of environmental and operating conditions at the LLBG and to present corresponding changes to monitoring activities and strategy, where applicable. The overall goal is to acquire the appropriate data with which to demonstrate that the assumptions and predictions made in the performance assessments and composite analysis are being met (DOE Order 435.1).

Site-specific performance assessments (Wood et al. 1995; Wood 1996, 1998) and composite analysis (Kincaid et al. 1998) were conducted for the 200 East and 200 West Areas LLBGs. Subsequent performance assessment reviews are conducted annually in a report to DOE, with the primary goal of evaluating the effects of additional inventory disposed in the LLBG in the preceding year on dose and flux estimates compared to the performance objectives (Wood 2002b, 2005). Table 1.1 lists performance objectives required at LLBG and supplemental information obtain from Wood (2005).

This plan supplements and summarizes the ongoing air and groundwater monitoring programs that have existing plans and supporting descriptive material (see Section 1.2). Thus, many of the details of those monitoring efforts, which help fulfill performance assessment monitoring, are deferred to taskspecific documents and procedures.

As identified in the performance assessment (Wood et al. 1995, 1996; Wood 1998, 2002a, 2005) and composite analysis (Kincaid et al. 1998; Kincaid et al. 2004), groundwater is considered to be the most significant long-term exposure pathway and, therefore, is the primary focus of this plan.

Table 1.1. Performance Objectives for 200 East and West Area Low-Level Burial Grounds Compared with Estimates of Dose and Flux

\begin{tabular}{|c|c|c|c|c|}
\hline \multirow[b]{2}{*}{ Exposure Pathway ${ }^{(a)}$} & \multirow[b]{2}{*}{$\begin{array}{l}\text { Performance } \\
\text { Objective }^{(b)}\end{array}$} & \multicolumn{3}{|c|}{ Estimated Dose or Flux ${ }^{(\mathrm{c})}$} \\
\hline & & $\begin{array}{l}\text { Combined } 200 \text { West } \\
\text { Disposed/Projected }^{(\mathrm{d})}\end{array}$ & 218-E-10 & 218-E-12B \\
\hline All pathways & $25 \mathrm{mrem} / \mathrm{yr}$ & $0.94 / 1.1$ to 2.6 & 0.018 & 0.010 \\
\hline $\begin{array}{l}\text { Air emissions (excluding } \\
\text { radon) }\end{array}$ & $10 \mathrm{mrem} / \mathrm{yr}$ & "Nil"/not calculated & "Nil" & "Nil" \\
\hline Air emissions (radon) & $20 \mathrm{pCi} / \mathrm{m}^{2} / \mathrm{s}$ & $0.50 /$ not calculated & 0.0013 & 0.000091 \\
\hline Continuous exposure & $100 \mathrm{mrem} / \mathrm{yr}$ & $0.73 /$ not calculated & 0.0057 & 0.0032 \\
\hline Single acute exposure & $500 \mathrm{mrem} / \mathrm{yr}$ & Not listed $^{(\mathrm{e})}$ & & \\
\hline Drinking water & $4 \mathrm{mrem} / \mathrm{yr}$ & $0.18 / 0.08$ to 0.91 & 0.0066 & 0.0043 \\
\hline \multicolumn{5}{|c|}{$\begin{array}{l}\text { (a) Sources: DOE M 435.1, Radioactive Waste Management Manual; for drinking water: } 40 \text { CFR 141.66(d). } \\
\text { (b) Limits apply to the maximum exposed individual. } \\
\text { (c) From Wood (2005), Table 9, p. 21. Units of measure for estimated dose/flux are the same as for } \\
\text { Performance Objectives. } \\
\text { (d) Only } 200 \text { West Area burial grounds will continue to receive waste (as of July 2004). } \\
\text { (e) Both chronic and acute exposures were considered in the initial Performance Assessment Analyses (Wood } \\
\text { et al. 1995, 1996) but higher dose estimates resulted from chronic exposure. Hence, chronic exposure was } \\
\text { used for waste-acceptance criteria (Wood 2002b). }\end{array}$} \\
\hline
\end{tabular}




\subsection{Facilities Location and General Description}

The LLBG are located on the Hanford Site in the southeast corner of Washington State (Figure 1.1) and consist of four low-level waste management areas (LLWMA) that contain a total of seven burial grounds: $218-\mathrm{E}-10$ and 218-E-12B in the 200 East Area and 218-W-3A, 218-W-3AE, 218-W-5, 218-W-4B, and 218-W-4C in the 200 West Area. The burial grounds consist of lined and unlined disposal trenches of various sizes and depths that began receiving waste in January 1960. The low-level waste burial grounds have been grouped into four LLWMAs for Resource Conservation and Recovery Act (RCRA) groundwater monitoring purposes. A fifth LLWMA, which never received waste, was dropped from the list when it became apparent that it would not be used. The waste management areas, corresponding burial ground designation, and approximate size of each area are shown in Table 1.2. Detailed burial ground site descriptions are provided in Sections 2 and 3.

The following sections provide a brief overview of Hanford Site history, the environmental setting, burial ground locations, dose-concentration relationships from the performance assessments, and the approach used to select specific constituents of interest for inclusion in this monitoring plan. It is the intent of this plan to cite and demonstrate coordination with other existing monitoring plans that currently apply to the LLBG. This approach not only achieves efficiency in the monitoring effort, but provides avenues to peripheral information that may be of use to the interpretation of LLBG monitoring data.

\subsection{Supporting Documentation and Controls}

Since the first release of Performance Assessment Monitoring Plan for the Hanford Site Low-Level Burial Grounds (DOE-RL 2000a), numerous controls and documents have been issued that directly or indirectly pertain to the overall management of the LLBG. Some of the specific details of these are presented in the later sections of this report.

The composite analysis (Kincaid et al. 2004), currently being updated, will be the Hanford site-wide counterpart to waste site-specific performance assessments. The composite analysis is required by DOE for continued disposal authorization for low-level waste, including the LLBG, and is intended to provide an integrated prediction of potential pathways of contamination that may affect workers, public health and safety, and the environment. Beginning in 2003, DOE-RL authorized the assembly of data packages for the 2004 Composite Analysis. These data packages are being prepared to provide conceptual models and numerical input parameters for the Systems Assessment Capability (SAC, e.g., Bryce et al. 2002). The numerical simulations include modules for atmospheric data (Napier and Ramsdell 2004), waste site locations and environmental settings (Last et al. 2004a), Columbia River dynamics (Rakowski et al. 2004), vadose-zone hydrology (Last et al. 2004b), and groundwater (e.g., Cole et al. 2001). The performance assessment, composite analysis, disposal authorization statement, closure plan (Pratt and Skelly 2000), waste acceptance requirements, and monitoring plan are part of the radioactive waste management basis (DOE M 435.1). 

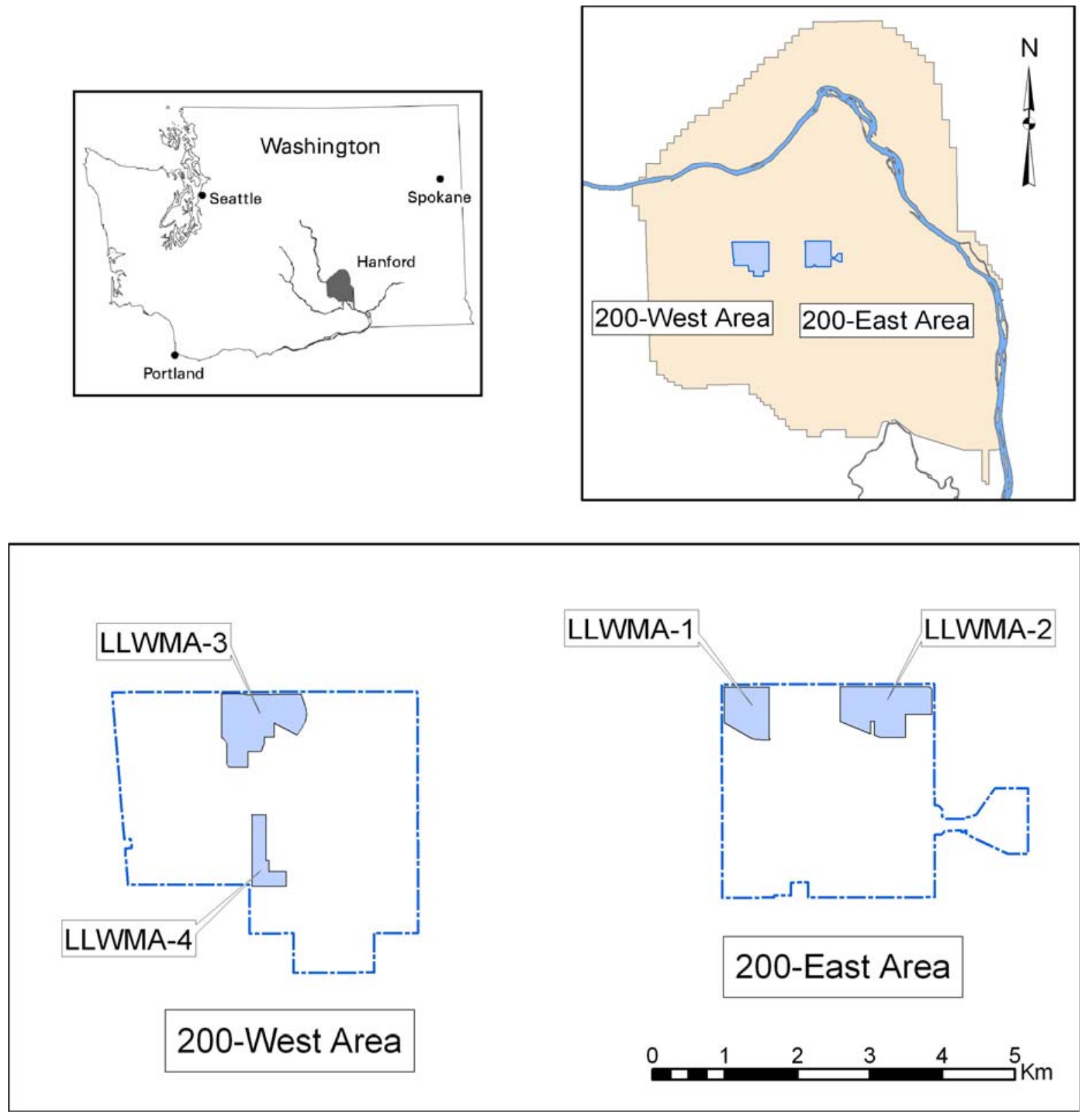

Figure 1.1. Location of 200 East and 200 West Area Low-Level Burial Grounds on the Hanford Site

Annual updates of various operational and site-wide/offsite monitoring activities, which include the LLBG, are conducted by Hanford Site contractors and Pacific Northwest National Laboratory (PNNL). The most prominent of these and the general objectives of each are:

- Hanford Site Groundwater Monitoring (e.g., Hartman et al. 2005) — an overall appraisal and results of all required groundwater monitoring for the Hanford Site for each fiscal year. Also includes summaries of groundwater and vadose zone research.

- Hanford Site Environmental Report (e.g., Poston et al. 2004) - calendar-year comprehensive report of all media and potential pathways. 
- Performance Assessment Review Reports (e.g., Wood 2005)—yearly updates of projected dose estimates due to the LLBG since September 1988 and comparisons with performance objectives. This report evaluates the effects of additional inventory and describes the basis for dose estimates (see Table 1.1).

- Radionuclide Air Emissions Report (e.g., Rokkan et al. 2005)—documents ambient radionuclide air emissions from the Hanford Site, including several sites near LLBG (see Section 5.2) as part of the Near-Facility Monitoring Program. The results are also summarized in the Hanford Site Environmental Report.

Table 1.2. LLWMAs Burial Grounds

\begin{tabular}{||c|l|c||}
\hline \hline Area & \multicolumn{1}{|c|}{ Burial Ground } & Hectares \\
\hline \hline 1 & $218-\mathrm{E}-10$ & 38.2 \\
\hline 2 & $218-\mathrm{E}-12 \mathrm{~B}$ & 70.1 \\
\hline 3 & $218-\mathrm{W}-3 \mathrm{~A}$ & 20.4 \\
& $218-\mathrm{W}-3 \mathrm{AE}$ & 20.0 \\
& $218-\mathrm{W}-5$ & 34.0 \\
\cline { 2 - 3 } & Total & 74.4 \\
\hline \multirow{3}{*}{4} & $218-\mathrm{W}-4 \mathrm{~B}$ & 3.5 \\
& $218-\mathrm{W}-4 \mathrm{C}$ & 20.9 \\
\cline { 2 - 4 } & Total & 24.4 \\
\hline \hline
\end{tabular}

The Low-Level Burial Grounds Disposal Plan (Pratt and Doughty 2002) provides requirements for disposal practices and trench use. The plan also serves as a baseline description of all the LLWMAs and associated trenches, with yearly updates to inventories and new issues appearing in the annual Performance Assessment Review Reports (Wood 2005). Requirements for acceptance, tracking, and handling of solid wastes for the LLBG are described by Fluor Hanford Waste Management Project (2005). Groundwater monitoring for RCRA requirements at the LLBG is in accordance with Dresel (2004). Because of the separate regulatory drivers for groundwater monitoring on the Hanford Site (e.g., RCRA, CERCLA, State Waste Discharge Permits, Atomic Energy Act [AEA]), efficiencies and coordination in sampling and analysis for these efforts are described and condensed in the Fiscal Year 2005 Integrated Monitoring Plan for the Hanford Groundwater Performance Assessment Project (Hartman and Rieger 2005).

Current disposal data on the LLWMAs are maintained in the Solid Waste Information Tracking System (SWITS) and the Waste Information Data System (WIDS). The types of data available in the SWITS are summarized by Fluor Hanford Waste Management Project (2002). Current information is also available from various sources on groundwater, air, and subsidence monitoring at the LLBG. The Hanford Environmental Information System (HEIS) contains data on the results of environmental media sampling on the Hanford Site, including the LLBG.

Because groundwater beneath the Hanford Site is the primary concern for contamination migration offsite and risk to the general public, this pathway is given special attention in Hanford's Groundwater Management Plan: Accelerated Cleanup and Protection (DOE-RL 2003). Here, the prime goals of groundwater protection, remediation, and monitoring are described along with the governing documents, 
priorities, and accelerated timelines for goal completion. Containment or shrinkage of contamination to the Core Zone of the 200 Areas central plateau (within which the LLBG are located) is a key aspect of Hanford groundwater management. 


\subsection{Waste Management Areas Descriptions and Histories}

Although both radioactive and chemical wastes have been placed in the burial grounds, performance assessment monitoring is limited to the radioactive component. Brief descriptions of each burial ground, including a site map showing monitoring well locations and disposal history, is presented here, with an emphasis on radioactive materials received since the last version of this document (November 2000). For greater detail, the reader is referred to Pratt and Doughty (2002) and Wood (2005).

\subsection{Status of the LLBG}

The burial grounds in LLWMAs 1-4 have historically received non-liquid radioactive and mixed waste from various onsite and offsite DOE operations and are regulated under Subtitle C, Hazardous Waste Management of RCRA and the State of Washington's Dangerous Waste Regulations (WAC 173-303). However, the use of the LLBG as a disposal facility for low-level and mixed low-level wastes has been restricted to lined trenches and the Navy reactor-compartment trench only (DOE 2004; Wood 2005). Hence, as of July 2004, only the two lined trenches in burial ground 218-W-5 (trenches 31 and 34) and the Navy reactor-compartment trench in burial ground 218-E-12B are allowed to receive waste. When the two lined trenches are filled, the LLBG will cease to operate except for reactor compartment disposal at trench 94. Remaining operational lifetime of the LLBG is dependent on waste volume disposal rates. Current disposal practices and waste inventories for active LLWMAs have been determined to be in compliance with performance objectives and DOE Order 435.1 (Wood 2005).

\subsection{LLWMA 1}

This waste management area consists of a single burial ground, 218-E-10, located in the northwestern corner of the 200 East Area. The northern portion of this area is unused. The southern portion contains a total of 13 unlined trenches with a north-south orientation and two other smaller trenches at the southeast corner with an east-west orientation. The trenches are typically V-shaped excavations $\sim 4.5$ meters deep and vary in length from $\sim 230$ to 425 meters. Trench 1 is 7.3 meters deep with a bottom width of 4.5 meters. The east-west trench is of similar construction, but is only 30.5 meters long. These unlined trenches were excavated into the natural surface materials that consist of coarse gravel, cobbles, and boulders, with some interstitial sand. Generally, these trenches are excavated with 1:1 to 1:1.5 side slopes.

\subsubsection{Disposal History}

Disposal operations at LLWMA 1 began in 1960. Waste disposed to this LLWMA comes from the Plutonium-Uranium Extraction (PUREX) Plant, B Plant, and N Reactor. The waste consists primarily of drag-off waste, failed equipment, and mixed industrial wastes (Maxfield 1979). The east-west trench contains 69 hot cell cover blocks and 4 centrifuge blocks. The tops of the bails of these blocks may be only 48 centimeters below grade. The hazardous materials disposed to this facility include lead and asbestos in unknown volumes. The radiological constituents historically disposed to LLWMA 1 include carbon-14, activation products, mixed fission products, uranium, and plutonium. This burial ground does 
not contain any retrievable transuranic (TRU) waste. Only a few small areas in one trench received postAugust 19, 1987, mixed waste. No radiological waste has been added to this burial ground since July 2000.

\subsection{LLWMA 2}

This waste management area consists of a single burial ground, 218-E-12B (Figure A.2), located in the northeastern corner of the 200 East Area. It is an active landfill that began receiving waste in 1967. The facility currently contains a total of 40 unlined trenches. The trenches run generally north-south and vary in length from 90 to 580 meters. These V-shaped trenches are excavated to a depth of $\sim 5$ meters. The burial ground also includes a large, special-purpose trench (Trench 94) for disposal of nuclear reactor compartments from decommissioned U.S. Navy vessels. Disposed reactor compartments are regulated as state-only designated mixed waste due to the presence of lead shielding. Trench 94 is a large rectangular trench excavated to a depth of 18 meters with bottom dimensions of $\sim 250$ by 100 meters. A graded ramp provides access to the trench floor.

The material excavated from the construction of the trenches is used (or will be used, in the case of trench 94) to back fill and cover the disposed waste. The excavated material consists primarily of large gravel, cobbles, boulders, and sand. Some portions of this waste management area have been covered with an additional 0.6 meter of finer-grained soil and revegetated with shallow-rooted plants.

\subsubsection{Disposal History}

Disposal operations began in 1967 at LLWMA 2 and continue to the present in the reactorcompartment trench (94) only. The majority of the waste volume in the 218-E-12B burial ground was disposed before 1987. The disposed waste has been listed as miscellaneous dry waste (Maxfield 1979). Transuranic waste is present in some of the trenches. Radiological constituents historically received include carbon-14, activation products, and plutonium. Between August 2000 and July 2004, radionuclides received by the 218-E-12B burial ground included uranium $(234,235,236,238)$, tritium, technetium-99, neptunium-237, cesium-137, and strontium-90.

\subsection{LLWMA 3}

This waste management area consists of three burial grounds: 218-W-3A, 218-W-3AE, and 218-W-5. It is located in the north-central portion of the 200 West Area. Burial ground 218-W-3A consists of 57 unlined disposal trenches that vary in length from 120 to 285 meters. Burial ground 218-W-3AE consists of eight unlined trenches that vary in length from 325 to 380 meters with bottom widths of 5 to 6 meters. A minimum of 2.5 meters of backfill has been placed over the waste. Burial ground $218-\mathrm{W}-5$ consists of 10 unlined trenches and two lined trenches. The unlined trenches are approximately 160 to 350 meters long, 4.5 to 12 meters wide, and 5 to 6 meters deep. The two lined trenches (Numbers 31 and 34) and the reactor compartment in burial ground 218-E-12B are the only portions of the LLBGs that will continue to receive waste (in effect since July 2004). The two lined trenches, constructed in 2000, are 36 meters wide at the bottom, 9.1 meters deep, and 230 meters long. 


\subsubsection{Disposal History}

Burial ground 218-W-3A began operation in 1970 and received shipments described as miscellaneous TRU and non-TRU waste from the Three Mile Island accident cleanup; irradiated fuel elements from the General Electric Company's Vallecitos, California, facility; radioactive soil from a salt waste spill (encased in concrete burial boxes); and industrial waste. Burial ground 218-W-3A has not received radiological waste since 1999 .

Burial ground 218-W-3AE was placed in operation in 1981 and received waste until July 2004. Historical waste includes miscellaneous (e.g., rags, paper, rubber gloves, disposable supplies, broken tools) and industrial waste (e.g., failed equipment, tanks, pumps, ovens, agitators, heaters, hoods, jumpers, vehicles, and accessories). Radiological wastes received include uranium (232, 233, 234, 235 , 236, 238), tritium, carbon-14, selenium-79, technetium-99, neptunium-237, cesium-137, strontium-90, and very minor amounts of nickel-63, iron-55, cobalt-60, zirconium-95, and chlorine-36.

Burial ground 218-W-5 was placed in operation in 1986. This burial ground received packaged waste materials from 200 West Area operations and other wastes from Hanford and offsite. Radiological constituents have historically consisted of mixed fission products, activation products, and TRU wastes. These have included uranium $(232,233,234,235,236,238)$, chlorine-36, carbon-14, tritium, technetium-99, iodine-129, neptunium-237, strontium-90, cesium-137, cobalt-60, manganese-54, iron-55, and nickel-63. The two lined trenches ( 31 and 34 ) in $218-\mathrm{W}-5$ are currently the only locations in the LLBG that continue to receive waste.

\subsection{LLWMA 4}

This LLWMA consists of two burial grounds, 218-W-4B and 218-W-4C, and is located in the southcentral portion of the 200 West Area. Burial ground 218-W-4B contains 13 unlined east-west-trending trenches and one east-west trench, which contains 12 concrete caissons. The eastern extension of burial ground 218-W-4C was designated for future expansion and has not received any waste. The main body of this burial ground contains 82 trenches and asphalt pads that range from 150 to 215 meters in length. The asphalt pads and trenches have been designated as retrievable storage units for TRU waste. These storage units have asphalt bottoms or fire-retardant plywood placed on the bottom. Plywood is also placed on the top of and in between the layers of the stacked waste. A layer of heavy plastic and a minimum of 1.2 meters of soil are then placed over the filled portions of the storage units.

\subsubsection{Disposal History}

Burial ground 218-W-4B began receiving waste in 1967 (Maxfield 1979) until 1990 (Pratt and Skelly 2000). This waste is described as miscellaneous solid radioactive mixed waste and was received from several sources on the Hanford Site including the 100-C, 100-N, 200 West, and 300 Areas. Waste in the northern trenches was buried before November 19, 1980. Twelve below-grade caissons at the south end of the facility contain remote-handle retrievable TRU and alpha low-level waste. Waste disposal in caissons occurred between 1969 and 1990. Two trenches are filled with retrievable TRU and TRU-mixed waste. This burial ground has not received any post-August-19, 1987, RCRA, and state-only designated mixed low-level waste. However, waste disposal in caissons is reported to have occurred between 1969 and 1990 (Pratt and Skelly 2000). 
The 218-W-4C burial ground began receiving waste in 1978 and has not received waste since July 2004. Wastes include contaminated soil from the 216-Z-9 crib and combustible and noncombustible TRU wastes. Radiological constituents consist of tritium, carbon-14, technetium-99, uranium $(233,234,235,236,238)$, strontium-90, cesium-137, and TRU wastes. Retrieval of TRU waste in barrels disposed to this burial ground is currently underway and scheduled for completion before 2030 (Pratt and Skelly 2000). 


\subsection{Environmental Setting}

The Hanford Site was established in 1943 as a U.S. government nuclear materials production facility. During its history, the site's mission has included nuclear reactor operation, storage, and reprocessing of spent nuclear fuel, and management of the associated waste generated. Present activities primarily involve waste management and environmental restoration. The inactive fuel reprocessing facilities and the radioactive waste management facilities are located in the 200 East and 200 West Areas.

\subsection{Site Geography and Demography}

The Hanford Site is located in a structural and topographic depression of the Columbia Plateau called the Pasco Basin. The northern and eastern boundaries of the site generally follow the Columbia River. The southern boundary of the site is generally bounded by the Rattlesnake Hills and by the Yakima River. The Hanford Site covers an area of 1,450 square kilometers, extending into Benton, Franklin, Grant, and Adams counties. The nearest population center consists of three small cities (Richland, Kennewick, and Pasco) situated to the southeast of the site on the Columbia River. Use of the site is institutionally controlled by DOE for national security and health and safety reasons. In 1997, DOE transferred management of the Fitzner/Eberhardt Arid Lands Ecology Reserve, a 665-square kilometer area in the western part of the site, to the U.S. Fish and Wildlife Service. In addition, the U.S. Fish and Wildlife Service manages the Wahluke Slope Area and the Saddle Mountains National Wildlife Refuge, north of the Columbia River, for DOE. In 2000, the U.S. President established the Hanford Reach National Monument at the Hanford Site (65 FR 37253). This designation is consistent with the Hanford Comprehensive Land-Use Plan Record of Decision Environmental Impact Statement (DOE-RL 1999). The LLBG are located in the 200 West and 200 East Areas, which are situated on the Central Plateau of the Hanford Site. The 200 Areas are designated as an "Industrial-Exclusive" use area and are also within the Core Zone (core of contamination concerns) of the Central Plateau (DOE-RL 2003; Kincaid et al. 2004).

\subsection{Site Climatology and Meteorology}

Meteorological and climatological data have been collected at the Hanford Meteorology Station (HMS), located between the 200 East Area and the 200 West Area, since 1945. Temperature and precipitation data have been recorded in the region since 1912. The climate of the Pasco Basin is classified as semiarid or steppe with an average rainfall of about 16 centimeters per year, nearly half of which occurs in the winter months of November through January (Hoitink et al. 2005). Summers are warm and dry with abundant sunshine. The following climatic statistics are derived from Hoitink et al. (2005).

The annual average temperature at the Hanford Site is $\sim 12^{\circ} \mathrm{C}\left(53.5^{\circ} \mathrm{F}\right)$. July is typically the warmest month with an average temperature of $25^{\circ} \mathrm{C}\left(76.6^{\circ} \mathrm{F}\right)$. January tends to be the coolest month with an average temperature of $-0.5^{\circ} \mathrm{C}\left(31.1^{\circ} \mathrm{F}\right)$. On average, 53 days per year have maxima that exceed $32.2^{\circ} \mathrm{C}$ $\left(90^{\circ} \mathrm{F}\right)$ and 23 days that reach only $0^{\circ} \mathrm{C}\left(32^{\circ} \mathrm{F}\right)$ or below.

The average annual precipitation for the HMS is $\sim 17.3$ centimeters per year ( 6.8 inches per year). December is the wettest month, receiving, on average, 2.6 centimeters (1.03 inches), and July is the driest 
month receiving, on average, only 0.53 centimeter $(0.21 \mathrm{inch})$. Total annual precipitation varied from a low of 7.6 centimeters ( 2.99 inches) in 1976 to 31.3 centimeters $(12.31$ inches) in 1995 . The average annual snowfall is 37 centimeters ( $\sim 15$ inches).

Miscellaneous weather phenomena are recorded and predicted because of the disruption potential for Hanford Site activities. Dust and blowing dust (locally resuspended) occur frequently, with blowing dust the most commonly observed. Dust and blowing dust are recorded at the HMS when horizontal visibility is reduced to 9.65 kilometers or less. The average number of days per year with dust or blowing dust is 5 . The greatest number of days with dust or blowing dust in any month was 9 in May 1980, just after the Mount St. Helens eruption. Dust and blowing dust occur most frequently between March and May and again in September and occur least frequently during November and December. A graphical representation of wind direction data for the Hanford Site in the form of wind roses is given in Figure 3.1. The wind rose data indicate that the prevailing winds of the area are from the west-northwest and secondarily from the southwest. Average wind speeds are about 10 to 15 kilometers per hour. For hours of unstable directions, wind from the west-northwest and northwest sectors occur more frequently than from the other directions.

Thunderstorm activity on or near the Hanford Site, though relatively infrequent, may pose a significant hazard to outdoor workers or equipment susceptible to damage from lightning. On average, the Hanford Site has 10 thunderstorm days per year, with July having the greatest number $(\sim 2)$.

The HMS issues Special Adverse Weather Advisories via e-mail for various phenomena that could pose a risk to Hanford Site workers or equipment. Most of these advisories are for high winds (gusts $>35 \mathrm{mph}$ ), thunderstorms, significant snow accumulation, or freezing precipitation.

\subsection{Hydrogeology}

The primary reference for the geologic interpretation specific to the LLBG is Lindsey et al. (1994). The most recent all-inclusive hydrogeologic summaries of the suprabasalt aquifer system in the 200 East Area, where LLWMA 1 and LLWMA 2 are located, are found in Williams et al. (2000). The most recent summary of the suprabasalt hydrogeology of the entire 200 West Area, including LLWMA 3 and LLWMA 4, is published in Williams et al. (2002).

The Hanford Site lies within the Pasco Basin of the Columbia Plateau. The bedrock in this region is characterized by a thick sequence of flood basalts of the Columbia River Basalt Group. These basalts have been subsequently folded and faulted, forming broad structural and topographic basins separated by asymmetric anticlines. The basalts are overlain by sediment that accumulated in the basins. The suprabasalt sediment consists primarily of

1. fluvial-lacustrine clays, sands, silts, and gravels of the Neogene-age Ringold Formation

2. the Cold Creek unit made up of alluvial, eolian, and paleosol deposits

3. Pleistocene cataclysmic flood deposits of the Hanford formation, composed of variably consolidated gravel, sand, and silt. 


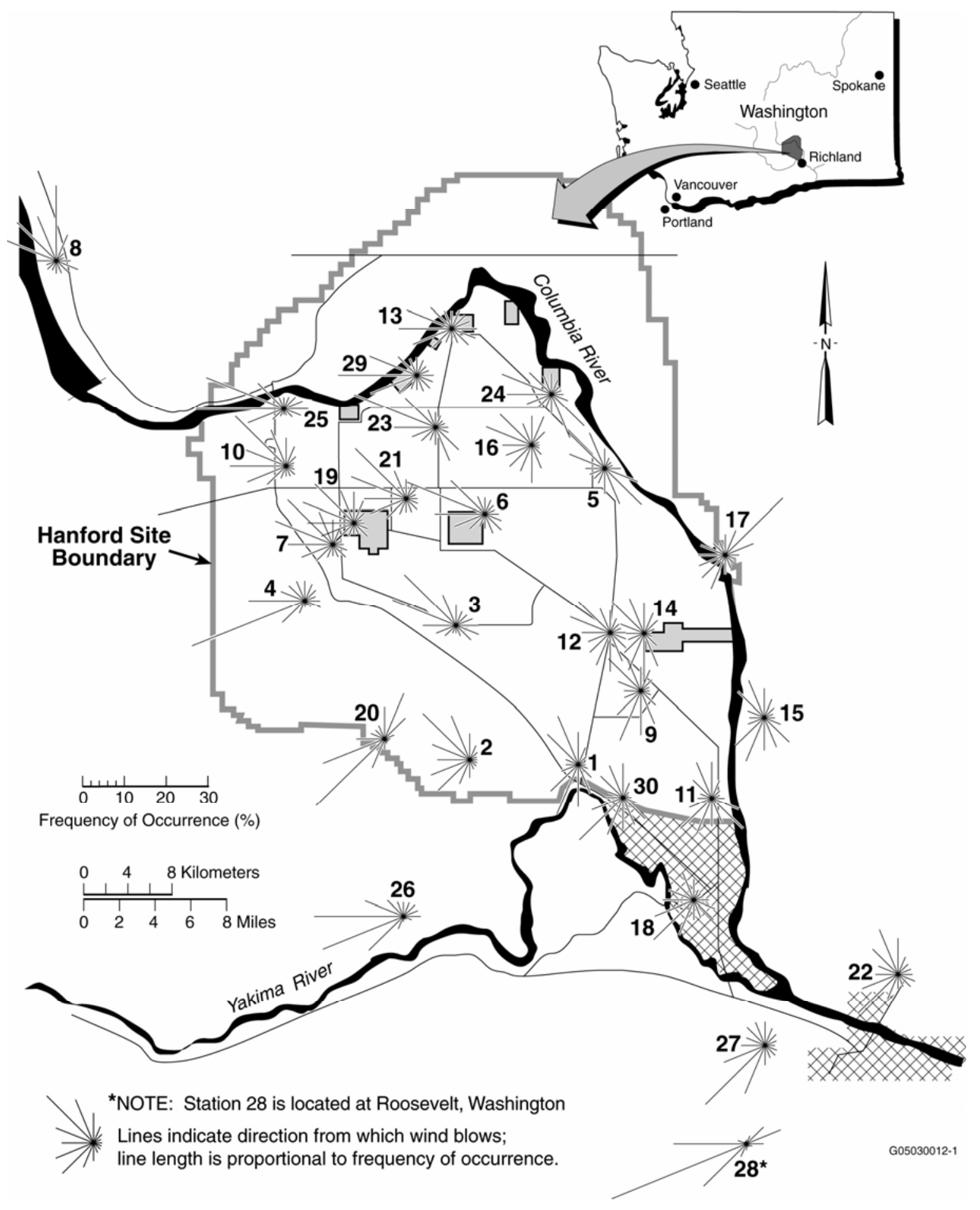

Figure 3.1. Hanford Meteorological Monitoring Network Wind Roses at 10-Meter Level, 1982 Through 2004 (from Hoitink et al. 2005) 
A thin layer of Holocene eolian and alluvial deposits of silt, sand, and gravel cover much of the Hanford Site. An updated discussion of the stratigraphy of the Hanford Site with a focus on the 200 East and 200 West Areas can be found in Reidel et al. (2005). Figure 3.2 illustrates the generalized stratigraphy of the Hanford Site.

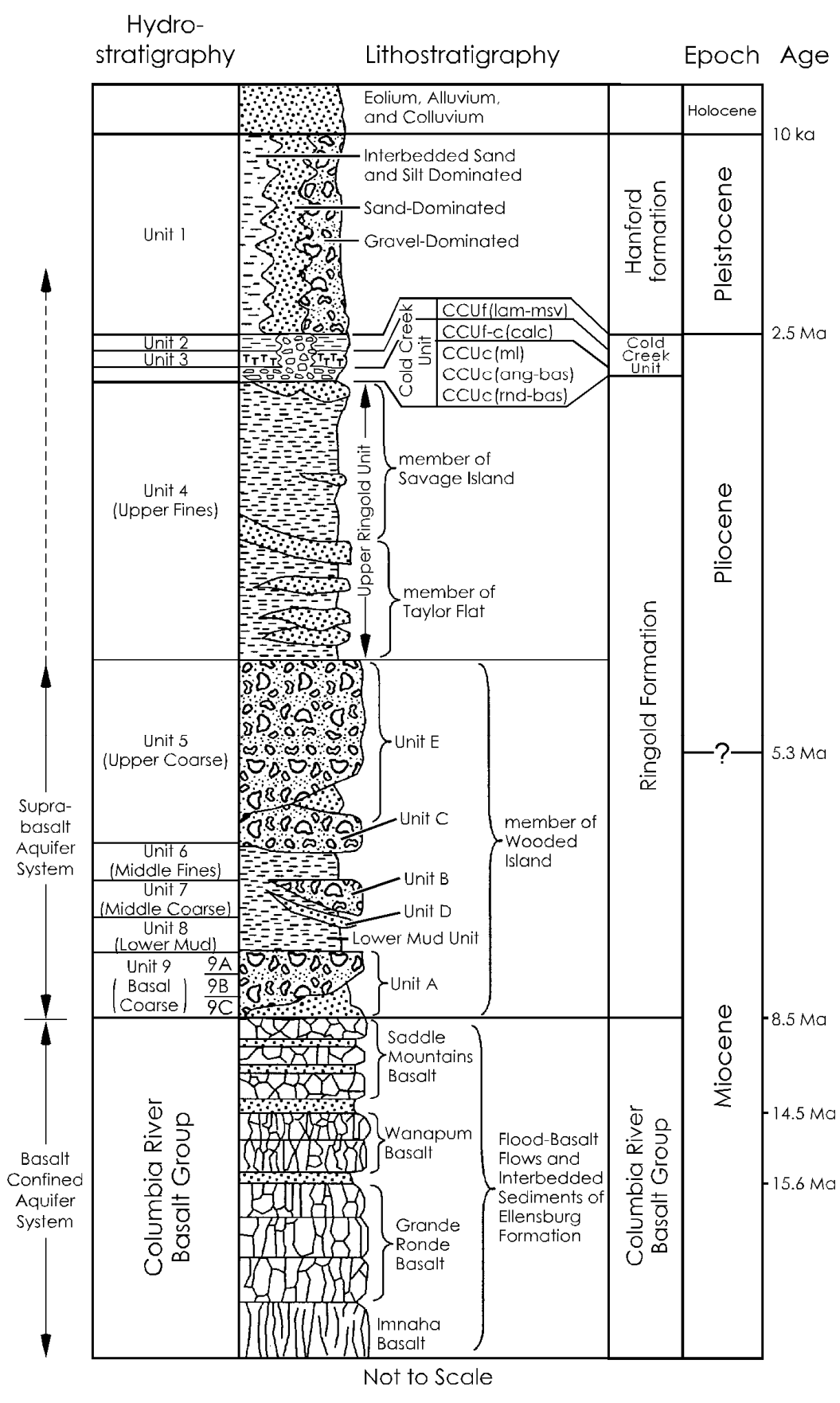

After Reidel et, al. (1992), Thorne et al. (1993), Lindsey (1995), Williams et. al. (2000), DOE (2002)

2004/DCL/HanStrat/001 (07/19)

Figure 3.2. Generalized Stratigraphy of the Hanford Site and Corresponding Hydrologic Units 
The hydrology of the Hanford Site can be divided into two major aquifer systems: the basalt (and its related interbed system) and the suprabasalt system. The basalt/interbed aquifer system is composed of a series of rubbly basalt flow tops and, where present, interbeds of sedimentary origin. These aquifers are separated by dense basalt flow interiors. The suprabasalt aquifer forms the uppermost aquifer beneath the Hanford Site. This aquifer lies in the Ringold Formation and the overlying Hanford formation. The aquifer is generally unconfined; however, there are some locally confined or semiconfined portions of the aquifer in the Ringold Formation. There are also highly localized zones of perched water in the Ringold Formation, the Cold Creek unit, and the Hanford formation.

Groundwater occurs both within the upper unconfined aquifer system and within a system of deeper confined to semiconfined aquifers in the basalt flow tops, flow bottom zones, and sedimentary interbeds. These deeper aquifers are intercalated with aquitards consisting of relatively non-porous, dense basalt flow interiors (colonnades and entablatures). The general direction of groundwater flow is from the natural recharge areas west of the Hanford Site to discharge areas, primarily toward the Columbia River.

Recharge of the confined basalt aquifers occurs through infiltration on the anticlinal ridges bounding the Pasco Basin and from westward flow in basalt aquifers beneath the Columbia Plateau. Sources of natural recharge to the uppermost-unconfined aquifer system are infiltration and runoff of precipitation and runoff on the reaches of the Yakima and Columbia Rivers. The movement of precipitation through the vadose zone has been studied at several locations on the Hanford Site (e.g., Gee 1987; Routson and Johnson 1990; Rockhold et al. 1990; Fayer et al. 1991; Gee et al. 1992; Fayer and Walters 1995; Last et al. 2004b), with the general conclusions being that very little infiltration occurs where the soil is relatively fine grained and deep-rooted vegetation is present. Where soil is coarse and vegetation is shallow rooted or absent (e.g., backfilled areas with no cap), infiltration can be considerably higher.

Artificial recharge to the uppermost aquifer occurred in the past, principally from Hanford Site contractors' wastewater disposal practices at surface facilities within the 200 East and 200 West Areas. Two of the largest recharge mounds developed beneath the 200 West and 200 East Areas at U Pond and B Pond, respectively. Discharges to U Pond, which was decommissioned in 1984, elevated the water table in excess of 26 meters after 40 years of operation. The mound under B Pond increased hydraulic head by more than 9 meters (Graham et al. 1984). These facilities were associated with wastewater disposal from fuel and waste processing activities; they received treated liquid effluents of varying chemical characteristics. Water levels in both the B Pond and U Pond areas are still declining, though discharges at these facilities were discontinued by the mid-1990s. For comparison, Figure 3.3 shows water tables in the Hanford Central Plateau in 1995 and 2005. During the intervening period between 1995 and 2005, it was determined that the Ringold Formation lower mud unit locally affected groundwater occurrence and movement more than was previously thought. Hence, this unit is shown with its interpreted effects in the 2005 water-table map.

Currently, liquid effluent (clean water) is disposed of at the 200 East Area Treated Effluent Disposal Facility. Treated effluent that includes tritium, which cannot be removed, is disposed at the StateApproved Land Disposal Site located north of the 200 West Area. Neither of these facilities have a significant effect on the water table or contamination plumes. 

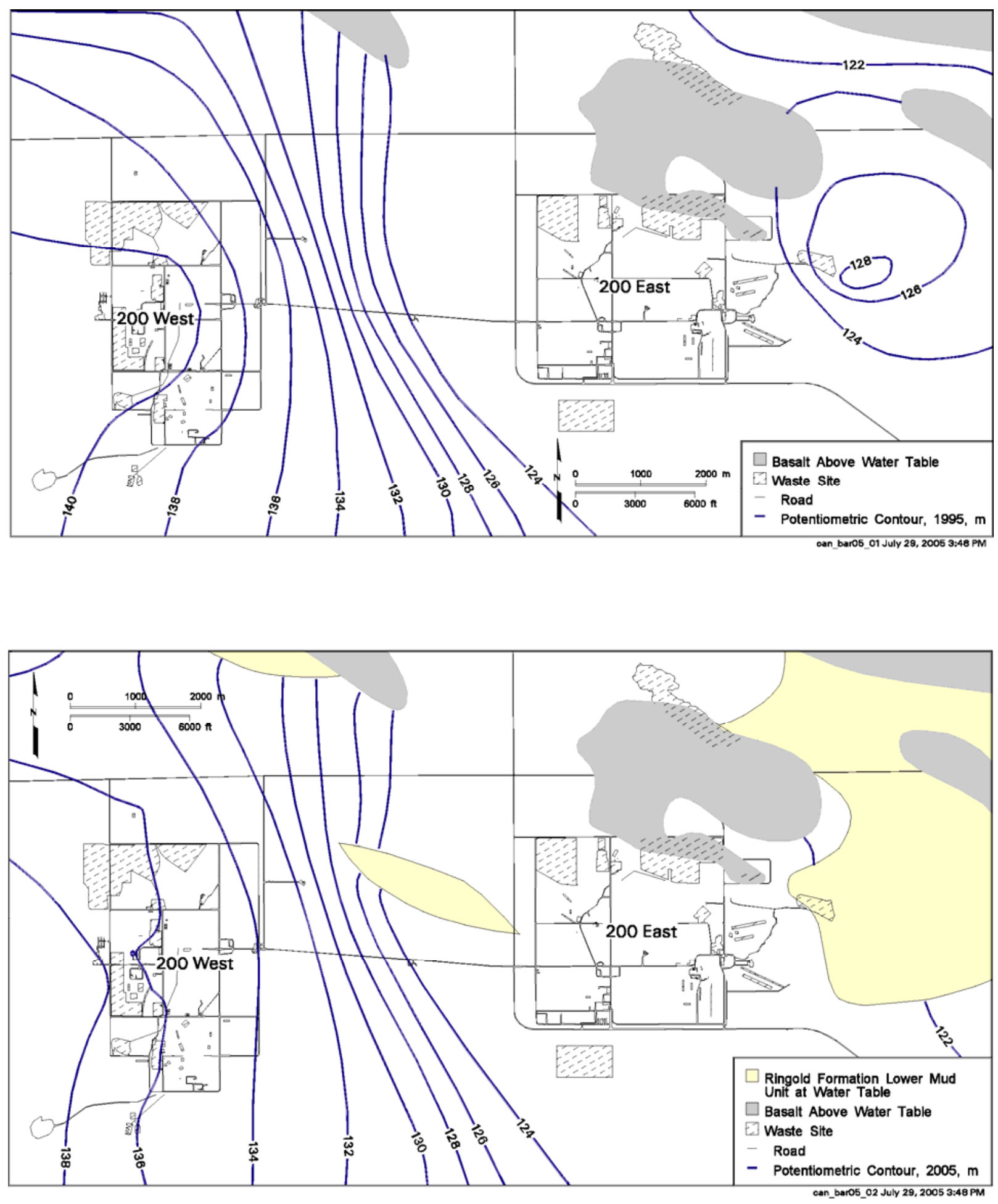

Figure 3.3. Water-Table Interpretations for 1995 (top) and 2005 (bottom) 


\subsubsection{Hydrogeology of the 200 East Area}

Data collected during the long history of drilling that has taken place in and around the 200 Areas are represented in several reports (e.g., Tallman et al. 1979; Bjornstad 1984; Last et al. 1989; Goodwin and Bjornstad 1990; Mercer 1993a, 1993b, 1994). More recent hydrogeologic interpretations of 200 East hydrogeology have been made possible by continued drilling (mostly to replace dry wells) for RCRA facilities, particularly Single-Shell Tanks Waste Management Areas A-AX and B-BY-BX. This updated information is provided by Williams et al. (2000), Wood et al. (2003), and Reidel et al. (2005).

The low-level waste burial grounds are located in the highly variable geologic setting of the 200 Areas plateau on the Hanford Site. The suprabasalt sediment in the 200 East Area consists of the Hanford and Ringold Formations. Ringold Formation sediment is generally absent beneath the northern half of this area. The Elephant Mountain Member of the Saddle Mountains Basalt is the uppermost basalt unit beneath the 200 East Area.

Groundwater flow in the 200 East Area was historically influenced by the disposal of large quantities of liquid waste to the 216-B-3 pond system (also called B Pond). A large groundwater mound that developed under B Pond essentially reversed the pre-Hanford (west to east) flow direction in the northern portion of the 200 East Area. Disposal to the B Pond system was discontinued in 1997, allowing the groundwater mound to dissipate significantly since then. The water table is entirely within the sands and gravels of the Hanford formation in the northern portion of the 200 East Area. High hydraulic conductivity and low hydraulic gradient in this area makes determination of groundwater flow direction difficult.

\subsubsection{LLWMA 1}

The suprabasalt sediment in this area consists entirely of the Hanford formation. Ringold Formation deposits are absent beneath this LLWMA, though boreholes adjacent to the BX-BY Tank Farms encountered a thin sequence of Ringold-like deposits. Data from the boreholes that reach the top of the basalt beneath the burial ground indicate the basalt dips to the west and south. The thickness of the Hanford formation in this area ranges from 70 to 100 meters. Aquifer thickness ranges from less than 2 meters in the northeast part of LLWMA 1 to $\sim 6$ meters in the southwest.

The direction of groundwater flow in this portion of the 200 East Area is difficult to determine using water-level data alone. The 2004 calculated hydraulic gradient beneath LLWMA 1 was 0.00002 . The predominant flow direction appears to be to the northwest, based on contaminant plumes movement, but this is affected by even minor, relative changes in water levels between wells (Hartman et al. 2005). Inaccuracies in water-level measurement and other uncertainties may also mask true elevation differences in head measurements.

\subsubsection{LLWMA 2}

As with LLWMA 1, the Hanford formation is the only suprabasalt unit beneath this waste management area. In this area, the Hanford formation ranges from 57 to 80 meters thick. The basalt rises above the water table in the northern part of LLWMA 2 so the unconfined aquifer is absent. The top of the basalt gently dips to the south beneath the facility. The top of the basalt represents an erosional surface, scoured by Pleistocene cataclysmic floods, and is gently undulating with enclosed depressions 3 to 
4.5 meters deep. Much deeper erosional features immediately northeast of the 200 East Area are inferred to allow intercommunication between the suprabasalt aquifer and the upper confined basalt aquifers (Graham et al. 1984; Last et al. 1989).

Groundwater flow beneath this LLWMA is predominantly east to west and has been historically influenced by liquid discharges to the B Pond system located along the eastern side of the 200 East Area. Flow direction will change as the mound from past wastewater discharges dissipates. This shift may be already underway near LLWMA 2. Groundwater flow beneath this area is further complicated by the existence of a basalt prominence that extends above the water table in the northern and eastern portions of the area. The saturated aquifer thickness ranges from 0 meters in the north and east to nearly 60 meters in the south (Hartman 2000). Hydrologic testing conducted during well construction had limited success in this area and, as at LLWMA 1 , the results were variable $(K=430$ to 2,000 meters per day and calculated flow rate of $\sim 0.04$ to $\sim 0.6$ meters per day).

\subsubsection{Hydrogeology of the 200 West Area}

The most recent summary of the suprabasalt hydrogeology in the 200 West Area, including LLWMA 3 and LLWMA 4, was published by Williams et al. (2002). Hydrogeologic reports concerning the nearby Single-Shell Tank Farm Waste Management Areas TX-TY and U provide further, up-to-date insight of subsurface conditions in the 200 West Area (e.g., Reidel et al. 2005).

The 200 West Area is underlain, from the surface to the top of the basalt, by the Hanford formation, the Cold Creek unit, and the Ringold Formation. The Cold Creek unit in this area consists mostly of carbonate-cemented alluvial and eolian facies.

Groundwater flow in the 200 West Area is also influenced by past disposal practices and by ongoing pump-and-treat systems for the 200-ZP-1 and 200-UP-1 CERCLA Operable Units. The pre-Hanford groundwater flow was predominantly west to east; however, liquid discharged to the 216-U-10 pond (also known as U Pond and decommissioned in 1984) and other disposal facilities created a substantial groundwater mound ( $\sim 26$ meters above natural level) in the southern part of the 200 West Area. This mound has since dissipated to a few meters and is still declining.

The water table beneath the entire 200 West Area is in the Ringold Formation. Perched water is possible on carbonate-rich layers in this formation and the overlying Cold Creek unit. However, because of the presence of numerous lateral discontinuities such as pinchouts and fractures, the lateral distribution of perched water (if any) is limited. The base of the unconfined aquifer beneath the 200 West Area is generally considered to be the lower mud unit of the Ringold Formation, but locally this unit (designated hydrologic unit 8) may produce confined conditions (Figure 3.2).

\subsubsection{LLWMA 3}

The saturated thickness of the uppermost aquifer beneath this waste management area is $\sim 68$ meters in the south and 78 meters in the north, where the Ringold lower mud unit is absent. The hydraulic conductivity values calculated for the wells completed in the upper portion of the unconfined aquifer varied from 2.0E-02 to 9.8 meters per day. Assuming an average effective porosity of aquifer materials 
between 0.1 to 0.3 , and a hydraulic gradient of 0.0014 , the average flow rate is thus calculated at 0.0001 to 0.14 meters per day. Flow direction is east-northeast.

\subsubsection{LLWMA 4}

The stratigraphic units beneath this area are similar to those beneath LLWMA 3. The Cold Creek unit underlies the entire area and is up to 12 meters thick, is generally thickest to the north and west, and thins to the east and south. Beneath the area, the top of the Cold Creek unit is very irregular with only a minor overall dip to the south. Perched water is possible locally on carbonate-rich layers in the unit, but because of the presence of numerous lateral discontinuities such as pinchouts and fractures, the lateral distribution of perched water probably is limited. The entire sedimentary sequence in this area ranges from 165 to 172 meters thick.

The groundwater-flow patterns beneath this LLWMA have been strongly influenced by the past and present disposal and remedial activities in the vicinity. When RCRA groundwater monitoring began in 1991, flow was east to west in the 200 West Area, with a northwest component in the northern portion of the area. Flow is now generally west to east. Further complicating the determination of groundwater flow direction is the pump-and-treat projects in the 200-ZP-1 and 200-UP-1 Groundwater Operable Units (see Hartman et al. 2005, Sections 2.8 and 2.9). The pump-and-treat systems are intended to contain the highest concentrations of the carbon tetrachloride, uranium, technetium-99, trichloroethene, and chloroform beneath the 200 West Area and to prevent further movement of these contaminants from the areas of highest concentration. Additional perturbations may occur when one of the pumping wells is shut down or new extraction wells are placed on line, as occurred in July 2004 (DOE-RL 2005). A planned shut-down of the UP-1 pump-and-treat system began in January 2005 to determine contaminant rebound properties. This system is currently expected to be restarted sometime in 2006.

The saturated thickness of the Ringold Formation above the lower mud unit varies from 68 meters at well 299-W15-17 to 75 meters at well 299-W18-22. Hydraulic conductivity for the aquifer in this area ranges from 1.5 to 33.5 meters per day. Based on an assumed effective porosity of 0.25 and a gradient of 0.003 , the average flow rate is calculated at 0.02 to 0.4 meters per day in an east to east-northeast direction.

\subsection{Groundwater Contaminant Plumes}

Past-practice disposal of wastewater to the ground resulted in extensive plumes of mobile constituents in the 200 West and 200 East Areas. Evaluation of performance assessment monitoring results for the LLBG must take into account the existing contaminant concentrations and the potential sources. Wells are considered to lie within a plume if they consistently produce concentrations of a constituent above background levels or drinking water standards and are adjacent to at least one other well with elevated levels of the constituent. Plumes of the major contaminants of concern for the 200 Areas and the LLBG, for fiscal year 2004, are shown in Appendix A and discussed here along with the most recent (March 2005) maximum concentrations. An expanded discussion of Hanford Site contaminant plumes is found in Hartman et al. (2005). 


\subsubsection{East Area}

The most significant encroachment of existing groundwater contamination is at the LLWMA 1 in the northwest corner of the 200 East Area. Most of this waste management area lies within the 1-pCi/L contour of the iodine-129 plume (see Appendix A,) and the 2,000-pCi/L contour of the tritium plume. Recent analyses indicate the highest iodine-129 activity occurs in well 299-E33-34 (3.27 pCi/L in January $2005)$ and the highest tritium activity occurs in well 299-E32-10 (18,800 pCi/L in June 2005). Technetium-99 (recently $\sim 8,000 \mathrm{pCi} / \mathrm{L}$ in well 299-33-34) also appears to cross the northeast corner of LLWMA 1. Elevated levels of uranium $(104 \mu \mathrm{g} / \mathrm{L})$, chromium $(22 \mu \mathrm{g} / \mathrm{L})$, and nitrate $(478 \mathrm{mg} / \mathrm{L})$ also occur in groundwater beneath the northeastern edge of LLWMA 1. Iodine-129 (maximum $=1.2 \mathrm{pCi} / \mathrm{L}$ ) and nitrate (maximum $=100 \mathrm{mg} / \mathrm{L}$ ) are currently the only contaminants affecting LLWMA 2 at levels above drinking water standards.

The water-table comparisons of Figure 3.3 show that the influence of the groundwater mound created by the B Pond system, just east of the 200 East Area, has lessened significantly between 1995 and 2005 . A decrease in head of greater than 4 meters in this area has occurred during this period and has further subdued an already slight hydraulic gradient in the 200 East Area. This condition has made groundwater flow determinations difficult in the 200 East Area, and hence, also hampers predictions of contaminant migration.

\subsubsection{West Area}

Groundwater beneath LLWMA 3 and LLWMA 4, in the 200 West Area, is contaminated with carbon tetrachloride from other sources (see Appendix A,). Trichloroethene occurs in the southeast corner of LLWMA 3 with a maximum value of $7.2 \mu \mathrm{g} / \mathrm{L}$ occurring in September 1995 in well 299-W10-21, but more recently, results have been $\sim 2.0 \mu \mathrm{g} / \mathrm{L}$ in the same well before it went dry. Carbon tetrachloride concentrations vary from $\sim 100 \mu \mathrm{g} / \mathrm{L}$ in the east part of the facility to below detection in the west. Carbon tetrachloride concentrations in LLWMA 4 up to $1,400 \mu \mathrm{g} / \mathrm{L}$ and trichloroethene up to $1.0 \mu \mathrm{g} / \mathrm{L}$ have been detected recently (2005) in the northeast at LLWMA 4, although the same well (299-W15-30) has historically produced concentrations as high as $\sim 7,000 \mu \mathrm{g} / \mathrm{L}$ carbon tetrachloride and $10 \mu \mathrm{g} / \mathrm{L}$ trichloroethene. Chromium has been detected at concentrations up to $20 \mu \mathrm{g} / \mathrm{L}$ beneath the extreme eastern part of LLWMA 3. Plumes of iodine-129 and technetium 99 are in the vicinity of both LLWMA 3 and LLWMA 4, but are not currently within the boundaries of these facilities. Tritium and nitrate are present in low concentration beneath both facilities. Pump-and-treat activities for the 200-UP-1 and 200-ZP-1 CERCLA Operable Units have affected, and will continue to affect, contaminant concentrations in the vicinity of LLWMAs 3 and 4.

Groundwater flow direction in the 200 West Area is gradually shifting from the north-northeast to the east (the natural or pre-Hanford flow direction). This shift is most apparent in and north of the 200 West Area (see Figure 3.3). The irregularities in head contours within the 200 West Area in 2005 are caused by the pump-and-treat activities for the 200-UP-1 and 200-ZP-1 Operable Units and by clean water disposal at the State Approved Land Disposal Site just north of the 200 West Area. In the future, after pump-andtreat activities and other artificial perturbations have ceased, the natural groundwater flow will carry the existing contamination away from the 200 West burial grounds. 


\subsection{Waste Characteristics and Conceptual Model}

A conceptual model of contaminant transport is proposed here to guide future monitoring at the LLBG. Groundwater is the primary route of potential movement of and exposure to contamination. Hence, most of the focus of this section is on the risk posed by the groundwater medium. Conceptual model assumptions for RCRA groundwater monitoring, but with implications for performance assessment monitoring, are discussed by Dresel (2004, Section 2.4). Because of the dynamic conditions at the LLBG, particularly in the 200 West Area, the model may require periodic updates or reconsideration of assumptions.

\subsection{Inventory and Constituents of Concern}

Performance assessments for the low-level waste burial grounds considered only the inventories of waste disposed after September 26, 1988, and the projected and final inventories (until closure) that are regarded as mobile in groundwater (Wood 2005). However, for purposes of the operational monitoring period, the inventories prior to September 27, 1988 must also be included. The primary radionuclides contributing to dose from groundwater contamination identified in the performance assessment and composite analysis are carbon-14, chlorine-36, iodine-129, selenium-79, technetium-99, and uranium-238. Because the mobile constituents identified in the performance assessment are the same key contaminants for both operational and post-closure conditions, the approach is to select those mobile constituents in each burial ground that would contribute most of the hypothetical groundwater pathway dose $(>99 \%)$ if breakthrough to groundwater were to occur. For this purpose, the inventories of the key mobile constituents identified in the performance assessment were taken from the closure plan (Pratt and Skelly 2000), which included the pre-1988 contributions. The total curie quantities were then divided by their corresponding derived concentration guides for drinking water (DOE Order 5400.5) to obtain relative hazard index values (see Appendix B). Constituents that contributed at least $0.1 \%$ of the total relative hazard were selected as target analytes. This approach assumes that all of the mobile constituents identified in the performance assessment have equal probability of migrating from the burial ground, and all have a distribution coefficient $\left(\mathrm{K}_{\mathrm{d}}\right)$ of zero (i.e., all are non-sorbing).

Tritium is a ubiquitous contaminant at the Hanford Site and is highly mobile in the vadose zone and groundwater. From the risk standpoint, the short half-life and travel time under Category 3 conditions reduces the dose potential of this radionuclide to an infinitesimal level (Wood et al. 1995). However, because of the usefulness of tritium as a contaminant indicator, tritium will be monitored as a constituent of concern at all burial grounds. Based on these conservative assumptions, the analytes that must be included in the monitoring program for the groundwater network are shown in Table 4.1.

Chemical uranium is monitored for the groundwater program because it is a more economical method (ultraviolet fluorescence) than alpha energy analysis. Natural abundance uranium is over $99 \%$ uranium-238 by mass. For natural abundance uranium, $20 \mu \mathrm{g} / \mathrm{L}$ of chemical uranium is equivalent to $15 \mathrm{pCi} / \mathrm{L}$ of uranium-234, uranium-235, and uranium-238 combined. 
Table 4.1. List of Radiological Constituents and Groundwater Performance Objectives for the 200 East and 200 West Areas Low-Level Burial Grounds

\begin{tabular}{||l|c|c|c|}
\hline \hline Waste Management Area & Burial Grounds & Constituent List $^{(\mathrm{a})}$ & Standard $^{(\mathrm{b})}$ \\
\hline \hline LLWMA 1 & 218-E-10 & Uranium & $30 \mu \mathrm{g} / \mathrm{L}$ \\
& & Technetium-99 & $4,000 \mathrm{pCi} / \mathrm{L}$ \\
& & Iodine-129 & $20 \mathrm{pCi} / \mathrm{L}$ \\
& & Tritium & $80,000 \mathrm{pCi} / \mathrm{L}$ \\
\hline LLWMA 2 & Uranium & $30 \mu \mathrm{g} / \mathrm{L}$ \\
& $218-\mathrm{E}-12 \mathrm{~B}$ & Technetium-99 & $4,000 \mathrm{pCi} / \mathrm{L}$ \\
& & Iodine-129 & $20 \mathrm{pCi} / \mathrm{L}$ \\
& & Tritium & $80,000 \mathrm{pCi} / \mathrm{L}$ \\
\hline LLWMA 3 & Uranium & $30 \mu \mathrm{g} / \mathrm{L}$ \\
& $218-W-3 \mathrm{~A}$ & Technetium-99 & $4,000 \mathrm{pCi} / \mathrm{L}$ \\
& 218-W-3AE & Iodine-129 & $20 \mathrm{pCi} / \mathrm{L}$ \\
& & Tritium & $80,000 \mathrm{pCi} / \mathrm{L}$ \\
\hline LLWMA 4 & Uranium & $30 \mu \mathrm{g} / \mathrm{L}$ \\
& $218-W-4 \mathrm{~B}$ & Technetium-99 & $4,000 \mathrm{pCi} / \mathrm{L}$ \\
& $218-W-4 \mathrm{C}$ & Iodine-129 & $20 \mathrm{pCi} / \mathrm{L}$ \\
& & Tritium & $80,000 \mathrm{pCi} / \mathrm{L}$ \\
\hline
\end{tabular}

(a) Constituents were derived based on relative hazard index values (see Appendix B, Tables B.1 and B.2). Tritium is included as an early warning constituent, though the relative hazard from this radionuclide is negligible.

(b) Based on DOE Order 5400.5. Concentration assumed to yield an annual dose equivalent of $4 \mathrm{mrem} / \mathrm{yr}$. For uranium, U.S. Environmental Protection Agency (EPA) final drinking water standard of $30 \mu \mathrm{g} / \mathrm{L}$ is used.

Contaminant mobility, baseline conditions, and uncertainty in the inventories are also considered in the groundwater monitoring design. Although carbon-14 was a significant percentage of the inventory in two burial ground waste management areas, it was excluded as a likely groundwater pathway contributor in LLWMA 2 because 1) carbon-14 is contained in decommissioned U.S. Navy reactor compartments that are self-contained and the source is irradiated carbon steel, and 2) in LLWMA 3, the carbon-14 is contained in concrete and not likely to leach. Also, the high carbonate content of the vadose zone should act as a sink or would at least significantly retard any carbon-14 that did leach from the burial ground.

The inventory for the 218-E-10 burial ground (LLWMA 1) shown in Appendix B lists no iodine-129. Iodine-129 is a mobile constituent with a low drinking water standard and existing groundwater contamination beneath the burial ground. For these reasons and because tracking of the iodine-129 in groundwater may help interpret flow directions, it will be monitored, consistent with the other burial grounds.

\subsection{Infiltration}

Infiltration and drainage of moisture through the vadose zone beneath the burial grounds are expected to be much greater during operations than after closure (Figure 4.1). During the operational period, runoff can accumulate in depressions and open trenches and through interim soil cover. Although unlikely, under certain conditions (e.g., an unusual precipitation event) migration to groundwater could 

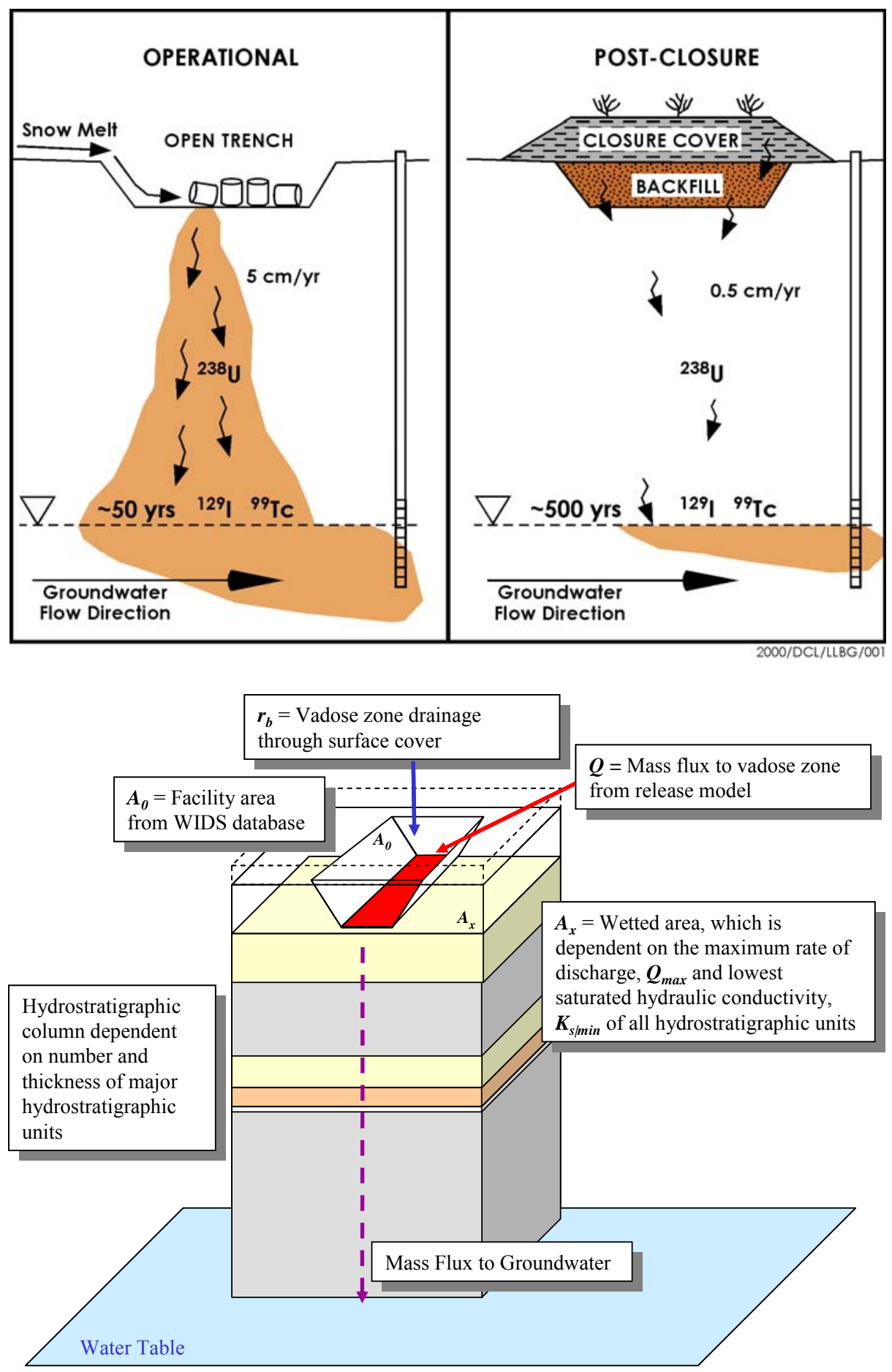

Figure 4.1. Conceptual Model of Contaminant Migration under Operational and Post-Closure Conditions (top) and Schematic of Vadose Zone Simulation Model Used for Composite Analysis (bottom, after Last et al. 2004b) 
occur in a relatively short time (estimated at 50 to 100 years in Wood et al. 1995, 1996). This is more likely in the 200 East burial grounds, where the vadose zone is in the Hanford formation (coarse sands and gravel). If breakthrough occurs during the operational period, it could indicate possible weak points in the waste management system that may need special attention for closure. During the post-closure period, the infiltration barrier would virtually eliminate such a driving force. Hence, conditions during the operational phase can be thought of as a "worst case scenario" for performance assessment.

Possible weak points in the closed facility include structural failures. Collapse of boxes and containers that have large void spaces could create depressions and openings for collection of precipitation. Such depressions and/or openings could result in localized, enhanced infiltration and shorten the travel time to groundwater considerably for some of the waste inventory. To prevent collapse or differential settling during the closure period, the bearing capacity of the waste in the trenches will be increased by methods such as repeated compaction and/or grouting of interstices (Pratt and Skelly 2000; Pratt and Doughty 2002).

Corrective action for infiltration control as well as for worker safety is accomplished by backfilling, grooming, compaction, and contouring to both avert cave-in and to minimize infiltration. As part of this plan (Pratt and Doughty 2002 — see also Section 5.4), results of the existing routine inspection program will be used to alert management to indications of potential longer-term problems that may require preventive measures to control or reduce the chance of infiltration prior to closure. Contouring to eliminate ponding of snowmelt over the covered areas of the burial grounds and encouragement of perennials to enhance evapotranspiration are longer-term preventive measures. Based on Category 3 conditions after closure, Table 4.2 indicates the estimated groundwater dose due to materials collected between September 27, 1988 (effective date of DOE Order 5820.2A) and October 31, 2004 (Wood 2005). A "Category 3 " waste site is described as having a minimum cover of 5 meters, with appropriate soil to support a mixture of deep- and shallow-rooted natural vegetation, that would limit infiltration to $0.5 \mathrm{~cm} / \mathrm{yr}(0.2 \mathrm{in} / \mathrm{yr})$ and may require immobilization of radionuclides before covering (Pratt and Skelly 2000, p. 3-5). 
Table 4.2. Category 3 Groundwater Dose Estimates (mrem/yr) by Burial Ground for Inventory Disposed September 27, 1988 to October 31, 2004 and Forecasted 2004 to Closure (after Wood 2005)

\begin{tabular}{|c|c|c|c|c|}
\hline \multirow{2}{*}{ Burial Ground } & \multirow{2}{*}{ Uranium dose } & \multicolumn{2}{|c|}{ Mobile Radionuclide Dose } & \multirow{2}{*}{ Total Dose } \\
\hline & & reported & estimated & \\
\hline & & \multicolumn{2}{|c|}{$9 / 27 / 88-7 / 31 / 03$} & \\
\hline West Area & $1.36 \mathrm{E}-01$ & $3.87 \mathrm{E}-02$ & $1.13 \mathrm{E}-02$ & $1.79 \mathrm{E}-01$ \\
\hline E10 & $1.31 \mathrm{E}-03$ & $0.00 \mathrm{E}+00$ & $5.58 \mathrm{E}-03$ & $6.63 \mathrm{E}-03$ \\
\hline \multirow[t]{2}{*}{ E12B } & $3.60 \mathrm{E}-03$ & $4.95 \mathrm{E}-05$ & $6.78 \mathrm{E}-04$ & $4.33 \mathrm{E}-03$ \\
\hline & & \multicolumn{2}{|c|}{$8 / 1 / 03-10 / 31 / 04$} & \\
\hline West Area & $7.34 \mathrm{E}-05$ & $6.65 \mathrm{E}-03$ & $6.27 \mathrm{E}-05$ & $6.78 \mathrm{E}-03$ \\
\hline E10 & $0.00 \mathrm{E}+00$ & $0.00 \mathrm{E}+00$ & $0.00 \mathrm{E}+00$ & $0.00 \mathrm{E}+00$ \\
\hline \multirow[t]{2}{*}{$\mathrm{E} 12 \mathrm{~B}$} & $1.66 \mathrm{E}-03$ & $0.00 \mathrm{E}+00$ & $4.30 \mathrm{E}-07$ & $1.66 \mathrm{E}-03$ \\
\hline & & \multicolumn{2}{|c|}{ Current Inventory Total Dose } & \\
\hline West Area & $1.36 \mathrm{E}-01$ & 4.54E-02 & $1.14 \mathrm{E}-02$ & $1.86 \mathrm{E}-01$ \\
\hline E10 & $1.31 \mathrm{E}-03$ & $0.00 \mathrm{E}+00$ & $5.58 \mathrm{E}-03$ & $6.63 \mathrm{E}-03$ \\
\hline \multirow[t]{2}{*}{ E12B } & $5.27 \mathrm{E}-03$ & 4.95E-05 & $6.79 \mathrm{E}-04$ & $5.99 \mathrm{E}-03$ \\
\hline & & \multicolumn{2}{|c|}{ Forecasted Inventory Dose* } & \\
\hline \multirow[t]{2}{*}{ West Area } & $1.31 \mathrm{E}-03$ & $0.00 \mathrm{E}+00$ & $5.1 \mathrm{E}-02$ to $8.8 \mathrm{E}-01$ & $5.2 \mathrm{E}-02$ to $8.8 \mathrm{E}-01$ \\
\hline & & \multicolumn{2}{|c|}{ Current + Forecasted Dose } & \\
\hline West Area & $1.37 \mathrm{E}-01$ & $4.54 \mathrm{E}-02$ & $6.4 \mathrm{E}-02$ to $7.2 \mathrm{E}-1$ & $2.4 \mathrm{E}-01$ to $1.1 \mathrm{E}+00$ \\
\hline E10 & $1.31 \mathrm{E}-03$ & $0.00 \mathrm{E}+00$ & $5.58 \mathrm{E}-03$ & $6.63 \mathrm{E}-03$ \\
\hline E12B & $5.27 \mathrm{E}-03$ & 4.95E-05 & $6.79 \mathrm{E}-04$ & $5.99 \mathrm{E}-03$ \\
\hline
\end{tabular}

* This projected dose assumes all future waste inventory is disposed in West Area Burial Grounds under Category 3 conditions with waste form performance including placement of future mobile radionuclide-bearing wastes (e.g.,uranium, Tc-99, Se-79, C-14 and I-129) in concrete containers. The primary mobile radionuclides providing dose in this estimated range are $1-129$ and Tc-99. 


\subsection{Monitoring}

This section describes existing air and groundwater monitoring programs, including current sampling schedules, locations, and the additional monitoring needed to meet the objectives of this supplemental plan. The existing monitoring programs will be supplemented with the constituents identified in Sections 4 (Table 4.1).

\subsection{Approach Linking Performance Assessment and Operational Monitoring}

The approach to performance monitoring for the LLBG makes use of the existing air, subsidence, and groundwater (RCRA) monitoring programs. For groundwater, the performance-related constituents of interest (uranium, technetium-99, tritium, and iodine-129) are co-sampled with the RCRA groundwater sampling schedule for the LLBG. Existing programs for air sampling and analyses and subsidence monitoring are currently adequate for performance assessment at the LLBG. Also, the results of groundwater monitoring from other programs (e.g., RCRA, CERCLA, State Waste Discharge Permit) lend insight to LLBG performance monitoring and performance review. The annual reports (see Section 1.2) are the primary means for the dissemination and review of results.

\subsubsection{Sample Media}

The primary pathways of interest are air and groundwater for both operational and post-closure conditions at the LLBG. The goals are to use the existing air and groundwater monitoring programs to the maximum extent possible. Details of the sampling and analyses of these media are provided by Hartman et al. (2002), Rieger and Hartman (2005), Duratek (2004), and PNNL (2004) for groundwater and by Perkins et al. (2003) for air sampling and analysis. The existing sampling schedules, as discussed later, are supplemented to meet the needs of the performance assessment monitoring plan where necessary. The locations of existing air and groundwater monitoring sites, and pertinent references for additional detail, are discussed in Sections 5.2 and 5.3.

\subsection{Air Pathway Monitoring}

The quality of the air is measured routinely at a large number of site-wide and offsite locations within and outside the perimeter of the Hanford Site. This network consists of two types: the Near-Facility Environmental Monitoring Program and the Surface Environmental Surveillance Program. At present, the Near-Facility Environmental Monitoring Program is managed by Fluor Hanford, Inc. whereas the Surface Environmental Surveillance Program is managed by PNNL. A description of the programs is provided in the Environmental Monitoring Plan, United States Department of Energy, Richland Operations Office (EMP, DOE-RL 2000b) and Hanford Site environment report (e.g., Poston et al. 2004).

\subsubsection{Near-Facility Environmental Monitoring Program}

Near-facility air sampling monitors are used to determine the effectiveness of the facility controls and effluent treatment systems in reducing effluents and emissions. These air samplers also measure ambient 
diffused source emissions. During 2003, a network consisting of 82 radioactivity continuous-sampling locations were used to monitor conditions across the Hanford Site (Poston et al. 2004).

A total of 43 near-facility air sampling locations were operating in the 200 East and West Areas in 2003 (Figures 5.1 and 5.2). Nineteen of these units were operated in the general vicinity of the 200 East Area LLBG, and 24 were operated in the vicinity of the 200 West Area LLBG. Both upwind and downwind monitoring locations exist around the burial grounds.

Near-facility air sampling monitors operate with a continuous flow rate of 0.056 cubic meters per minute drawing air through a 47-millimeter open-faced filter placed approximately 2 meters above the ground. The filters are exchanged biweekly, held for 1 week to allow for decay of short-lived natural radioactivity, and then sent to the analytical laboratory for analysis of total alpha and total beta activity. The gross radioactivity measurements are used to indicate changes in trends in the near-facility environment. The filters are stored until the end of either a 3- or 6-month period, then segregated and combined into composites by sample station for specific radionuclide analyses (e.g., isotopic uranium-234, -235, and -238). Specific sampling, quality assurance, and analytical procedures are described in Perkins et al. (2003) and Duratek (2000).

\subsubsection{Surface Environmental Surveillance Program}

The primary purpose of the Surface Environmental Surveillance Program is to demonstrate site-wide compliance with the EMP (DOE-RL 2000b). A key element in DOE-RL's compliance program is the Hanford Federal Facility Agreement and Consent Order (Tri-Party Agreement, Ecology et al. 1998) that brings into play all CERCLA and RCRA requirements including corrective action. In addition, the Washington State Department of Health oversees and effectively regulates the release of airborne radioactivity on the Hanford Site.

In conjunction with the Near-Facility air sampling monitoring network, a site-wide, air-monitoring program is conducted by PNNL. During 2003, the network of site-wide air monitoring consisted of 44 individual sampling units, 21 of which are located in nearby communities (Yakima, Toppenish, and Othello) or around the periphery of the Hanford Site (Figure 5.3). Samples were collected continuously, and filters were exchanged every 2 weeks. Analytes of interest included total alpha, total beta, tritium, iodine-129, and some TRU isotopes. Additional details of site-wide/offsite air sampling and analysis and results for calendar year 2003 are provided by Posten et al. (2004).

\subsection{Groundwater Monitoring}

The existing network of groundwater monitoring wells, sampling frequency, and constituents analyzed for performance assessment are listed in Appendix C. Location maps of LLWMAs 1-4 showing wells used for performance assessment and RCRA monitoring are shown in Figures C.1 through C.4. 


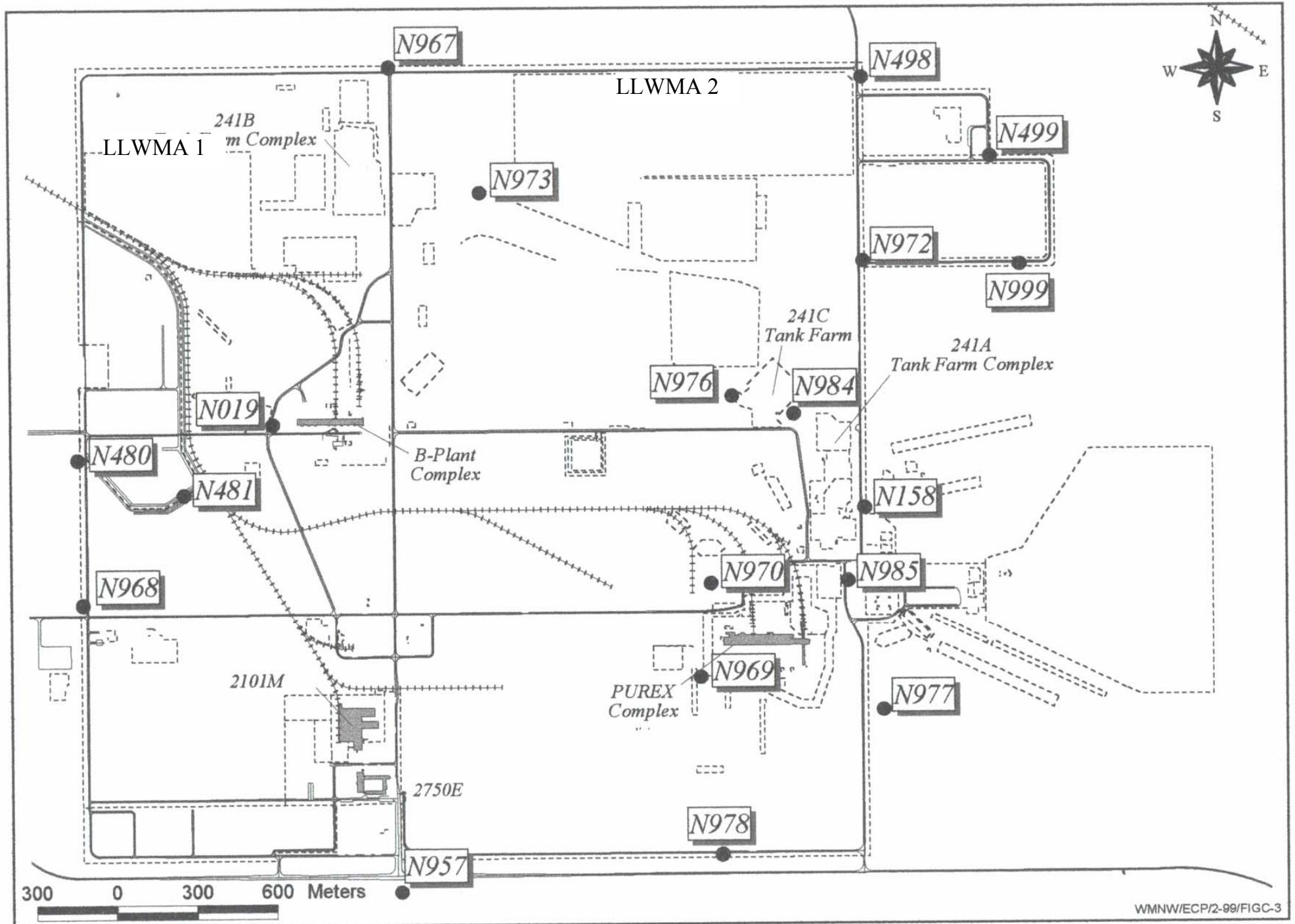

Figure 5.1. Locations of Near-Facility Air Samplers in the 200 East Area 


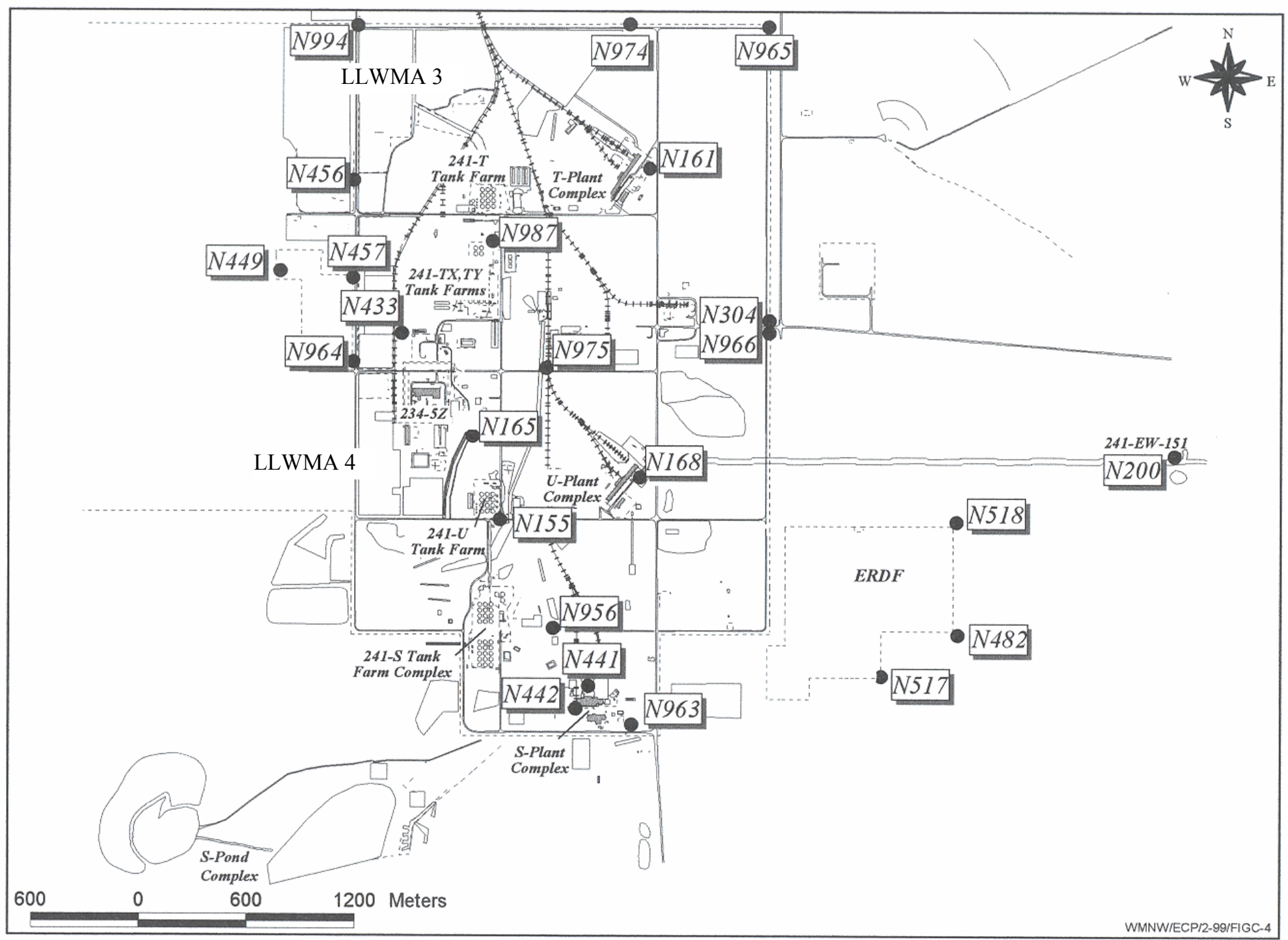

Figure 5.2. Locations of Near-Facility Air Samplers in the 200 West Area 


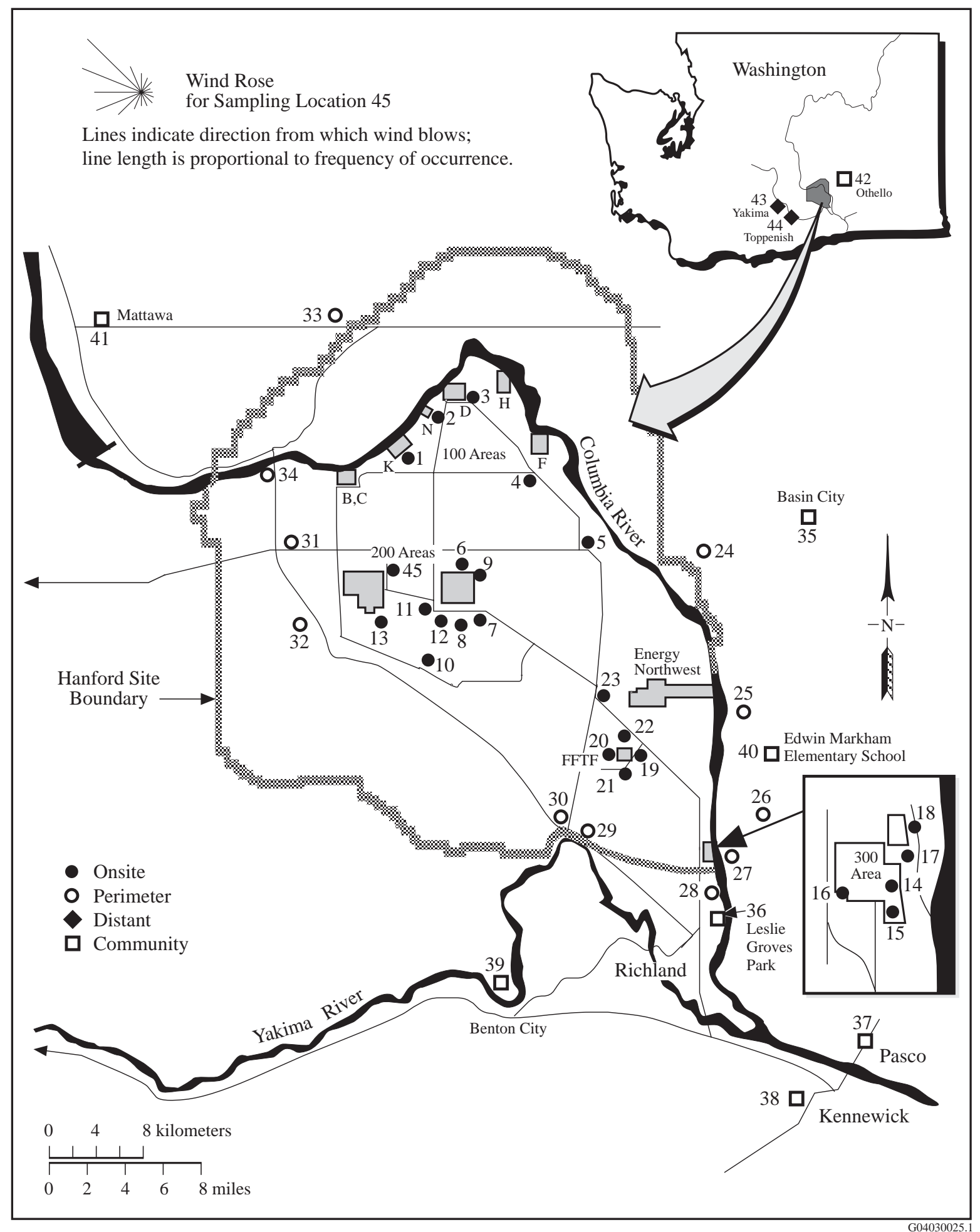

Figure 5.3. Site-Wide and Offsite Air Sampling Locations On and Near the Hanford Site 2003 (after Poston et al. 2004) 
Under the RCRA interim status monitoring, the wells are routinely sampled semiannually for the general contamination indicator parameters (specific conductance, $\mathrm{pH}$, total organic carbon, and total organic halides) and semiannually for groundwater quality and site-specific parameters except for phenol, polychlorinated biphenyls (LLWMA 2 only), mercury and lead, which are sampled annually (see Dresel 2004). The constituents of interest for this performance assessment plan (tritium, iodine-129, technetium-99, and uranium) are not analyzed for RCRA groundwater monitoring purposes (i.e., for interim status detection monitoring). However, some LLBG network wells and/or analytes are co-sampled with other monitoring that includes technetium-99 (e.g., AEA monitoring). Coordination of sampling for these overlapping priorities is described by Rieger and Hartman (2005). Sampling and analysis protocol, including chain of custody, sample collection, and analytical methods are described in Dresel (2004, Section 3.3). Sections 4.2, 5.1, and 5.2 of that document also describe the process of loading, validating, and verifying data.

As the effects of past wastewater discharges continue to dissipate, changes in the direction of groundwater flow are occurring, and the water table is declining. Eventually, the upper aquifer (above the basalt basement rock) will no longer exist beneath much of LLWMA 2. In LLWMAs 3 and 4, additional monitoring wells will be needed to adjust to the change in flow direction and to replace monitoring wells that have gone and will be going dry as the water table drops. In fulfillment of Tri-Party Agreement Milestone M-24-57, four new wells were scheduled for drilling at LLWMA 4, and three wells at LLWMA 3 during fiscal years 2005-2006 as a partial replacement for wells that have gone dry in since 2000. At least 12 additional wells are planned for drilling as a continuation of replacement wells in LLWMAs 3 and 4. No replacement wells are planned for LLWMA 2 because water levels have fallen below the top of the basalt. Replacement wells would serve no useful purpose at this site because the basalt-hosted aquifers in this area are considered isolated from any potential effects of the facility.

Periodically, it may be necessary to modify the sampling performed at the LLWMAs. Minor modifications such as changes to analytical methods (while still meeting equivalent or better performance criteria) do not require modification to this document and will be documented in the project files. Occasionally, additional samples will be collected or additional analyses performed to investigate unusual results or confirm results that exceed statistical comparison values. These additions will be documented in project files. Changes to sampling dates may occur so that co-sampling for other objectives is optimized or if scheduling or equipment problems occur. These changes will be documented in project files and quarterly and annual reports. Changes that permanently or significantly alter the monitoring under this plan will be documented via letter report or through revision of the plan.

\subsection{Subsidence Monitoring and Control}

Subsidence controls have been implemented at the low-level waste burial ground to provide operator safety and to reduce radiological risk, thereby protecting human health and the environment. Through subsidence monitoring and control, low areas that could form catchments can be identified and managed with the goal of reducing infiltration. Also, worker safety depends upon stable ground condition at the LLBG sites. 


\subsubsection{Operating Practices}

Over the years, all active LLBGs have accepted some quantity of bulk waste (e.g., contaminated vegetation and contaminated equipment) as well as packaged waste. The nature of the packaged waste varies. Packaging forms have included steel drums and boxes, wood pallets, plywood and cardboard boxes, and reinforced concrete high-integrity containers for stabilization of Category 3 waste. Drummed and boxed wastes are commonly co-mingled in many trenches. In some cases, trenches have been utilized exclusively to dispose of contact-handled or remote-handled waste. Early historical operating practices did not include a procedural requirement to segregate the various types of waste. Furthermore, the waste containers were not compacted, nor was attention given to void space that may exist in the various packages. Current disposal practices limit the amount of void space allowed (Pratt and Doughty 2002). Once the waste has been placed in the trench, the waste is covered with native soil. A minimum of 2.46 meters ( 8 feet) of soil is currently placed over disposed waste to prevent bio-intrusion, although the thickness of this cover has been as thin as 0.6 meter ( 2 feet) historically (Pratt and Skelly 2000).

\subsubsection{Inspection and Maintenance}

Until recently, no systematic effort was made to compact trench fills. In addition, the deterioration of packaging and void volume in disposed containers has been the source of some local settlement. The combined effect of these two processes has resulted in surface subsidence and, on occasion, cave-ins at some locations in the low-level waste burial grounds. Recent events at burial ground 218-W-5 (LLWMA 3) demonstrated that hazardous conditions can arise from sudden subsidence during vehicle access to the facility (e.g., Fluor Hanford Waste Management Project 2003). Between August 1, 2003 and October 31, 2004, 11 subsidence events were reported in three burial grounds (Wood 2005).

Current operating practices are attuned to each waste type and trench, as described by Pratt and Doughty (2002). As a result, weekly inspections are now performed in the burial grounds to identify locations that may require maintenance. These inspections are performed to protect the worker from injury and to ensure that if subsidence does occur, a radiation exposure pathway has not been created. All information resulting from these inspections is placed in the facility operating record as outlined in the inspection procedure. The data from these inspections are used as a basis to decide the appropriate remediation and for purposes of trend analysis. Remediation typically consists of backfilling the cave-in with native soil. The identification, recording, and backfilling (as needed) of subsidence areas have become routine activities. Low bulk density and the ongoing decomposition of waste packaging present significant long-term stability issues. Therefore, the practice of inspection and maintenance will continue throughout facility operations, facility closure, and post closure.

The inspection program can also be used to alert management to indications of longer-term drainage and settling problems. Appropriate action can be then taken to divert surface runoff away from the covered areas of the burial grounds and to minimize accumulation in open trenches. In this way, the ongoing or existing inspection program can also be used to address performance assessment monitoring and corrective action needs (e.g., to reduce or control infiltration during the operational period). 


\subsection{Data Analysis and Evaluation}

The collection and reporting of air and groundwater quality information is an integral part of the Performance Assessment Monitoring program. The overall objective for monitoring is to ensure that LLBGs are monitored for compliance with conditions of the disposal authorization statement and to verify that the LLBGs are meeting the performance objectives (see Table 1.1) of DOE Order 435.1. Specifically, the limits of $4 \mathrm{mrem} / \mathrm{yr}$ for water resource protection and the $10 \mathrm{mrem} / \mathrm{yr}$ for air emissions (excluding radon) are used to assess whether an LLBG is in compliance with DOE requirements. The following describes the general process that may be used for future comparisons for the list of radiological constituents identified in Section 4.1.

\subsection{Groundwater}

Groundwater monitoring at the Hanford Site is an integral part of the EMP (DOE-RL 2000b). This plan integrates monitoring at active waste disposal facilities to comply with requirements of RCRA and Washington State regulations with operational monitoring around nuclear facilities and environmental surveillance to comply with the EMP.

\subsubsection{Compliance with Performance Standards}

For each constituent of interest, monitoring results from compliance (downgradient) wells will be compared to the performance standards shown in Table 4.1. If an unexpected exceedance is noted, verification sampling may be conducted to see whether the exceedance is caused by errors in sampling, laboratory analysis, or transcription. Verification sampling is currently the best available approach for balancing false-positive and false-negative error rates in groundwater monitoring applications (Gibbons 1994, page 15). If results from verification sampling confirm the initial exceedance, an assessment may be conducted to determine whether the observed exceedance is likely caused by the facility or by a source(s) upgradient of the facility. The assessment could include increased monitoring at existing locations and monitoring at additional locations. If it is determined that an LLBG is the source of groundwater contamination, corrective actions may be needed to mitigate the release or potential release. In addition, based on the monitoring results, a determination of the continued adequacy of the performance assessment and composite analysis shall be made.

\subsubsection{Trend Evaluation}

To conform with the requirement that the environmental program for low-level waste disposal facilities should be capable of detecting changing trends in performance to allow any necessary corrective action before exceeding the performance objectives, trend detection will be performed on LLBG data for constituents of interest identified in Table 4.1. Several tests are available for the detection and quantification of trends. The first step in analyzing the data set, however, is to plot the concentration over time for each constituent of concern and for each well. Statistical trending methods may then be applied if appropriate. 


\subsubsection{Spatial Distribution}

Data from the performance assessment monitoring will be integrated with data from other monitoring programs to show the spatial distribution of contaminants. The spatial distribution may be represented as contour maps, as needed, where there are sufficient data. Maps of the spatial distribution provide additional information for interpreting the likely contaminant sources within a region.

\subsection{Air Pathway}

As noted previously, the Hanford EMP establishes the requirement for the environmental protection program across the Hanford Site. This program ensures that DOE operations at Hanford comply with all applicable federal, state, and local environmental laws and requirements. The collection and reporting of air quality information conducted for near-facility environmental monitoring (see Section 4.1.1) as well as site-wide/offsite monitoring (see Section 4.1.2) is an integral part of this program. Compliance will be assessed by comparison of monitoring results with the air emissions dose performance limit of $10 \mathrm{mrem} / \mathrm{yr}$ (excluding radon).

\subsubsection{Baseline}

Ambient air monitoring is conducted to determine baseline concentrations of radionuclides in the operational areas, to assess the impact of operations on the local environment, and to monitor diffuse and fugitive emissions from sources located within the operations area (i.e., near-facility air monitoring). These measurements also provide an indication of the performance of facilities managed by the Project Hanford Management Contractor and environmental restoration contractor and are used to demonstrate compliance with environmental protection criteria. Bi-weekly samples were initially collected from 40 sample locations (19 in the 200 East Area and 21 in the 200 West Area) and analyzed for total alpha and total beta activities. These initial analyses serve as an indicator of potential problems. Quarterly or semiannual composite samples were collected for other site-specific radionuclides of concern (e.g., gamma energy analysis, strontium-90, isotopic uranium). Details concerning sampling locations as well as site-specific radiological constituents are provided in Bisping (2004). The continued monitoring and reporting of time series data from composites and bi-weekly samples establishes an ongoing baseline. Average concentrations of selected radionuclides were compared to performance standards and to samples measured at a distant station (currently located at the Wye Barricade, 600 Area).

\subsubsection{Trends}

In addition to near-facility air monitoring, airborne radionuclide samples are collected at 44 continuously operating samplers: 23 on the Hanford Site, 11 near the site perimeter, 8 in nearby communities, and in the more distant communities of Yakima, Othello, and Toppenish (see Figure 5.3). Constituents of interest include gross alpha, gross beta, uranium, gamma-emitting radionuclides, tritium, and iodine-129. Average concentrations at the site perimeter were compared to the levels measured at distant stations (Yakima and Toppenish) based on a two-tailed t-test at 5\% significant level. Data from these stations are regarded as background conditions. In addition, airborne concentrations obtained from samples collected in the current year (e.g., calendar year 2003) in the near-facility areas of the Hanford Site are compared to results collected during the previous years (e.g., calendar years 1998 through 2002). Trends would be revealed through these comparisons. 


\subsubsection{Compliance with Performance Objectives}

Information from the Near-Facility air monitoring program is provided to PNNL annually for inclusion in the Hanford Site Environmental Report. PNNL uses this information to calculate offsite dose to the maximum exposed individual (MEI). Comparison of these results to the performance objectives is believed to provide a reasonable health risk estimate from the operation and disposal of radioactivity in the 200 East and 200 West Areas LLBG. For example, during 2003, the dose from all operations in the 200 Areas at the MEI was calculated to be $1.5 \times 10^{-4} \mathrm{mrem} / \mathrm{yr}$ (see Poston et al. 2004, Table 5.0.1) compared to the LLBG air pathway performance objective of $10 \mathrm{mrem} / \mathrm{yr}$.

\subsection{Corrective Action}

The corrective action policy for exceeding the performance objective will be addressed by DOE-RL. The policy for corrective action, as it relates to any non-compliance associated with the disposal authorization, will be addressed within the context of DOE Order 5400.5, Radiation Protection of the Public and the Environment, and DOE Order 435.1, Section IV, R.3.C. 


\subsection{Quality Assurance and Quality Control}

Quality assurance (QA) and quality control (QC) practices encompass all aspects of Hanford Site environmental monitoring and surveillance programs. Samples are collected and analyzed according to documented standard analytical procedures. Analytical data quality is verified by a continuing program of internal laboratory QC, participation in inter-laboratory crosschecks, replicate sampling and analysis, submittal of blind standard samples and blanks, and splitting samples with other laboratories. More detailed descriptions of the air and groundwater QA/QC program can be found in the annual reports of the groundwater program (e.g., Hartman et al. 2005), the groundwater monitoring plan for the LLBG (Dresel 2004), the annual Hanford Site Environmental Report (e.g., Poston et al. 2004) and the Groundwater Performance Assessment Project Quality Assurance Plan (PNNL 2005). The groundwater report, which includes QC results and a description of the program, is available on the Internet (http://groundwater.pnl.gov/reports/gwrep04/start.htm).

Additional quality assurance is provided by the DOE's Consolidated Audit Program (DOECAP), an organization that conducts audits of analytical laboratories and commercial mixed waste and low-level waste treatment, storage, and disposal facilities (TSDFs) that have contracts or agreements to perform services for DOE programs. DOECAP uses a formalized multi-checklist audit process with trained and qualified auditors to perform audit functions. These audit teams are composed of auditors from various contractor facilities across the DOE complex. Approximately 33 laboratories and 6 TSDFs are certified by DOECAP including 3 laboratories that perform industrial hygiene analyses.

\subsection{Groundwater Quality Assurance and Control}

Severn Trent Laboratories, Inc. currently analyzes all routine groundwater samples for the Hanford Site Groundwater Performance Assessment Project. The vendor operates under contract through Fluor Hanford, Inc. with technical oversight also provided by PNNL. PNNL audits internal and external QA/QC programs and monitors performance with blind spikes, replicates, and audits. The groundwater project's QA/QC program is described in The Groundwater Performance Assessment Project Quality Assurance Plan (PNNL 2005), which provides the quality assurance guidelines followed by the groundwater project. The QA Plan is based on the QA requirements of DOE Order 414.1A, Quality Assurance, and 10 CFR 830, Subpart A-General Provisions/Quality Assurance Requirements as delineated in PNNL's Standards-Based Management System. In addition, the groundwater project is subject to the Environmental Protection Agency (EPA) Requirements for Quality Assurance Project Plans (EPA/240/B-01/003, QA/R-5). The groundwater project has determined that the Hanford Analytical Services Quality Assurance Requirements Documents (HASQARD, DOE-RL 1998) apply to portions of the groundwater project and to the subcontractors. Details of QA/QC results for groundwater sampling and analysis each fiscal year are provided in the annual groundwater report (e.g., Hartman et al. 2005, Appendix C).

\subsection{Air Quality Assurance and Control}

This program complies with DOE Order 414.1A, and uses as its basis, standards from the American Society of Mechanical Engineers (ASME 1997), PNNL's Standards-Based Management System (for sitewide and offsite monitoring only), the HASQARD, relevant elements of ASME (1997), and recognized 
industry standards (e.g., EPA, American Society for Testing and Materials, American National Standards Institute). The Near-Facility Environmental Monitoring Program is subject to the QA requirements specified in the HASQARD, (DOE-RL 1998). Site-wide and offsite air monitoring (conducted by PNNL) QA requirements are described most recently in Hanford Site Environmental Report for Year 2004 (Poston et al. 2005; Chapter 8.18)

Actual, annual QA/QC results for air sampling are presented as part of the annual Hanford Site Environmental Surveillance Data Report, the most recent of which are found in Bisping (2004). During that period (fiscal year 2003), only two spikes for technetium-99 and one for total uranium were found to be in the "unacceptable" category. 


\subsection{Roles and Responsibilities}

This section defines the roles of the various parties involved in collection of the air, groundwater, and subsidence data and indicates how the plan will be implemented. Responsibilities for conducting sampling and analysis of media are described in Rieger and Hartman (2005) and Poston et al. (2004). Currently, PNNL collects, analyzes, and reports all groundwater and site-wide/offsite air-monitoring data for the LLBG. Near-Facility air monitoring is currently conducted by Fluor Hanford, Inc. and Duratek Federal Services Northwest, Inc.

\subsection{Reporting}

A flow diagram summarizing the collection and reporting of performance monitoring data is shown in Figure 8.1. All environmental data for the LLBG are stored in the HEIS database and will be summarized and formally published annually in the Hanford Site Groundwater Monitoring Report (e.g., Hartman et al. 2005) and Hanford Site Environmental Report (Poston et al. 2004). A summary letter report of the groundwater findings relevant to the performance assessment will be transmitted to Fluor Hanford, Inc. by PNNL each year. This report will address the specific items of interest for the performance assessment (e.g., statistical testing results of trends, status of monitoring network).

The air monitoring used for the performance assessment maintenance report will be summarized from the ongoing Hanford Site Environmental Report (e.g., Poston et al. 2004). This information is collected on a calendar year basis and generally released to the public during the early fall following the end of the calendar year. This information will be reviewed, and Fluor Hanford, Inc. will prepare a summary letter report on the results from near-facility air monitoring findings relevant to performance assessment. Because the groundwater reporting cycle is on a fiscal year basis, some data will be out of phase because of the different reporting periods. This is not perceived as a problem because it is the long-term trend that is of interest for performance assessment purposes. Subsidence monitoring information is summarized in the annual near-facility environmental monitoring report for the calendar year. Fluor Hanford, Inc. will compile this information, along with the groundwater and air data, for the updated performance assessment maintenance report. 


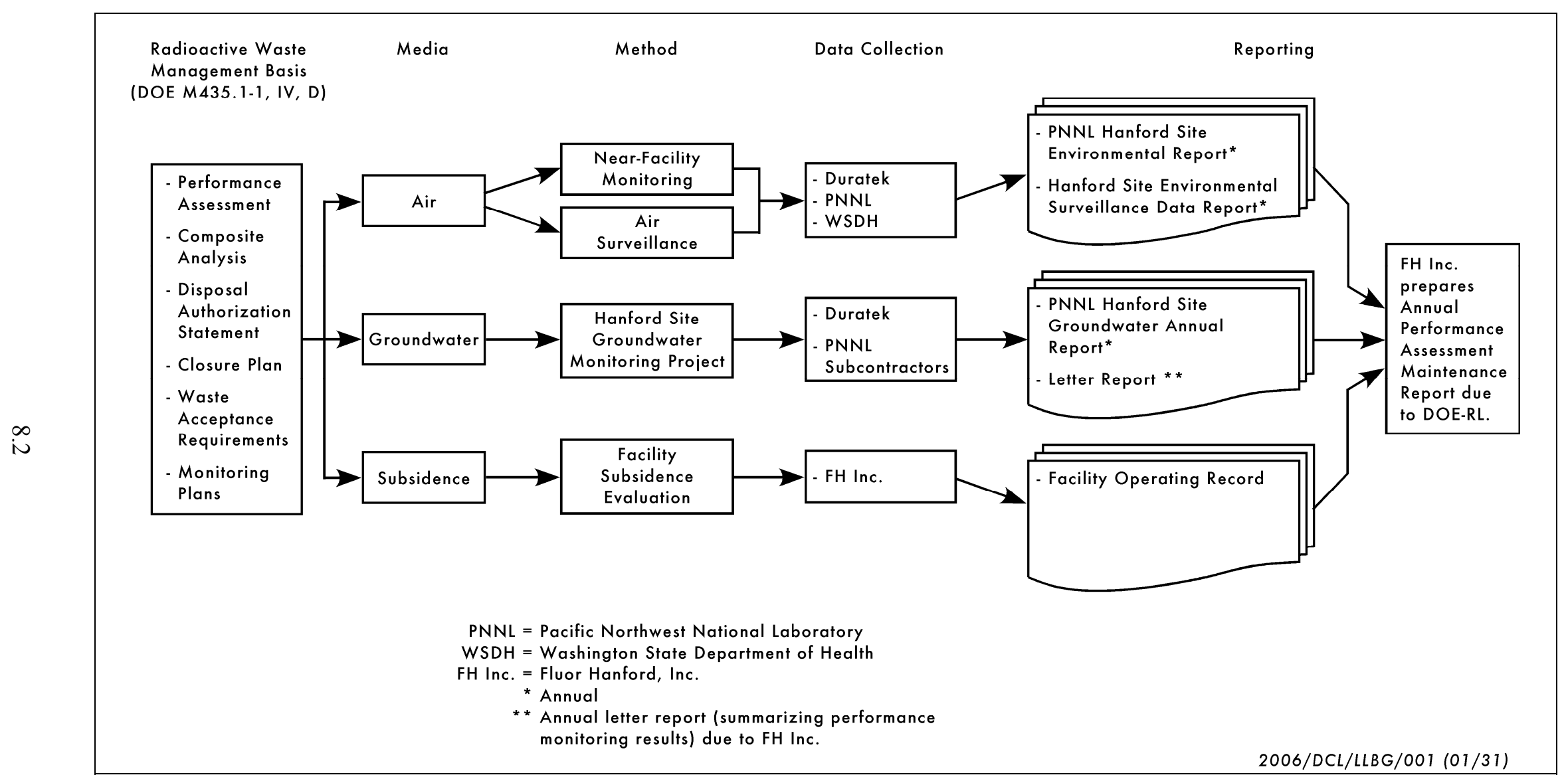

Figure 8.1. Data Collection and Reporting Road Map 


\subsection{References}

10 CFR 830. U.S. Department of Energy. "Energy/Nuclear Safety Management, Subpart A-Quality Assurance Requirements." U.S. Code of Federal Regulations.

40 CFR 141.66(d). "Maximum Contaminant Levels for Radionuclides." Code of Federal Regulations, U.S. Environmental Protection Agency.

65 FR 37253. 2000. "Establishment of the Hanford Reach National Monument." Proclamation 7319 of June 9, 2000, by the President of the United States of America. Federal Register.

ASME. 1997. Quality Assurance Program for Nuclear Facilities. ASME NQA-1-1997. American Society of Mechanical Engineers, New York, New York.

Bisping, L. E. 2004. Hanford Site Environmental Surveillance Data Report for Calendar Year 2003. PNNL-14687, APP. 1, Pacific Northwest National Laboratory, Richland, Washington.

Bjornstad, B. N. 1984. Suprabasalt Stratigraphy Within and Adjacent to the Reference Repository Location. SD-BWI-DP-039, Rockwell Hanford Operations, Richland, Washington.

Bryce, R. W., C. T. Kincaid, P. W. Eslinger, and L. F. Morasch. 2002. An Initial Assessment of Hanford Impact Performed with the System Assessment Capability. PNNL-14027, Pacific Northwest National Laboratory, Richland, Washington.

CERCLA - Comprehensive Environmental Response, Compensation, and Liability Act of 1980, as amended, Public Law 96-510, 94 Stat. 2767, 42 USC 9601 et seq.

Cole, D. R., M. P. Bergeron, C. J. Murray, P. D. Thorne, S. K. Wurstner, and P. M. Rodgers. 2001. Uncertainty Analysis Framework-Hanford Site-Wide Groundwater Flow and Transport Model. PNNL-13641, Pacific Northwest National Laboratory, Richland, Washington.

DOE. 2004. "Record of Decision for the Solid Waste Program, Hanford Site, Richland, WA: Storage and Treatment of Low-Level Waster and Mixed Low-Level Waste; Disposal of Low-Level Waste and Mixed Low-Level Waste, and Storage, Processing and Certification of Transuranic Waste for Shipment to the Waste Isolation Plant.” Federal Register, Vol. 69, No. 125, June 30, 2004.

DOE M 435.1. "Radioactive Waste Management Manual.” U.S. Department of Energy, Washington, D.C.

DOE Order 414.1A. 1999. Quality Assurance. U.S. Department of Energy, Washington, D.C.

DOE Order 435.1. "Radioactive Waste Management." U.S. Department of Energy, Washington, D.C.

DOE Order 450.1. “Environmental Protection Program.” U.S. Department of Energy, Washington, D.C.

DOE Order 450.4. “Safety Management System Policy.” U.S. Department of Energy, Washington, D.C. 
DOE Order 5400.5. "Radiation Protection of the Public and the Environment." U.S. Department of Energy, Washington, D.C.

DOE Order 5820.2A. "Radioactive Waste Management.” U.S. Department of Energy, Washington, D.C.

DOE-RL. 1999. Hanford Comprehensive Land-Use Plan Record of Decision Environmental Impact Statement. U.S. Department of Energy, Richland, Washington.

DOE-RL. 1998. Hanford Analytical Services Quality Assurance Requirements Documents. HASQARD, Volumes 1, 2, 3, and 4. DOE/RL-96-68. U.S. Department of Energy, Richland Operations Office, Richland, Washington.

DOE-RL. 2000a. Performance Assessment Monitoring Plan for the Hanford Site Low-Level Burial Grounds. DOE/RL-2000-72, Revision 0, U.S. Department of Energy, Richland, Washington.

DOE-RL. 2000b. Environmental Monitoring Plan, United States Department of Energy Richland Operations Office. DOE/RL-91-50, Rev. 0, U.S. Department of Energy, Richland, Washington.

DOE-RL. 2002. Standardized Stratigraphic Nomenclature for Post-Ringold-Formation Sediments Within the Central Pasco Basin. DOE/RL-2002-39, Rev. 0, U.S. Department of Energy, Richland Operations Office. Richland, Washington, pp. 3-1 to 3-9.

DOE-RL. 2003. Hanford's Groundwater Management Plan: Accelerated Cleanup and Protection. DOE/RL-2002-68, U.S. Department of Energy, Richland, Washington.

DOE-RL. 2005. Fiscal Year 2004 Summary Report for 200-UP-1 and 200-ZP-1 Pump-and-Treat Operations. DOE/RL-2004-72, Rev. 0, U.S. Department of Energy, Richland, Washington.

Dresel, P. E. 2004. Interim Status Groundwater Monitoring Plan for Low-Level Waste Management Areas 1 to 4, RCRA Facilities, Hanford, Washington. PNNL-14859, Pacific Northwest National Laboratory, Richland, Washington.

Duratek. 2000. Operational Environmental Monitoring. DFSNW-OEM-001, Duratek Technical Services, Richland, Washington.

Duratek. 2004. Sampling Services Procedures Manual. DTS-SSPM-001, Duratek Federal Services Northwest, Inc., Richland, Washington.

Ecology - Washington State Department of Ecology, U.S. Environmental Protection Agency, and U.S. Department of Energy. 1998. Hanford Federal Facility Agreement and Consent Order. Document No. 89-10, Rev. 5 (The Tri-Party Agreement), Olympia, Washington.

EPA/240/B-01/003 (QA/R-5). 2001. EPA Requirements for Quality Assurance Project Plans. U.S. Environmental Protection Agency, Washington, D.C. 
Fayer, M. J., M. L. Rockford, and G. W. Gee. 1991. "Recharge Potential of a Sandy Soil, EOS." Transactions of the American Geophysical Union 72:1074.

Fayer, M. J. and T. B. Walters. 1995. Estimated Recharge Rates at the Hanford Site. PNL-10285, Pacific Northwest Laboratory, Richland, Washington.

Fluor Hanford Waste Management Project. 2002. SWITS Data Entry for Waste. WMP-370, Waste Services Procedure, Section 5.1, Rev. 10, Fluor Hanford, Inc., Richland, Washington.

Fluor Hanford Waste Management Project. 2003. Occurrence Report-Wheel of Tractor Trailer Dropped into Undetected Burial Ground Substance. RL-PHMC-SOLIDWASTE-2002-0014, Fluor Hanford, Inc., Richland, Washington.

Fluor Hanford Waste Management Project. 2005. Management of LLMW at LLBG. SW-100-144, Rev. E, Change 14, Fluor Hanford, Inc., Richland, Washington.

Gee, G. W. 1987. Recharge at the Hanford Site: Status Report. PNL-6403, Pacific Northwest Laboratory, Richland, Washington.

Gee, G. W., M. J. Fayer, M. L. Rockhold, and M. D. Campbell. 1992. "Variations in Recharge at the Hanford Site." Northwest Science 66:237-250.

Gibbons, R. D. 1994. Statistical Methods for Groundwater Monitoring, John Wiley and Sons, Inc, New York, New York, pp. 165, 175-185.

Goodwin, S. M. and B. N. Bjornstad. 1990. 200-East and 200-West Areas Low-Level Burial Grounds Borehole Summary Report. WHC-MR-0204, Westinghouse Hanford Company, Richland, Washington.

Graham, M. J., G. V. Last, and K. R. Fecht. 1984. An Assessment of Aquifer Intercommunication in the B Pond-Gable Mountain Pond Area of the Hanford Site. RHO-RE-ST-12 P, Rockwell Hanford Operations, Richland Washington.

Hartman, M. J. 2000. Hanford Site Groundwater Monitoring: Setting, Sources, and Methods. PNNL-13080, Pacific Northwest National Laboratory, Richland, Washington.

Hartman, M. J. and J. T. Rieger. 2005. Fiscal Year 2005 Integrated Monitoring Plan for the Hanford Groundwater Performance Assessment Project. PNNL-15176, Pacific Northwest National Laboratory, Richland, Washington.

Hartman, M. J., L. F. Morasch, and W. D. Webber (eds.). 2005. Hanford Site Groundwater Monitoring for Fiscal Year 2004. PNNL-15070, Pacific Northwest National Laboratory, Richland, Washington.

Hartman, M. J., P. E. Dresel, J. W. Lindberg, J. P. McDonald, D. R. Newcomer, and E. C. Thornton. 2002. Fiscal Year 2003 Integrated Monitoring Plan for the Hanford Groundwater Monitoring Project. PNNL-14111, Pacific Northwest National Laboratory, Richland, Washington. 
Hoitink, D. J., K. W. Burk, J. V. Ramsdell, and W. J. Shaw. 2005. Hanford Site Climatological Data Summary 2004 With Historical Data. PNNL-15160, Pacific Northwest National Laboratory, Richland, Washington.

Kincaid, C. T., R. W. Bryce, and J. W. Buck. 2004. Technical Scope and Approach for the 2004 Composite Analysis of Low-Level Waste Disposal at the Hanford Site. PNNL-14372, Pacific Northwest Laboratory, Richland, Washington.

Kincaid, C. T., M. P. Bergeron, C. R. Cole, M. D. Freshley, N. L. Hassig, V. G. Johnson, D. I. Kaplan, R. J. Serne, G. P. Streile, D. L. Strenge, P. D. Thorne, L. W. Vail, G. A. Whyatt, and S. K. Wurstner. 1998. Composite Analysis for Low-Level Waste Disposal in the 200 Area Plateau of the Hanford Site. PNNL-11800, Pacific Northwest National Laboratory, Richland, Washington.

Last, G. V., B. N. Bjornstad, M. P. Bergeron, D. W. Wallace, D. R. Newcomer, J. A. Schramke, M. A. Chamness, C. S. Cline, S. P. Airhart, and J. S. Wilbur. 1989. Hydrogeology of the 200 Areas Low-Level Burial Grounds- An Interim Report. PNL-6820, Pacific Northwest Laboratory, Richland, Washington.

Last, G. V., W. E. Nichols, and C. T. Kincaid. 2004a. Geographic and Operational Site Parameters List (GOSPL) for the 2004 Composite Analysis. PNNL-14725, Pacific Northwest National Laboratory, Richland, Washington.

Last, G. V., E. J. Freeman, K. J. Cantrell, M. J. Fayer, G. W. Gee, W. E. Nichols, B. N. Bjornstad, and D. G. Horton. 2004b. Vadose Zone Hydrology Data Package for the 2004 Composite Analysis. PNNL-14702, Rev. 0, Pacific Northwest National Laboratory, Richland, Washington.

Lindsey, K. A., B. N. Bjornstad, J. W. Lindberg, and K. M. Hoffman. 1992. Geologic Setting of the 200 East Area: An Update. WHC-SD-EN-TI-012, Westinghouse Hanford Company, Richland, Washington.

Lindsey, K. A. 1995. Miocene- to Pliocene-Aged Suprabasalt Sediments of the Hanford Site, SouthCentral Washington. BHI-00184, Bechtel Hanford Inc., Richland, Washington.

Lindsey, K. A., J. L. Slate, G. K. Jaeger, K. J. Swett, and R. B. Mercer. 1994. Geologic Setting of the Low-Level Burial Grounds. WHC-SD-EN-TI-290, Rev. 0, Westinghouse Hanford Company, Richland, Washington.

Maxfield, H. L. 1979. Handbook - 200 Area Waste Sites. RHO-CD-673, Vols. 1 and 2, Rockwell Hanford Operations, Richland, Washington.

Mercer, R. B. 1993a. 1991 Borehole Completion Data Package for the Low-Level Burial Grounds. WHC-SD-EN-DP-044, Rev. 0, Westinghouse Hanford Company, Richland, Washington.

Mercer, R. B. 1993b. 1992 Borehole Completion Data Package for the Low-Level Burial Grounds. WHC-SD-EN-DP-049, Rev. 0, Westinghouse Hanford Company, Richland, Washington. 
Mercer, R. B. 1994. 1993 Borehole Completion Data Package for the Low-Level Burial Grounds. WHC-SD-EN-DP-086, Rev. 0, Westinghouse Hanford Company, Richland, Washington.

Napier, B. A. and J. V. Ramsdell, Jr. 2004. Atmospheric Data Package for 2004 Composite Analysis. PNNL-14599, Rev. 0, Pacific Northwest National Laboratory, Richland, Washington.

Perkins, C. J., B. M. Markes, S. M. McKinney, R. M. Mitchell, and R. C. Roos. 2003. Hanford Site Near-Facility Environmental Monitoring Data Report for Calendar Year 2002. PNNL-14295, APP. 2, Pacific Northwest National Laboratory, Richland, Washington.

PNNL. 2004. The Groundwater Performance Assessment Project Quality Assurance Plan. PNNL-15014, Pacific Northwest National Laboratory, Richland, Washington.

Poston, T. M., R. W. Hanf, R. L. Dirkes, and L. F. Morasch (eds.). 2004. Hanford Site Environmental Report for Calendar Year 2003 (Including Some Early 2004 Information). PNNL-14687, Pacific Northwest National Laboratory, Richland, Washington.

Pratt, D. A. and J. D. Doughty. 2002. Low-Level Burial Grounds Disposal Plan. HNF-SD-WM-ES-355, Rev. 5, Fluor Hanford, Inc., Richland, Washington.

Pratt, D. A. and W. A. Skelly. 2000. Closure Plan for Active Low-Level Burial Grounds. DOE/RL2000-70, Rev. 0, U.S. Department of Energy, Richland, Washington.

Rakowski, C. L., G. R. Guensch, and G. W. Patton. 2004. River Data Package for the 2004 Composite Analysis. PNNL-14824, Pacific Northwest Laboratory, Richland, Washington.

RCRA - Resource Conservation and Recovery Act. 1976. Public Law 94-580, as amended, 90 Stat. 2795, 42 USC 6901 et seq.

Reidel, S. P., K. A. Lindsey, and K. R. Fecht. 1992. Field Trip Guide to the Hanford Site. WHC-MR0391. Westinghouse Hanford Company, Richland, Washington.

Reidel, S. P., D. G. Horton, Yi-Ju Chien, D. B. Barnett, and K. Singleton. 2005. Geology, Hydrogeology, Geochemistry, and Mineralogy Data Package. RPP-23748, Rev. 0, CH2M HILL Hanford Group, Inc., Richland, Washington.

Rokkan, D. J., D. L. Dyekman, N. A. Homan (Fluor Hanford, Inc.), K. Rhoads, and L. H. Staven (Pacific Northwest National Laboratory). 2005. Radionuclide Air Emissions Report for the Hanford Site, Calendar Year 2004. DOE/RL-2005-06, Rev 0. 2005, U.S. Department of Energy, Richland, Washington.

Routson, R. C. and V. G. Johnson. 1990. Recharge Estimates for the Hanford Site Separations Area, December 1987. WHC-EP-0142, Westinghouse Hanford Company, Richland, Washington.

Rockhold, M. L., M. J. Fayer, G. W. Gee, and M. J. Kanyid. 1990. Natural Groundwater Recharge and Water Balance at the Hanford Site. PNL-7215, Pacific Northwest Laboratory, Richland, Washington. 
Tallman, A. M., K. R. Fecht, M. J. Marratt, and G. V. Last. 1979. Geology of the Separation Areas Hanford Site, South Central Washington. RHO-ST-23, Rockwell Hanford Operations, Richland, Washington.

Thorne, P. D., M. A. Chamness, F. A. Spane, Jr., V. R. Vermeul, and W. D. Webber. 1993. ThreeDimensional Conceptual Model for the Hanford Site Unconfined Aquifer System, FY93 Status Report. PNL-8971, Pacific Northwest Laboratory, Richland, Washington.

WAC 173-303. Washington State Dangerous Waste Regulations. Washington State Department of Ecology, Olympia, Washington.

Williams, B. A., B. N. Bjornstad, R. Schalla, and W. D. Webber. 2000. Revised Hydrogeology for the Suprabasalt Aquifer System, 200-East Area and Vicinity, Hanford Site, Washington. PNNL-12261, Pacific Northwest National Laboratory, Richland, Washington.

Williams, B. A., B. N. Bjornstad, R. Schalla, and W. D. Webber. 2002. Revised Hydrogeology for the Suprabasalt Aquifer System, 200-West Area and Vicinity, Hanford Site, Washington. PNNL-13858, Pacific Northwest National Laboratory, Richland, Washington.

Wood, M. I. 1996. Addendum to the Performance Assessment Analysis for Low-Level Waste Disposal in the 200 West Area Burial Grounds. HNF-SD-WM-TI-798, Rev. 0, Rust Federal Services of Hanford, Inc. for U.S. Department of Energy, Richland, Washington.

Wood, M. I. 1998. Addendum to the Performance Assessment Analysis for Low-Level Waste Disposal in the 200 East Area Burial Grounds. HNF-2005, Rev. 0, Rust Federal Services of Hanford, Inc. for U.S. Department of Energy, Richland, Washington.

Wood, M. I. 2002a. Annual Review of the 200 West and 200 East Area Performance Assessments. HNF-7562, Rev. 0, Fluor Hanford Inc., Richland, Washington.

Wood, M. I. 2002b. History of the Low-Level Waste Burial Grounds (LLBG) Performance Assessments. Correspondence No. FH-0201994, Fluor Hanford Inc., Richland, Washington.

Wood, M. I. 2005. Performance Assessment Review Report, 2003-2004 Annual Review of the 200 West and 200 East Area Performance Assessments. Correspondence No. FH-0501152, Fluor Hanford Inc., Richland, Washington.

Wood, M. I., R. Khaleel, P. D. Rittman, A. H. Lu, S. H. Finfrock, R. J. Serne, K. J. Cantrell, and T. H. DeLorenzo. 1995. Performance Assessment for the Disposal of Low-Level Waste in the 200 West Area Burial Grounds. WHC-EP-0645, Westinghouse Hanford Company, Richland, Washington.

Wood, M. I., R. Khaleel, P. D. Rittmann, A. H. Lu, S. H. Finfrock, T. H. De Lorenzo, and D. Y. Garbrick. 1996. Performance Assessment for the Disposal of Low-Level Waste in the 200 East Area Burial Grounds. WHC-SD-WM-TI-730, Westinghouse Hanford Company, Richland, Washington. 
Wood, M. I., T. E. Jones, B. N. Bjornstad, D. G. Horton, S. M. Narbutovskih, and R. Schalla. 2003. Subsurface Conditions Description of the C and A-AX Waste Management Area. RPP-14430, Rev. 0, CH2M HILL Hanford Group, Inc., Richland, Washington. 
Appendix A

Groundwater Contaminant Plumes in the 200 West and 200 East Areas 


\title{
Appendix A
}

\section{Contamination Contaminant Plumes in the 200 West and 200 East Areas}

\begin{abstract}
Groundwater contamination plumes that exist beneath, or in the vicinity of, the Hanford low-level burial grounds (Low-Level Waste Management Areas 1-4) are shown for the 200 West (Figures A.1 through A.8) and 200 East (Figures A.9 through A.15) Areas for fiscal year (FY) 2004. Contours for the plumes are based on average concentrations or activities for all samples during FY 2004. All the maps are taken from Hartman et al. (2005). Plumes are discussed in Section 3.4 of the main document.

\section{Reference}

Hartman, M. J., L. F. Morasch, and W. D. Webber (eds.). 2005. Hanford Site Groundwater Monitoring for Fiscal Year 2004. PNNL-15070, Pacific Northwest National Laboratory, Richland, Washington. 


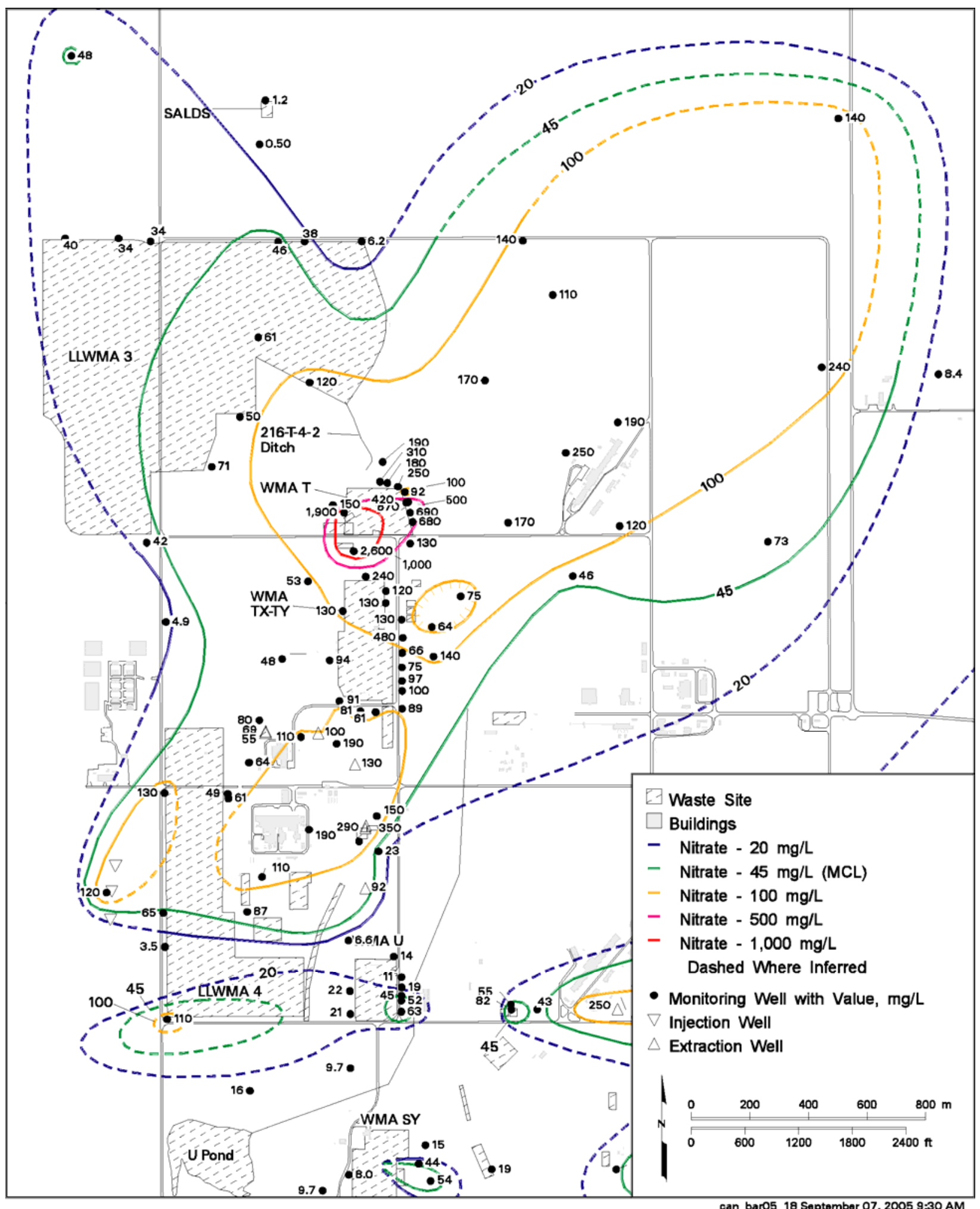

Figure A.1. Nitrate Concentrations in the 200 West Area, FY 2004 


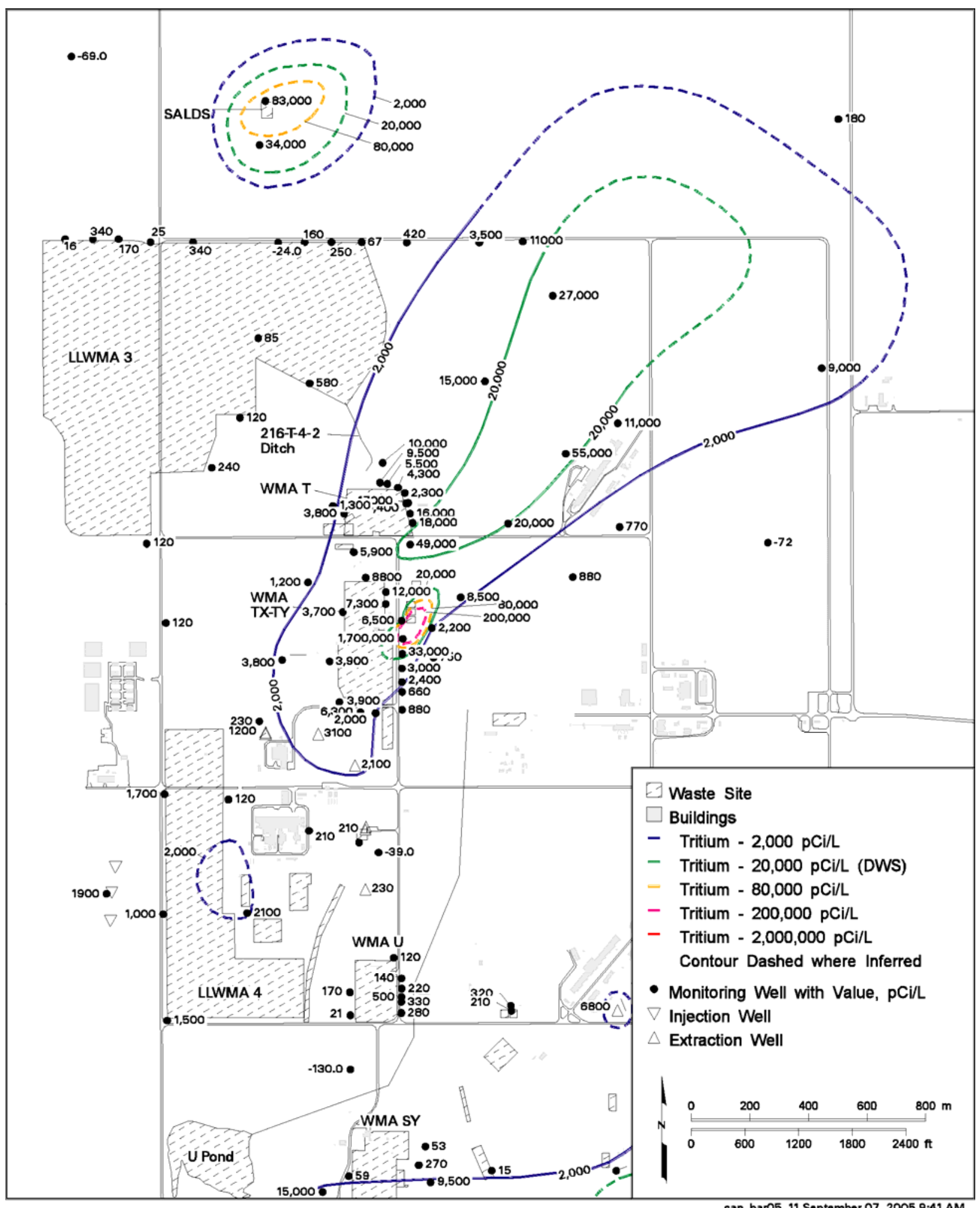

Figure A.2. Tritium Concentrations in the 200 West Area, FY 2004 


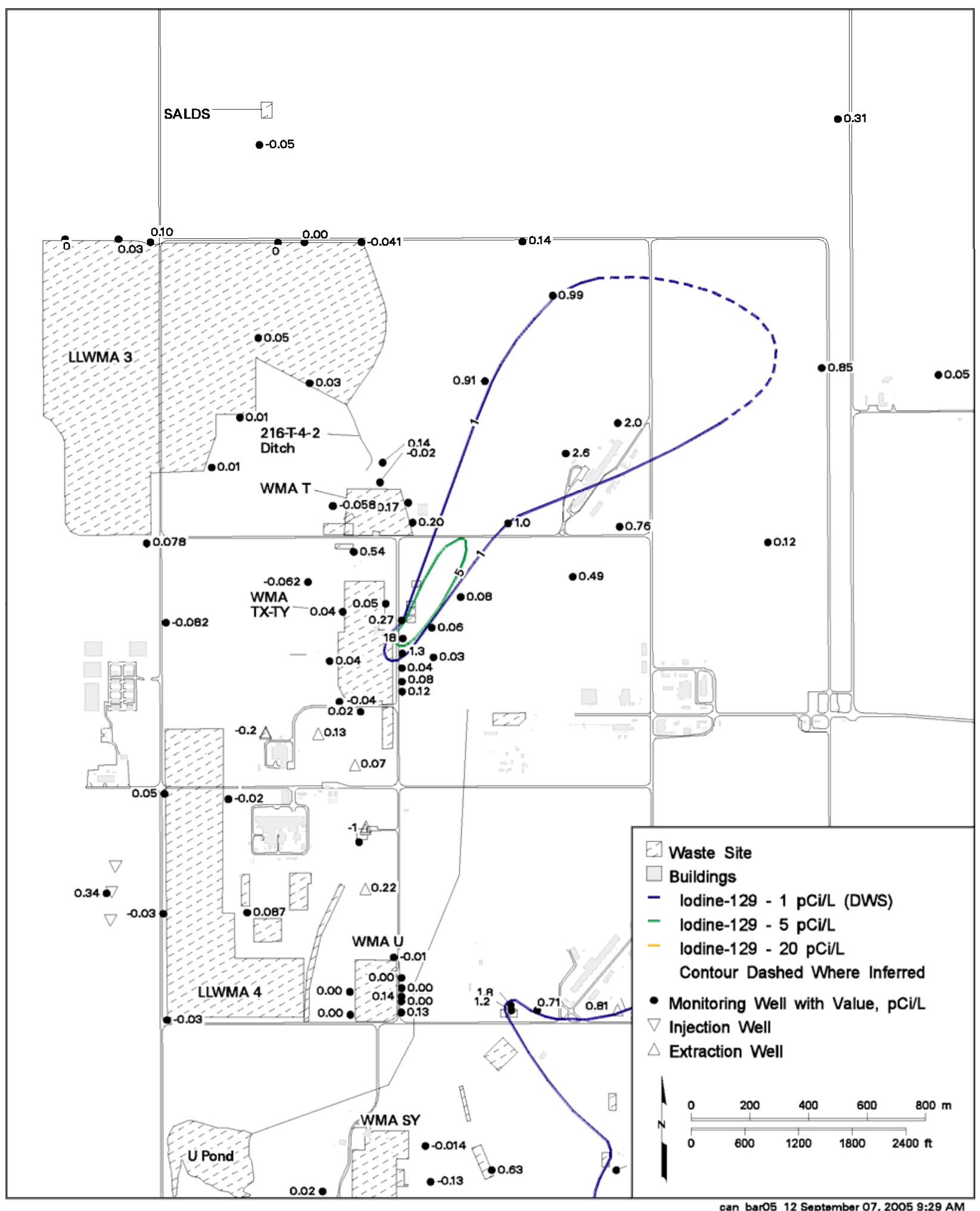

Figure A.3. Iodine-129 Concentrations in the 200 West Area, FY 2004 


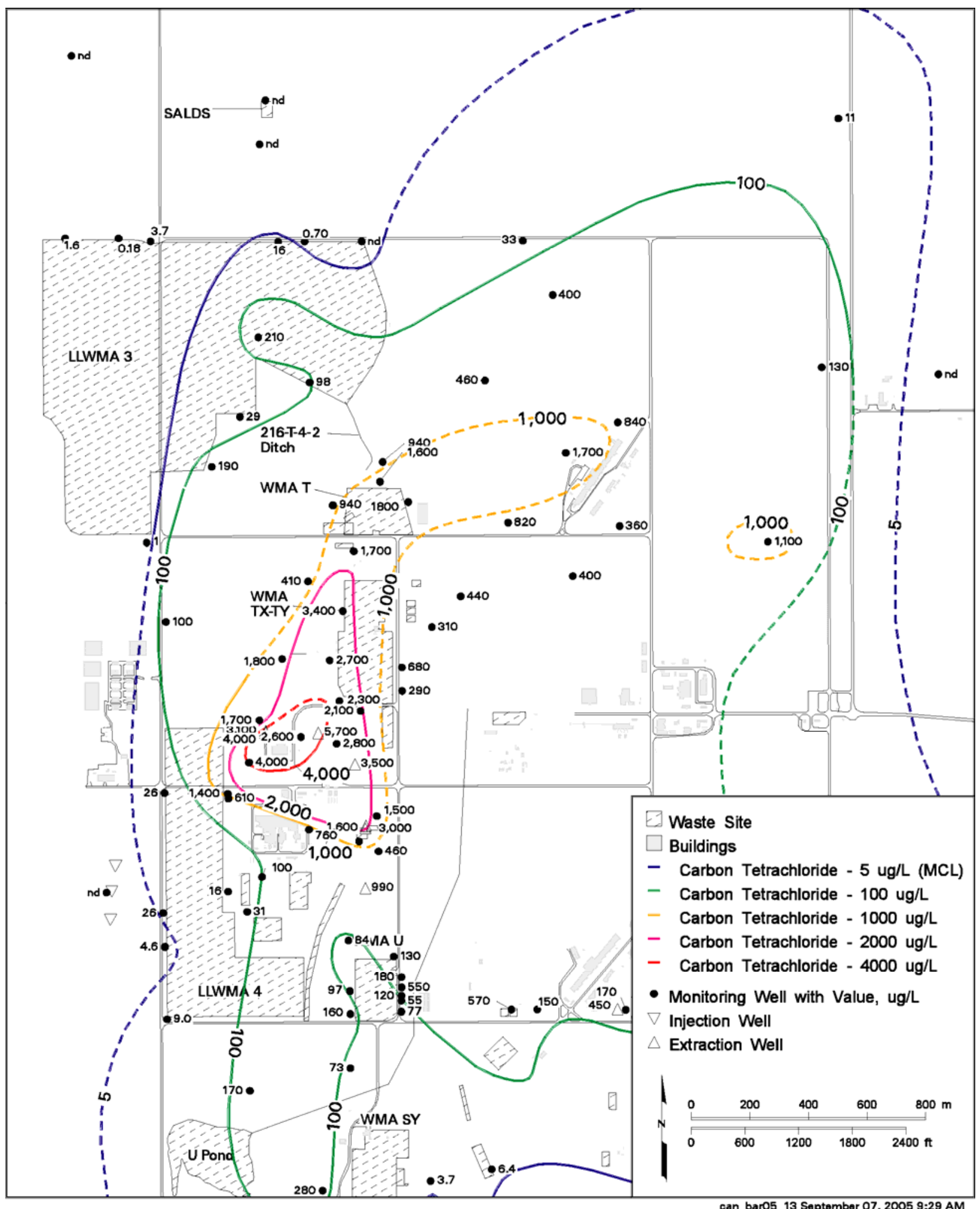

Figure A.4. Carbon Tetrachloride Concentrations in the 200 West Area, FY 2004 


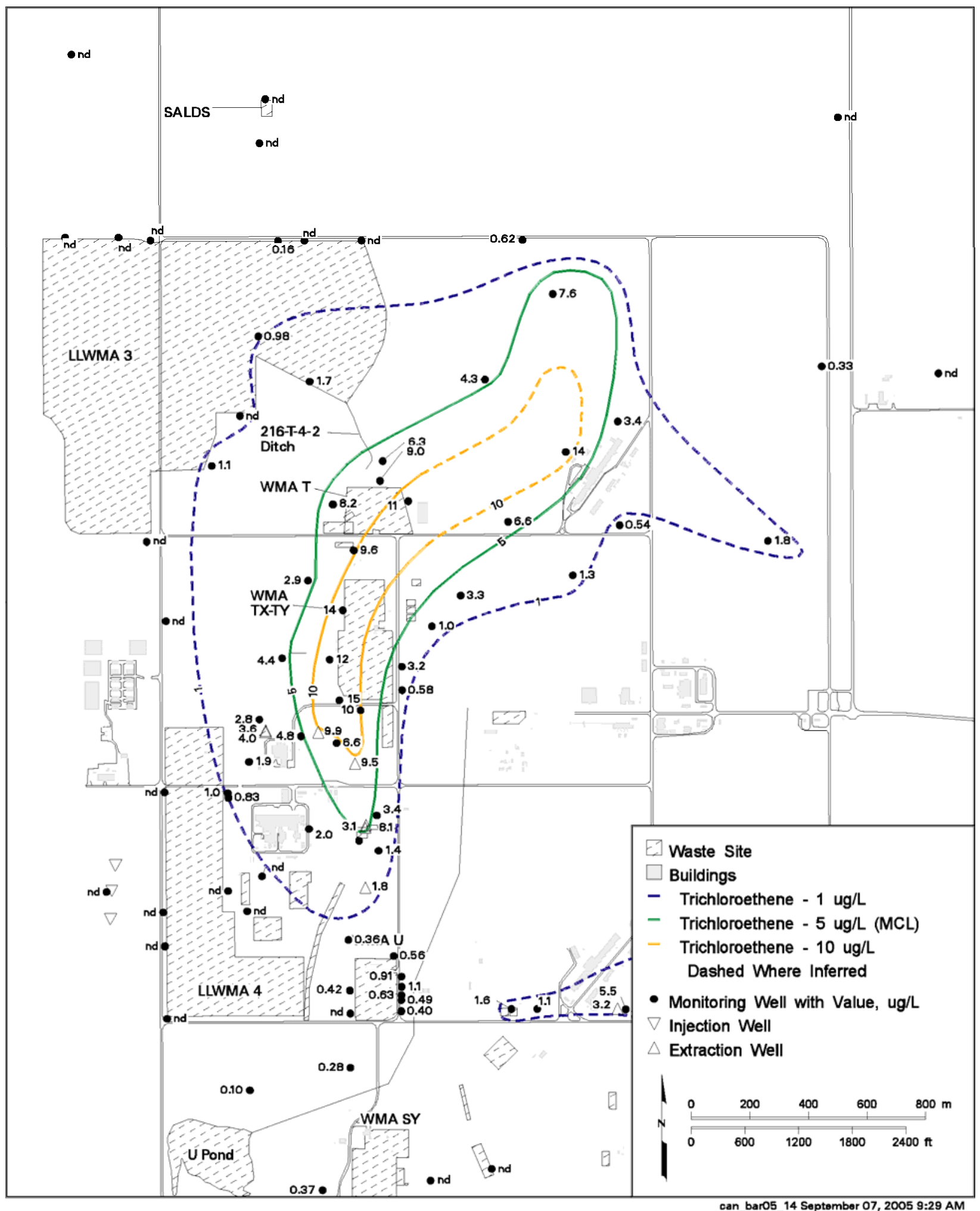

Figure A.5. Trichloroethene Concentrations in the 200 West Area, FY 2004 


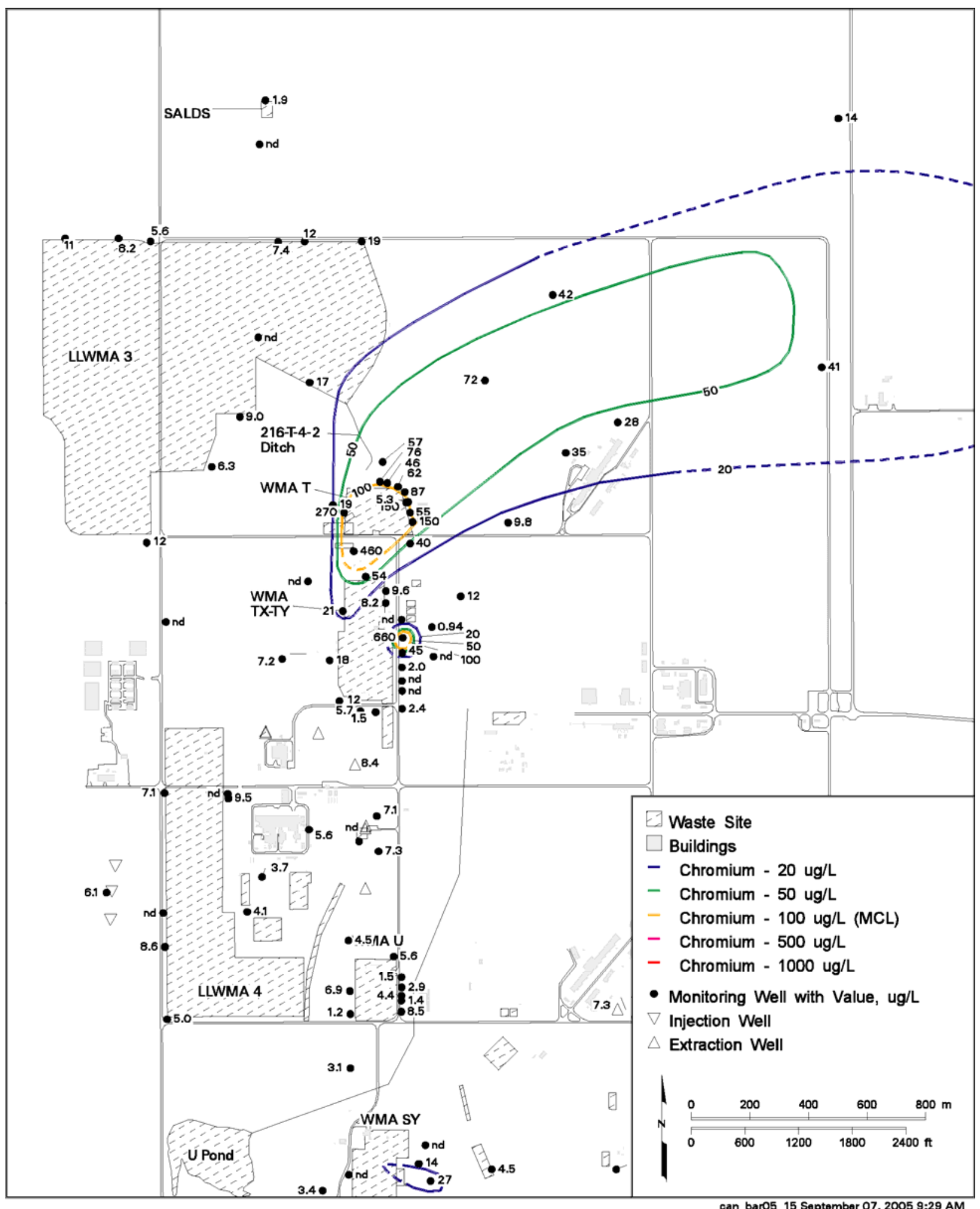

Figure A.6. Chromium Concentrations in the 200 West Area, FY 2004 


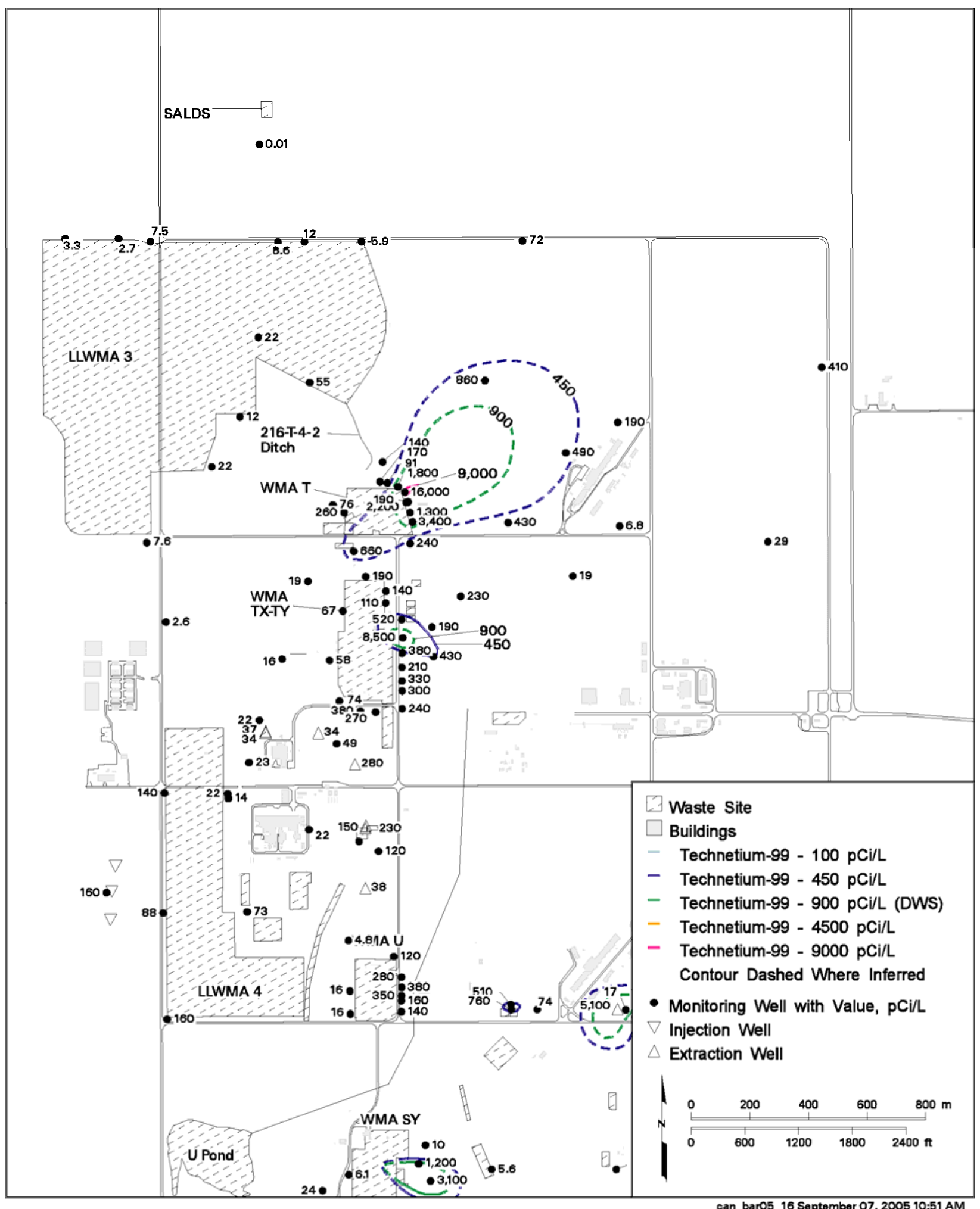

Figure A.7. Technetium-99 Concentrations in the 200 West Area, FY 2004 


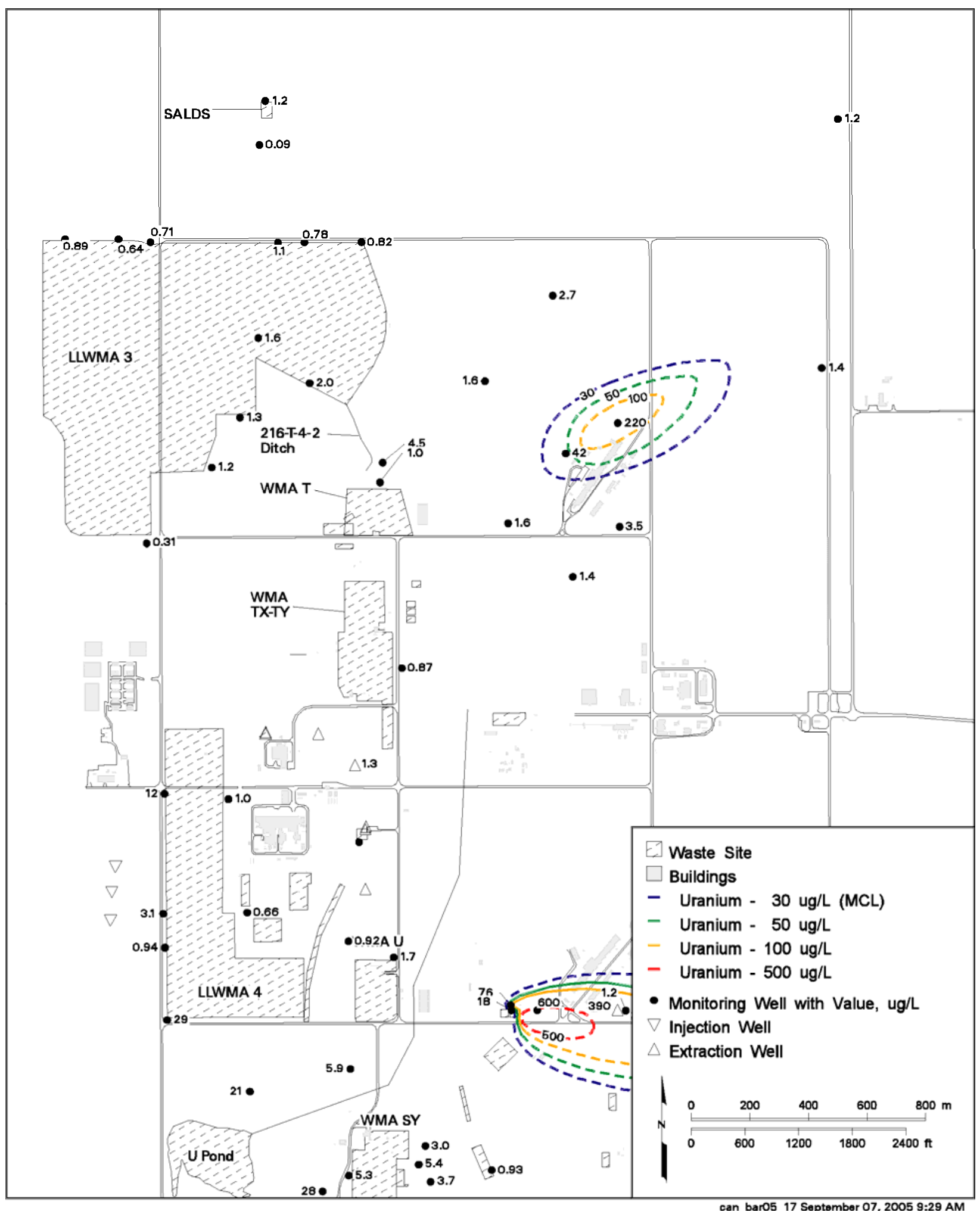

Figure A.8. Uranium Concentrations in the 200 West Area, FY 2004 


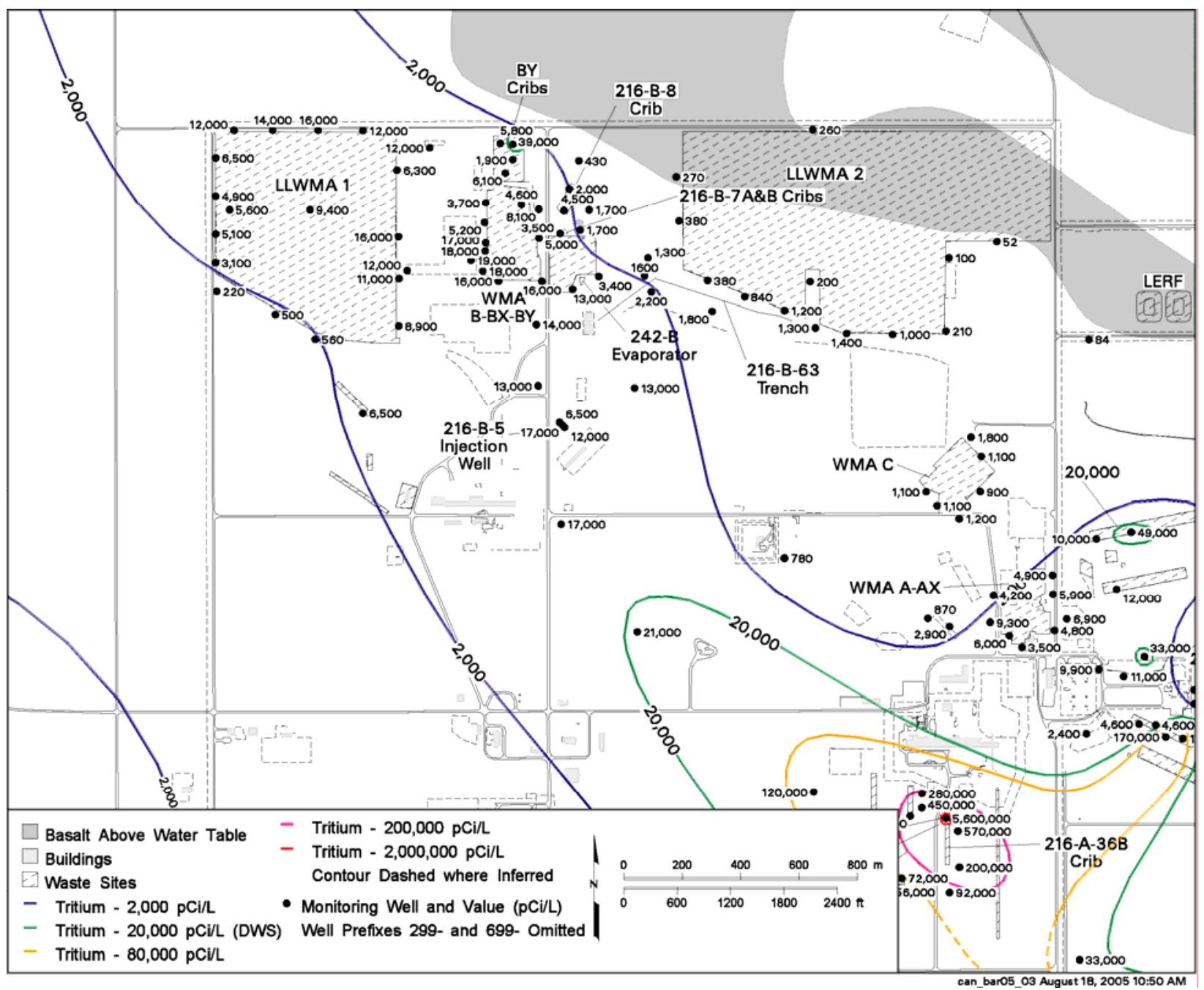

Figure A.9. Tritium Concentrations in the 200 East Area, FY 2004 


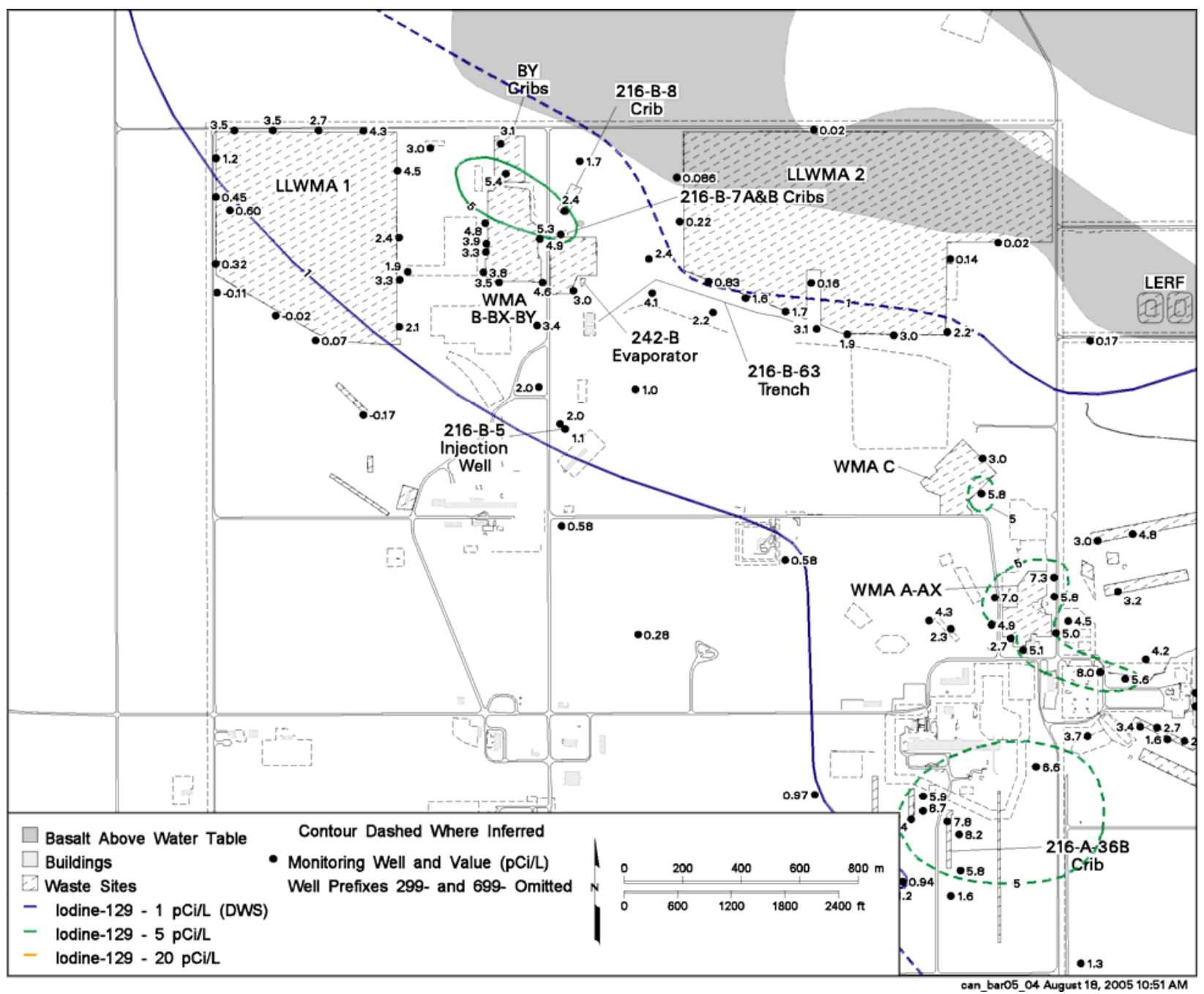

Figure A.10. Iodine-129 Concentrations in the 200 East Area, FY 2004 


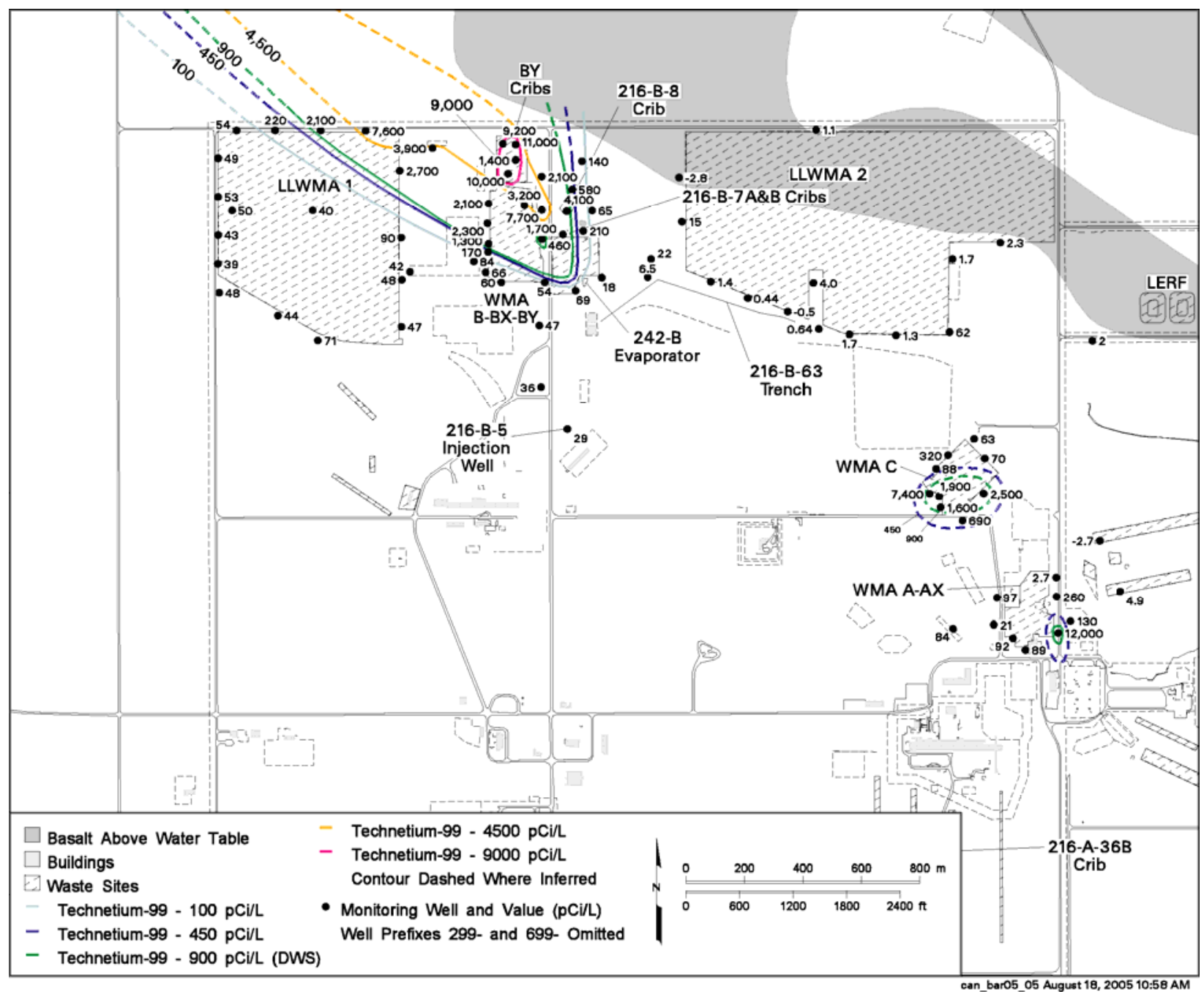

Figure A.11. Technetium-99 Concentrations in the 200 East Area, FY 2004 


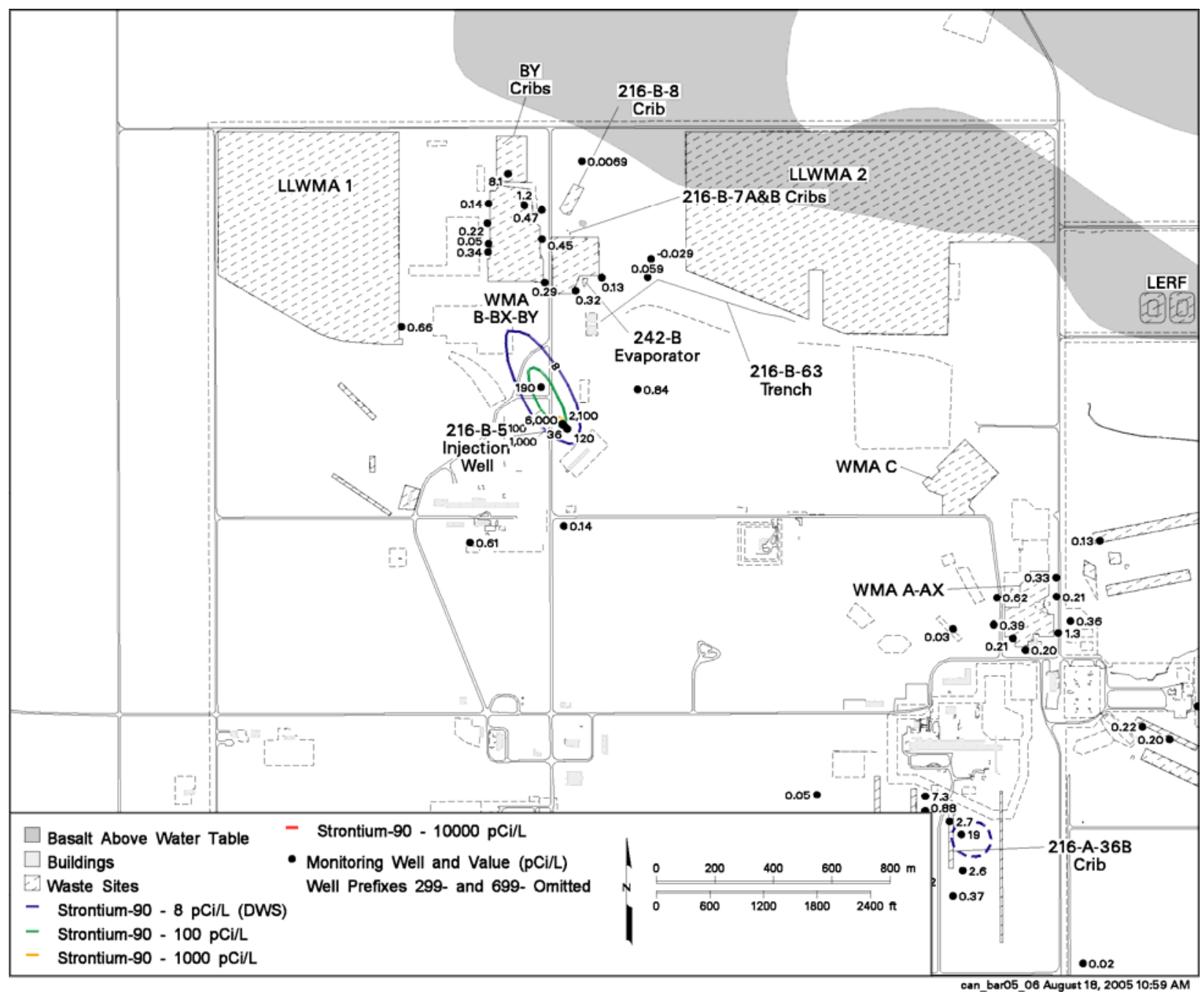

Figure A.12. Strontium-90 Concentrations in the 200 East Area, FY 2004 


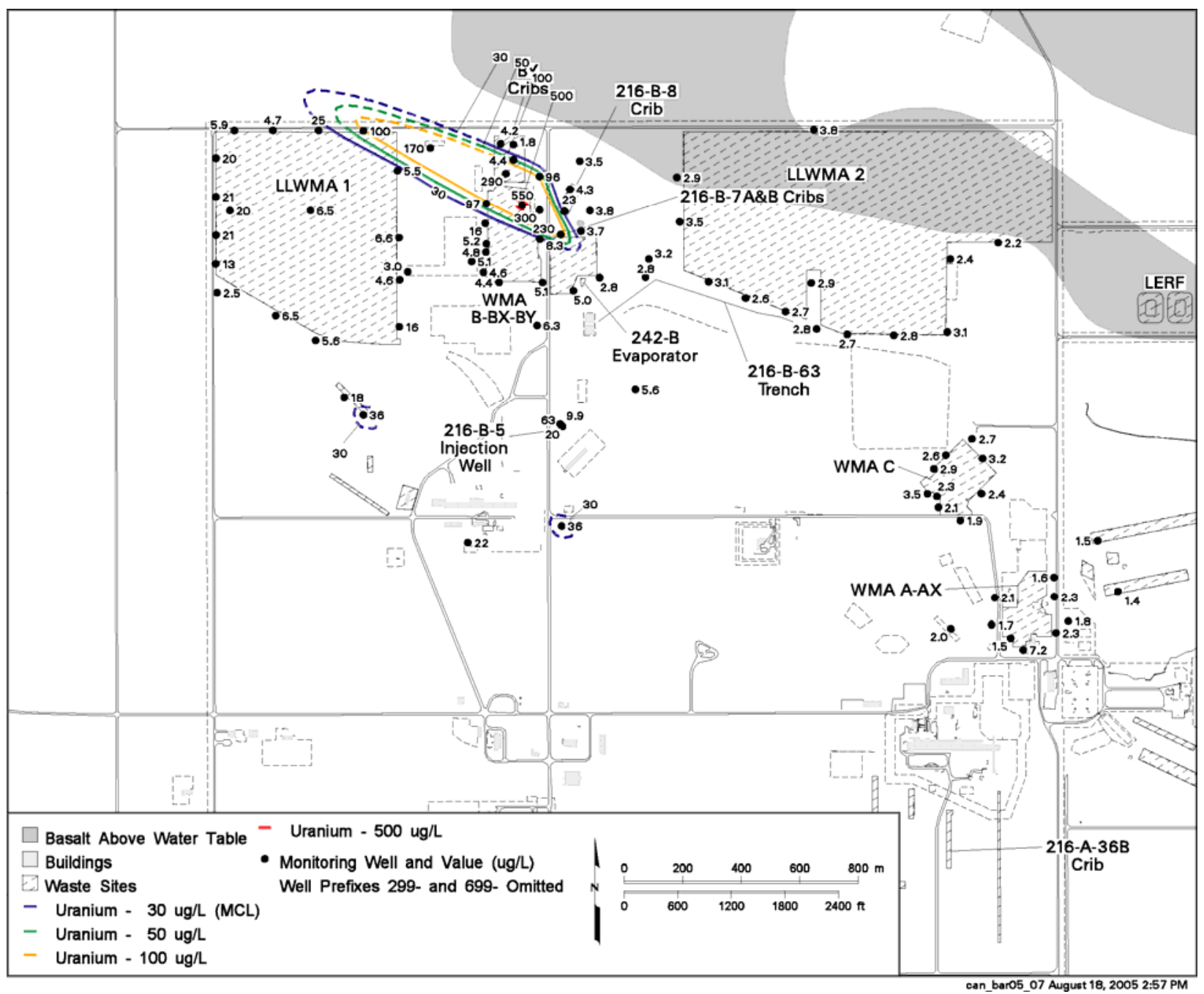

Figure A.13. Uranium Concentrations in the 200 East Area, FY 2004 


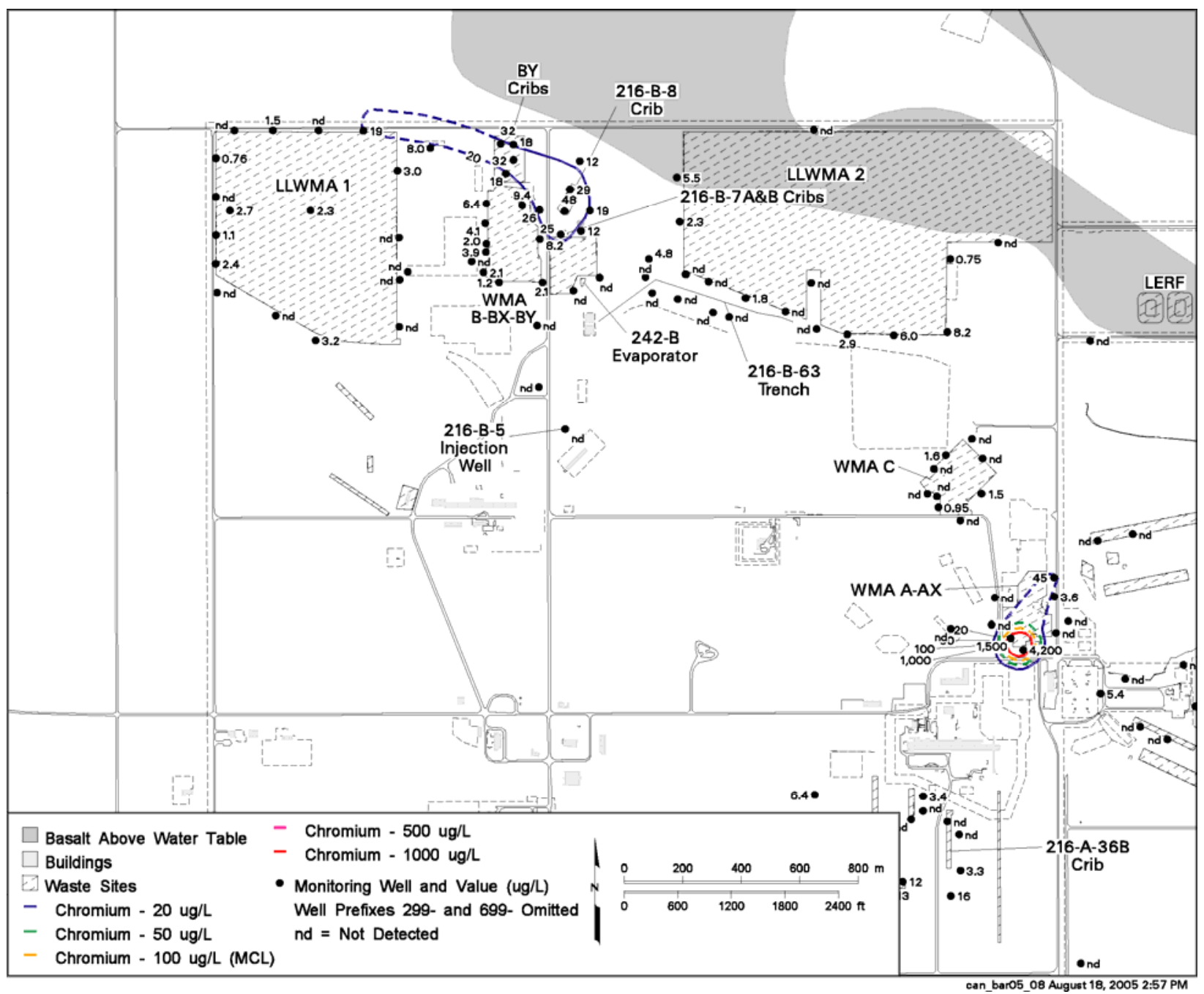

Figure A.14. Chromium Concentrations in the 200 East Area, FY 2004 


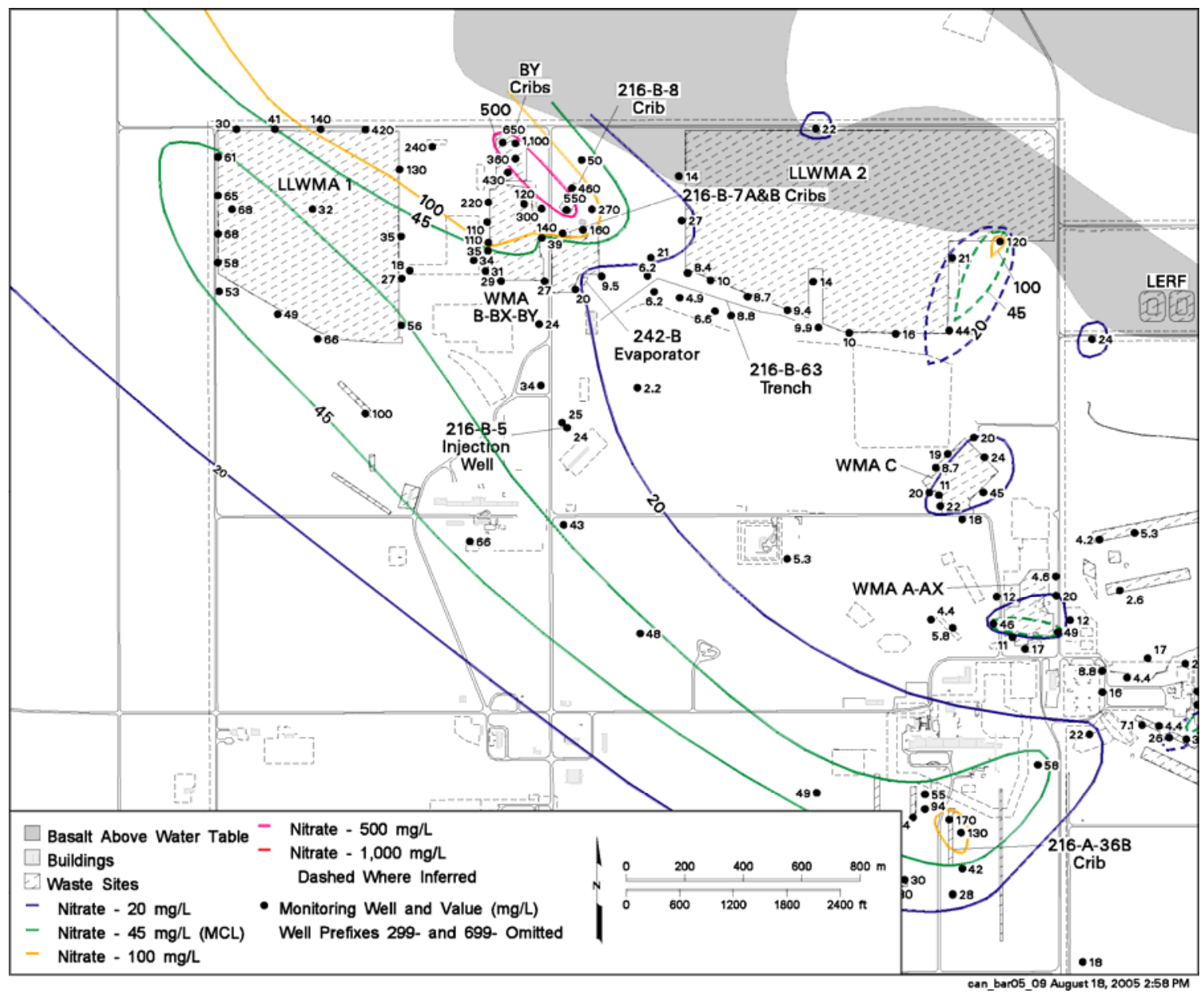

Figure A.15. Nitrate Concentrations in the 200 East Area, FY 2004 


\section{Appendix B}

Calculation of Relative Hazard Index for Constituents of Concern in the Groundwater Ingestion Pathway 


\section{Appendix B}

\section{Calculation of Relative Hazard Index for Constituents of Concern in the Groundwater Ingestion Pathway}

The "Relative Hazard Index" (RHI), as in DOE/RL-2000-72, Rev. 0, is computed by dividing the source quantity $(\mathrm{Ci})$ by the $\mathrm{DCG}(\mathrm{pCi} / \mathrm{L})$. Inventories listed in that document are shown in the tables below as "App A." Inventories for all subsequent dates through October 2004 are taken from the following references:

$$
\begin{array}{ll}
\text { 8/98-7/99: } & \text { Wood 2001a. } \\
\text { 8/99-7/00: } & \text { Wood 2001b } \\
\text { 8/00-7/01: } & \text { Wood 2001c } \\
\text { 8/01-7/02: } & \text { Wood 2002 } \\
\text { 8/02-7/03: } & \text { Wood 2003 } \\
\text { 8/03-10/04: } & \text { Wood 2005 }
\end{array}
$$

Discussion of the method used to derive the RHI is found in Chou et al. (1997) and Horton et al. (2000, Appendix B).

\section{References}

Chou, C. J., V. G. Johnson, S. P. Reidel, and J. W. Shade. 1997. TWRS Phase I Privatization Site Environmental Baseline and Characterization Plan. HNF-SD-TWR-EV-001, Rev. 0, Numatec Hanford Company, Richland, Washington.

DOE Order 5400.5. "Radiation Protection of the Public and the Environment." U.S. Department of Energy, Washington, D.C.

Horton, D. G., S. P. Reidel, Yi-ju Chien, and R. M. Mitchell. 2000. Remote-Handled Low-Activity Waste Disposal Facility Preoperational Monitoring Plan. RPP-6877, Rev 0, CH2M HILL Hanford Group, Inc., Richland, Washington.

Wood, M. I. 2001a. 1998-1999 Annual Review of the 200 West and 200 East Areas Performance Assessments. HNF-7561, Rev 0, Fluor Hanford Company, Inc., Richland, Washington.

Wood, M. I. 2001b. 1999-2000 Annual Review of the 200 West and 200 East Area Performance Assessments. HNF-7562, Rev. 0, Fluor Hanford Company, Inc., Richland, Washington.

Wood, M. I. 2001c. Performance Assessment Review Report, 2000-2001 Annual Review of the 200 West and 200 East Area Performance Assessments. Correspondence FH-0105097, Fluor Hanford Company, Inc., Richland, Washington. 
Wood, M. I. 2002. Performance Assessment Review Report, 2001-2002 Annual Review of the 200 West and 200 East Area Performance Assessments. Correspondence FH-0204558, Fluor Hanford Company, Inc., Richland, Washington.

Wood, M. I. 2003. Performance Assessment Review Report, 2002-2003 Annual Review of the 200 West and 200 East Area Performance Assessments. Correspondence FH-0304003, Fluor Hanford Company, Inc., Richland, Washington.

Wood, M. I. 2005. Performance Assessment Review Report, 2003-2004 Annual Review of the 200 West and 200 East Area Performance Assessments. Correspondence FH-0501152, Fluor Hanford Company, Inc., Richland, Washington. 
Table B.1. Relative Hazard Index for the 200 East Area, Burial Grounds 218-E-10 and 218-E-12B

\section{8-E-10}

radionuclide

inventories (Ci)

total

DCG $(p C i / L)$

$\mathrm{RHI}(\mathrm{L})$

$\%$ of $\mathrm{RHI}$

\begin{tabular}{lrrrrrrr} 
period & C-14 & & Cl-36 & \multicolumn{1}{l}{ I-129 } & Se-79 & Tc-99 & U-238 \\
App. A & 0 & 0 & 0 & 0 & $5.07 \mathrm{E}-03$ & $1.14 \mathrm{E}-02$ & \\
$8 / 98-7 / 99$ & 0 & 0 & 0 & 0 & $0.00 \mathrm{E}+00$ & $0.00 \mathrm{E}+00$ & \\
$8 / 99-7 / 00$ & 0 & 0 & 0 & 0 & $5.07 \mathrm{E}-03$ & $1.05 \mathrm{E}-02$ & \\
$8 / 00-7 / 01$ & 0 & 0 & 0 & 0 & 0 & 0 & \\
$8 / 01-7 / 02$ & 0 & 0 & 0 & 0 & 0 & 0 & \\
$8 / 02-7 / 03$ & 0 & 0 & 0 & 0 & 0 & 0 & \\
$8 / 03-10 / 04$ & 0 & 0 & 0 & 0 & 0 & 0 & \\
& 0 & $0.00 \mathrm{E}+00$ & $0.00 \mathrm{E}+00$ & $0.00 \mathrm{E}+00$ & $1.01 \mathrm{E}-02$ & $2.19 \mathrm{E}-02$ & \\
& 70000 & 50000 & 500 & 20000 & 100000 & 600 & total \\
& 0 & $0.00 \mathrm{E}+00$ & $0.00 \mathrm{E}+00$ & $0.00 \mathrm{E}+00$ & $1.01 \mathrm{E}-07$ & $3.65 \mathrm{E}-05$ & $3.66 \mathrm{E}-05$ \\
& $0.00 \%$ & $0.00 \%$ & $0.00 \%$ & $0.00 \%$ & $0.28 \%$ & $99.72 \%$ & $100.00 \%$
\end{tabular}

218-E-12B

radionuclide

period

C-14

$\mathrm{Cl}-36$

I-129

Se-79

Tc-99

U-238

inventories (Ci)

App. A

8/98-7/99

$8 / 99-7 / 00$

8/00-7/01

$8 / 01-7 / 02$

$8 / 02-7 / 03$

total

DCG(pCi/L)

8/03-10/04
$1.31 \mathrm{E}+02 \quad 5.56 \mathrm{E}-03 \quad 2.94 \mathrm{E}-03 \quad 2.31 \mathrm{E}-05 \quad 8.08 \mathrm{E}-01 \quad 4.68 \mathrm{E}-03$

$\begin{array}{llllll}0.00 \mathrm{E}+00 & 0.00 \mathrm{E}+00 \quad 0.00 \mathrm{E}+00 & 0.00 \mathrm{E}+00 & 0.00 \mathrm{E}+00 & 1.91 \mathrm{E}-06\end{array}$

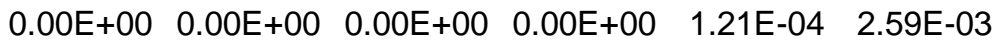

$\begin{array}{rrrrrr}0 & 0 & 0 & 0 & 0 & 7.59 \mathrm{E}-03\end{array}$

$\begin{array}{llllll}0 & 0 & 0 & 0 & 3.09 \mathrm{E}-04 & 6.44 \mathrm{E}-04\end{array}$

$\begin{array}{llllll}0 & 0 & 0 & 0 & 0 & 0\end{array}$

$\begin{array}{llllll}0 & 0 & 0 & 0 & 0 & 8.72 \mathrm{E}-03\end{array}$

1.31E+02 5.56E-03 2.94E-03 2.31E-05 8.08E-01 2.42E-02

$\begin{array}{llllll}70000 & 50000 & 500 & 20000 & 100000 & 600\end{array}$

$0.001871 \quad 1.11 \mathrm{E}-07 \quad 5.88 \mathrm{E}-06 \quad 1.16 \mathrm{E}-09 \quad 8.08 \mathrm{E}-06 \quad 4.04 \mathrm{E}-05 \quad 1.93 \mathrm{E}-03$

$\begin{array}{lllllll}97.17 \% & 0.01 \% & 0.31 \% & 0.00 \% & 0.42 \% & 2.10 \% & 100.00 \%\end{array}$

$\%$ of $\mathrm{RHI}$

Notes: Derived concentration guide (DCG) from DOE Order 5400.5

"App. A" are values taken from DOE/RL-2000-72 rev0 tables A1a and A1b 
Table B.2. Relative Hazard Index for the 200 West Area

\section{8-W-3A}

radionuclide inventories (Ci)

total

DCG $(\mathrm{pCi} / \mathrm{L})$

$\mathrm{RHI}(\mathrm{L})$

$\%$ of $\mathrm{RHI}$

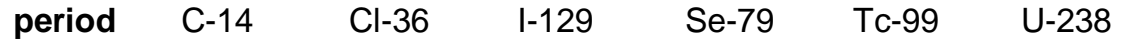

$\begin{array}{lllllll}\text { App. A } & 1.74 \mathrm{E}+00 & 2.00 \mathrm{E}-04 & 1.44 \mathrm{E}-02 & 1.12 \mathrm{E}-04 & 2.88 \mathrm{E}-01 & 1.11 \mathrm{E}-01\end{array}$

$\begin{array}{lllllllll}8 / 98-7 / 99 & 0.00 \mathrm{E}+00 & 0.00 \mathrm{E}+00 & 0.00 \mathrm{E}+00 & 0.00 \mathrm{E}+00 & 0.00 \mathrm{E}+00 & 0.00 \mathrm{E}+00\end{array}$

$\begin{array}{lllllllll}8 / 99-7 / 00 & 0.00 \mathrm{E}+00 & 0.00 \mathrm{E}+00 & 0.00 \mathrm{E}+00 & 0.00 \mathrm{E}+00 & 0.00 \mathrm{E}+00 & 0.00 \mathrm{E}+00\end{array}$

$\begin{array}{rrrrrrr}8 / 00-7 / 01 & 0 & 0 & 0 & 0 & 0 & 7.59 \mathrm{E}-03\end{array}$

$\begin{array}{lllllll}8 / 01-7 / 02 & 0 & 0 & 0 & 0 & 3.09 \mathrm{E}-04 & 6.44 \mathrm{E}-04\end{array}$

$8 / 02-7 / 03$

$8 / 03-10 / 04$

0

2.00E-04 1.44E-02

70000

50000

2.49E-05

$9.74 \%$

2.88E-05

0

$0 \quad 0 \quad 0.00 \mathrm{E}+00$

$1.12 \mathrm{E}-04 \quad 2.88 \mathrm{E}-01 \quad 1.19 \mathrm{E}-01$

$20000 \quad 100000 \quad 600$

5.60E-09 2.88E-06 1.99E-04

$0.00 \% \quad 1.13 \% \quad 77.85 \%$

total

2.55E-04

$100.00 \%$

\section{8-W-3AE}

radionuclide inventories (Ci)

total

DCG $(p C i / L)$

$\mathrm{RHI}(\mathrm{L})$

$\%$ of $\mathrm{RHI}$

218-W-5

radionuclide inventories (Ci)

total DCG $(\mathrm{pCi} / \mathrm{L})$

$\mathrm{RHI}(\mathrm{L})$

$\%$ of $\mathrm{RHI}$

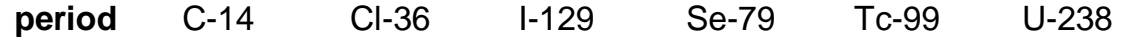

$\begin{array}{lllllll}\text { App. A } & 1.39 \mathrm{E}+01 & 1.35 \mathrm{E}-03 & 4.01 \mathrm{E}-04 & 9.77 \mathrm{E}-03 & 9.80 \mathrm{E}+00 & 6.22 \mathrm{E}+01\end{array}$

8/98-7/99 2.88E+00 $\quad 1.00 \mathrm{E}-03 \quad 2.76 \mathrm{E}-06 \quad 0.00 \mathrm{E}+00 \quad 5.83 \mathrm{E}-02 \quad 1.07 \mathrm{E}-01$

8/99-7/00 3.58E-01 $0.00 \mathrm{E}+00 \quad 0.00 \mathrm{E}+00 \quad 8.39 \mathrm{E}-06 \quad 5.85 \mathrm{E}-01 \quad 2.57 \mathrm{E}-02$

$\begin{array}{lllllll}8 / 00-7 / 01 & 4.84 \mathrm{E}-04 & 0 & 0 & 1.05 \mathrm{E}-02 & 2.34 \mathrm{E}+01 & 4.49 \mathrm{E}+01\end{array}$

8/01-7/02 1.11E-03 $\quad 0 \quad 003.95 \mathrm{E}-05 \quad 5.47 \mathrm{E}-02 \quad 9.88 \mathrm{E}-01$

$\begin{array}{lllllll}8 / 02-7 / 03 & 1.24 \mathrm{E}+01 & 0 & 0 & 0 & 1.50 \mathrm{E}-01 & 3.54 \mathrm{E}-01\end{array}$

8/03-10/04 1.87E-02 $4.52 \mathrm{E}-05 \quad 0 \quad 2.11 \mathrm{E}-06 \quad 001.63 \mathrm{E}-01$

$2.96 \mathrm{E}+01 \quad 2.40 \mathrm{E}-03 \quad 4.04 \mathrm{E}-04 \quad 2.03 \mathrm{E}-02 \quad 3.40 \mathrm{E}+01 \quad 1.09 \mathrm{E}+02$

$\begin{array}{llllll}70000 & 50000 & 500 & 20000 & 100000 & 600\end{array}$

$\begin{array}{lllllll}0.23 \% & 0.00 \% & 0.00 \% & 0.00 \% & 0.19 \% & 99.58 \% & 100.00 \%\end{array}$

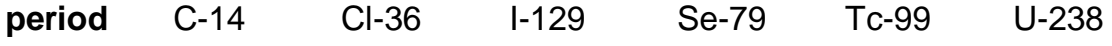

$\begin{array}{lllllll}\text { App. A } \quad 5.28 \mathrm{E}+00 & 2.04 \mathrm{E}-03 & 3.44 \mathrm{E}-02 & 5.00 \mathrm{E}-03 & 3.95 \mathrm{E}-01 & 6.66 \mathrm{E}-01\end{array}$

8/98-7/99 3.67E-03 $0.00 \mathrm{E}+00 \quad 0.00 \mathrm{E}+00 \quad 0.00 \mathrm{E}+00 \quad 1.82 \mathrm{E}-03 \quad 1.19 \mathrm{E}-02$

8/99-7/00 3.12E-02 2.40E-06 2.59E-05 $1.63 \mathrm{E}-09 \quad 4.07 \mathrm{E}-02 \quad 5.95 \mathrm{E}-03$

8/00-7/01 2.40E-02 $\quad 0 \quad 2.90 \mathrm{E}-05 \quad 0.00 \mathrm{E}+00 \quad 1.37 \mathrm{E}-02 \quad 6.21 \mathrm{E}-03$

8/01-7/02 5.40E-03 $\quad 0 \quad 2.94 \mathrm{E}-04 \quad 2.15 \mathrm{E}-04 \quad 4.69 \mathrm{E}-03 \quad 1.05 \mathrm{E}-02$

8/02-7/03 7.06E-03 $\quad 0 \quad 5.37 \mathrm{E}-04 \quad 2.06 \mathrm{E}-05 \quad 3.92 \mathrm{E}-02 \quad 1.76 \mathrm{E}-02$

8/03-10/04 4.32E-02 $0.00 \mathrm{E}+00 \quad 1.32 \mathrm{E}-03 \quad 3.57 \mathrm{E}-04 \quad 1.21 \mathrm{E}-02 \quad 8.36 \mathrm{E}-03$

$5.39 \mathrm{E}+00 \quad 2.04 \mathrm{E}-03 \quad 3.66 \mathrm{E}-02 \quad 5.59 \mathrm{E}-03 \quad 5.07 \mathrm{E}-01 \quad 7.27 \mathrm{E}-01$

$\begin{array}{lllllll}70000 & 50000 & 500 & 20000 & 100000 & 600 & \text { total }\end{array}$

7.71E-05 4.08E-08 7.32E-05 2.80E-07 5.07E-06 1.21E-03 $1.37 \mathrm{E}-03$

$\begin{array}{lllllll}5.64 \% & 0.00 \% & 5.36 \% & 0.02 \% & 0.37 \% & 88.61 \% & 100.00 \%\end{array}$ 
Table B.2. (contd)

\section{8-W-4C}

radionuclide inventories (Ci)

total

$\mathrm{DCG}(\mathrm{pCi} / \mathrm{L})$

$\mathrm{RHI}(\mathrm{L})$

$\%$ of $\mathrm{RHI}$

$\begin{array}{llrrrrrr}\text { period } & \text { C-14 } & \text { Cl-36 } & \text { I-129 } & \text { Se-79 } & \text { Tc-99 } & \text { U-238 } & \\ \text { App. A } & 2.63 \mathrm{E}+00 & 1.61 \mathrm{E}-05 & 1.46 \mathrm{E}-03 & 2.71 \mathrm{E}-05 & 1.64 \mathrm{E}+01 & 4.01 \mathrm{E}+01 & \\ 8 / 98-7 / 99 & 0.00 \mathrm{E}+00 & 0.00 \mathrm{E}+00 & 0.00 \mathrm{E}+00 & 0.00 \mathrm{E}+00 & 0.00 \mathrm{E}+00 & 0.00 \mathrm{E}+00 & \\ 8 / 99-7 / 00 & 0.00 \mathrm{E}+00 & 0.00 \mathrm{E}+00 & 0.00 \mathrm{E}+00 & 0.00 \mathrm{E}+00 & 0.00 \mathrm{E}+00 & 5.56 \mathrm{E}-05 & \\ 8 / 00-7 / 01 & 0.00 \mathrm{E}+00 & 0.00 \mathrm{E}+00 & 0.00 \mathrm{E}+00 & 0.00 \mathrm{E}+00 & 1.71 \mathrm{E}-03 & 7.11 \mathrm{E}-03 & \\ 8 / 01-7 / 02 & 0.00 \mathrm{E}+00 & 0.00 \mathrm{E}+00 & 0.00 \mathrm{E}+00 & 0.00 \mathrm{E}+00 & 0.00 \mathrm{E}+00 & 2.87 \mathrm{E}-04 & \\ 8 / 02-7 / 03 & 0.00 \mathrm{E}+00 & 0.00 \mathrm{E}+00 & 0.00 \mathrm{E}+00 & 2.06 \mathrm{E}-05 & 3.92 \mathrm{E}-02 & 1.76 \mathrm{E}-02 & \\ 8 / 03-10 / 04 & 0.00 \mathrm{E}+00 & 0.00 \mathrm{E}+00 & 0.00 \mathrm{E}+00 & 0.00 \mathrm{E}+00 & 1.01 \mathrm{E}-05 & 3.21 \mathrm{E}-06 & \\ & 2.63 \mathrm{E}+00 & 1.61 \mathrm{E}-05 & 1.46 \mathrm{E}-03 & 4.77 \mathrm{E}-05 & 1.64 \mathrm{E}+01 & 4.01 \mathrm{E}+01 & \\ & 70000 & 50000 & 500 & 20000 & 100000 & 600 & \text { total } \\ & 3.76 \mathrm{E}-05 & 3.22 \mathrm{E}-10 & 2.92 \mathrm{E}-06 & 2.39 \mathrm{E}-09 & 1.64 \mathrm{E}-04 & 6.69 \mathrm{E}-02 & 6.71 \mathrm{E}-02 \\ & 0.06 \% & 0.00 \% & 0.00 \% & 0.00 \% & 0.25 \% & 99.69 \% & 100.00 \%\end{array}$

218-W-4B

radionuclide

inventories (Ci)

total

period

C-1

Cl-36

I-129

Se-79

Tc-99

U-238

App. A

$\begin{array}{lllllll}0.00 \mathrm{E}+00 & 0.00 \mathrm{E}+00 & 5.00 \mathrm{E}-01 & 0.00 \mathrm{E}+00 & 0.00 \mathrm{E}+00 & 0.00 \mathrm{E}+00\end{array}$

8/98-7/99

$\begin{array}{lllllllll}0.00 \mathrm{E}+00 & 0.00 \mathrm{E}+00 & 0.00 \mathrm{E}+00 & 0.00 \mathrm{E}+00 & 0.00 \mathrm{E}+00 & 0.00 \mathrm{E}+00\end{array}$

$8 / 99-7 / 00$

$\begin{array}{lllllll}0.00 \mathrm{E}+00 & 0.00 \mathrm{E}+00 & 0.00 \mathrm{E}+00 & 0.00 \mathrm{E}+00 & 0.00 \mathrm{E}+00 & 0.00 \mathrm{E}+00\end{array}$

$8 / 00-7 / 01$

$\begin{array}{lllllllll}0.00 \mathrm{E}+00 & 0.00 \mathrm{E}+00 & 0.00 \mathrm{E}+00 & 0.00 \mathrm{E}+00 & 0.00 \mathrm{E}+00 & 0.00 \mathrm{E}+00\end{array}$

$8 / 01-7 / 02$

$\begin{array}{llllllll}0.00 \mathrm{E}+00 & 0.00 \mathrm{E}+00 & 0.00 \mathrm{E}+00 & 0.00 \mathrm{E}+00 & 0.00 \mathrm{E}+00 & 0.00 \mathrm{E}+00\end{array}$

$8 / 02-7 / 03$

$\begin{array}{llllll}0.00 E+00 & 0.00 E+00 & 0.00 E+00 & 0.00 E+00 & 0.00 E+00 & 0.00 E+00\end{array}$

8/03-10/04

$\operatorname{DCG}(\mathrm{pCi} / \mathrm{L})$

$\begin{array}{ll}0.00 \mathrm{E}+00 & 0.00 \mathrm{E}+00 \\ 0.00 \mathrm{E}+00 & 0.00 \mathrm{E}+00\end{array}$

$0.00 \mathrm{E}+00 \quad 0.00 \mathrm{E}+00 \quad 0.00 \mathrm{E}+00 \quad 0.00 \mathrm{E}+00$

$\mathrm{RHI}(\mathrm{L})$

70000

50000

$5.00 \mathrm{E}-01$

$0.00 \mathrm{E}+00 \quad 0.00 \mathrm{E}+00$

500

$0.00 \mathrm{E}+000.00$

$0.00 \mathrm{E}+00 \quad 0.00 \mathrm{E}+00$

$\%$ of $\mathrm{RHI}$

$0.00 \%$

$1.00 \mathrm{E}-03$
$100.00 \%$ 20000

100000

600 total

Notes: Derived concentration guide (DCG) from DOE Order 5400.5

"App. A" are values taken from DOE/RL-2000-72 rev0 tables A1a and A1b 


\section{Appendix C}

Sampling and Analysis Plan for Performance Assessment Monitoring of the Low-Level Burial Grounds 


\section{Appendix C}

\section{Sampling and Analysis Plan for Performance Assessment Monitoring of the Low-Level Burial Grounds}

This appendix provides current groundwater sampling information for the low-level burial grounds. Derivation of the constituents of concern is discussed in Section 4 of this report. Groundwater monitoring wells currently in the network are shown in Tables C.1 through C.4, by low-level waste management area, along with well screen information, water levels, and the height of the water column remaining in the wells. Additional (replacement) wells are shown that are scheduled for drilling during the remainder of fiscal year 2006 and beyond. Tables C.5 through C.9 list, by well, the constituents of concern, the sampling frequencies, and whether the well monitors upgradient or downgradient of the facility. Figures C.1 through C. 4 show the current well network configurations at each of the four low-level waste management areas.

\section{References}

Hartman, M. J., L. F. Morasch, and W. D. Webber (eds.). 2005. Hanford Site Groundwater Monitoring for Fiscal Year 2004. PNNL-15070, Pacific Northwest National Laboratory, Richland, Washington.

Rieger, J. T. and M. J. Hartman. 2005. Fiscal Year 2005 Integrated Monitoring Plan for the Hanford Groundwater Performance Assessment Project. PNNL-15176, Pacific Northwest National Laboratory, Richland, Washington.

Poston, T. M., R. W. Hanf, R. L. Dirkes, and L. F. Morasch (eds.). 2004. Hanford Site Environmental Report for Calendar Year 2003. PNNL-14687, Pacific Northwest National Laboratory, Richland, Washington. 
Table C.1. Well Information for Low-Level Waste Management Area 1

\begin{tabular}{|c|c|c|c|c|c|c|}
\hline Well Name & $\begin{array}{l}\text { Well } \\
\text { ID }\end{array}$ & $\begin{array}{l}\text { Elev Top } \\
\text { Screen } \\
(\mathrm{m} \mathrm{msl})\end{array}$ & $\begin{array}{c}\text { Elev Bottom } \\
\text { Screen } \\
(\mathrm{m} \mathrm{msl})\end{array}$ & $\begin{array}{c}\text { Water-Level } \\
\text { Elevation } \\
(\mathrm{m} \mathrm{msl})\end{array}$ & $\begin{array}{c}\text { Water-Level } \\
\text { Date }\end{array}$ & $\begin{array}{c}\text { Thickness Water } \\
\text { Column }(\mathrm{m})\end{array}$ \\
\hline 299-E28-26 & A4822 & 124.79 & 118.70 & 122.14 & $8 / 6 / 2005$ & 3.44 \\
\hline 299-E28-27 & A4823 & 125.53 & 116.08 & 122.09 & $8 / 30 / 2005$ & 6.01 \\
\hline 299-E28-28 & A4824 & 125.65 & 119.56 & 122.10 & $8 / 6 / 2005$ & 2.54 \\
\hline 299-E32-2 & A 4830 & 126.03 & 116.59 & 122.09 & $7 / 14 / 2005$ & 5.50 \\
\hline 299-E32-3 & A4831 & 125.85 & 119.76 & 122.12 & $7 / 14 / 2005$ & 2.36 \\
\hline 299-E32-4 & A4832 & 125.05 & 115.90 & 122.08 & $7 / 14 / 2005$ & 6.18 \\
\hline 299-E32-5 & A4833 & 125.49 & 119.09 & 122.13 & $7 / 14 / 2005$ & 3.04 \\
\hline 299-E32-6 & A4834 & 125.65 & 119.25 & 122.10 & $7 / 14 / 2005$ & 2.85 \\
\hline 299-E32-7 & A4835 & 125.65 & 119.25 & 122.12 & $7 / 14 / 2005$ & 2.87 \\
\hline 299-E32-8 & A4836 & 125.11 & 119.01 & 122.09 & $7 / 14 / 2005$ & 3.08 \\
\hline 299-E32-9 & A4837 & 125.62 & 119.52 & 122.10 & $7 / 14 / 2005$ & 2.58 \\
\hline 299-E32-10 & A5432 & 125.95 & 119.85 & 122.11 & $8 / 6 / 2005$ & 2.26 \\
\hline 299-E33-28 & A4852 & 125.03 & 118.32 & 122.12 & $8 / 6 / 2005$ & 3.80 \\
\hline 299-E33-29 & A4853 & 125.59 & 117.36 & 122.09 & $8 / 6 / 2005$ & 4.73 \\
\hline 299-E33-30 & A4855 & 125.13 & 118.42 & 121.88 & $8 / 6 / 2005$ & 3.46 \\
\hline 299-E33-34 & A4859 & 126.49 & 120.39 & 122.12 & $3 / 22 / 2005$ & 1.84 \\
\hline 299-E33-35 & A4860 & 126.68 & 120.28 & 122.07 & $8 / 6 / 2005$ & 1.79 \\
\hline
\end{tabular}

Table C.2. Well Information for Low-Level Waste Management Area 2

\begin{tabular}{||l|c|c|c|c|c|c||}
\hline \hline Well Name & Well ID & $\begin{array}{c}\text { Elev Top } \\
\text { Screen } \\
(\mathrm{m} \mathrm{msl})\end{array}$ & $\begin{array}{c}\text { Elev Bottom } \\
\text { Screen } \\
(\mathrm{m} \mathrm{msl})\end{array}$ & $\begin{array}{c}\text { Water-Level } \\
\text { Elevation } \\
(\mathrm{m} \mathrm{msl})\end{array}$ & $\begin{array}{c}\text { Water-Level } \\
\text { Date } \\
(\mathrm{m})\end{array}$ & $\begin{array}{c}\text { Thickness Water } \\
\text { Column }(\mathrm{m})\end{array}$ \\
\hline \hline 299-E27-8 & A4817 & 125.62 & 116.17 & 122.12 & $9 / 24 / 2005$ & 5.95 \\
\hline 299-E27-9 & A4818 & 125.24 & 117.93 & 122.24 & $9 / 24 / 2005$ & 4.19 \\
\hline 299-E27-10 & A4808 & 126.19 & 117.66 & 122.14 & $7 / 27 / 2005$ & 4.48 \\
\hline 299-E27-11 & A4809 & 126.16 & 119.76 & 122.08 & $9 / 24 / 2005$ & 2.32 \\
\hline 299-E27-17 & A4815 & 125.60 & 119.20 & 122.11 & $9 / 24 / 2005$ & 2.91 \\
\hline 299-E34-2 & A4877 & 125.75 & 119.66 & 122.13 & $7 / 19 / 2005$ & 2.47 \\
\hline 299-E34-9 & A4884 & 126.89 & 120.49 & 122.10 & $8 / 6 / 2005$ & 1.61 \\
\hline 299-E34-10 & A4875 & 126.59 & 120.19 & 122.12 & $9 / 24 / 2005$ & 1.93 \\
\hline 299-E34-12 & A5433 & 126.55 & 120.15 & 122.04 & $7 / 19 / 2005$ & 1.89 \\
\hline \hline
\end{tabular}


Table C.3. Well Information for Low-Level Waste Management Area 3

\begin{tabular}{|c|c|c|c|c|c|c|}
\hline Well Name & Well ID & $\begin{array}{l}\text { Elev Top } \\
\text { Screen } \\
(\mathrm{m} \mathrm{msl})\end{array}$ & $\begin{array}{c}\text { Elev Bottom } \\
\text { Screen } \\
(\mathrm{m} \mathrm{msl})\end{array}$ & $\begin{array}{c}\text { Water-Level } \\
\text { Elevation } \\
(\mathrm{m} \mathrm{msl})\end{array}$ & $\begin{array}{c}\text { Water-Level } \\
\text { Date }\end{array}$ & $\begin{array}{c}\text { Thickness Water } \\
\text { Column (m) }\end{array}$ \\
\hline 299-W7-3 & A5009 & 69.60 & 61.06 & 136.09 & $9 / 23 / 2005$ & 75.03 \\
\hline 299-W7-4 & A5010 & 143.14 & 134.00 & 136.49 & $3 / 25 / 2005$ & 2.49 \\
\hline 299-W7-12 & A5007 & 142.99 & 136.59 & 136.71 & $9 / 1 / 2005$ & 0.12 \\
\hline 299-W8-1 & A5016 & 142.36 & 132.60 & 137.08 & $9 / 23 / 2005$ & 4.48 \\
\hline 299-W10-14 & A4891 & 83.42 & 77.33 & 136.96 & $9 / 23 / 2005$ & 59.63 \\
\hline 299-W10-20 & A5439 & 142.33 & 136.26 & 137.75 & $9 / 27 / 2005$ & 0.49 \\
\hline $299-W 10-25^{(a)}$ & C4987 & & & & & \\
\hline $299-W 10-29^{(a)}$ & C4988 & & & & & \\
\hline $299-W 10-30^{(\mathrm{a})}$ & C4989 & & & & & \\
\hline
\end{tabular}

Table C.4. Well Information for Low-Level Waste Management Area 4

\begin{tabular}{|c|c|c|c|c|c|c|}
\hline Well Name & Well ID & $\begin{array}{l}\text { Elev Top } \\
\text { Screen } \\
(\mathrm{m} \mathrm{msl})\end{array}$ & $\begin{array}{c}\text { Elev Bottom } \\
\text { Screen } \\
(\mathrm{m} \mathrm{msl})\end{array}$ & $\begin{array}{c}\text { Water-Level } \\
\text { Elevation } \\
(\mathrm{m} \mathrm{msl})\end{array}$ & $\begin{array}{c}\text { Water-Level } \\
\text { Date }\end{array}$ & $\begin{array}{c}\text { Thickness Water } \\
\text { Column (m) }\end{array}$ \\
\hline 299-W15-15 & A4919 & 145.19 & 135.44 & 137.80 & $3 / 23 / 2004$ & 2.36 \\
\hline 299-W15-17 & A4921 & 80.31 & 77.26 & 137.31 & $3 / 23 / 2004$ & 60.05 \\
\hline 299-W15-30 & B2410 & 142.83 & 130.64 & 137.292 & $3 / 23 / 2004$ & 6.65 \\
\hline $299-W 15-83^{(a)}$ & C4683 & 137.83 & 126.17 & 138.01 & $8 / 18 / 2005$ & 11.84 \\
\hline $299-W 15-94^{(\mathrm{a})}$ & C4684 & 137.45 & 126.78 & 136.94 & $9 / 27 / 2005$ & 10.16 \\
\hline $299-W 15-152^{(a)}$ & C4685 & 137.47 & 126.76 & 137.08 & $9 / 28 / 2005$ & 10.32 \\
\hline $299-\mathrm{W} 15-224^{(\mathrm{b})}$ & C4986 & & & & & \\
\hline 299-W18-21 & A4933 & 144.51 & 135.37 & 137.91 & $3 / 23 / 2004$ & 2.54 \\
\hline 299-W18-22 & A4934 & 77.15 & 67.70 & 137.80 & $3 / 23 / 2004$ & 70.10 \\
\hline $299-W 18-23$ & A4935 & 145.80 & 136.35 & 137.89 & $3 / 23 / 2004$ & 1.54 \\
\hline
\end{tabular}




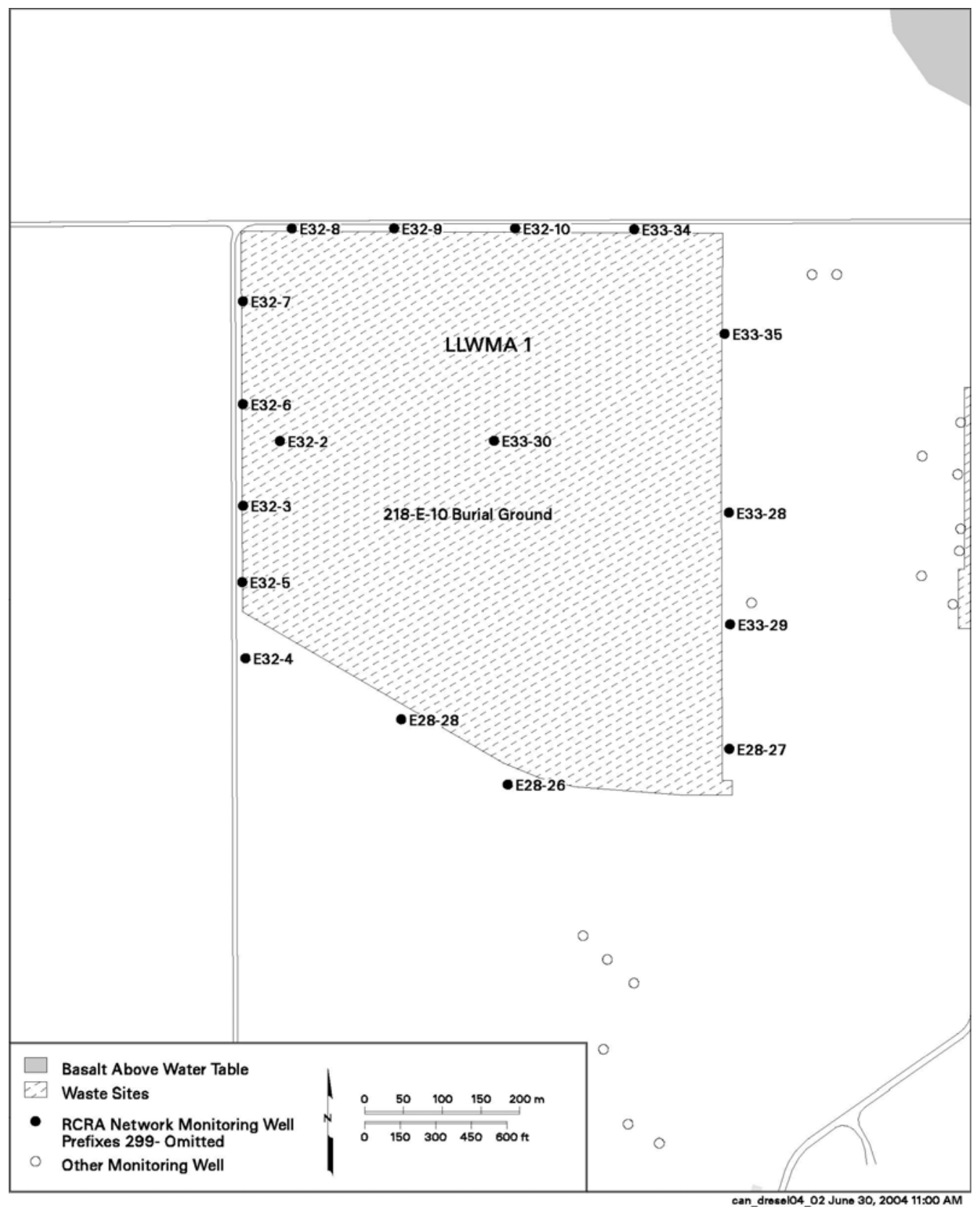

Figure C.1. LLWMA 1 (after Dresel 2004) 


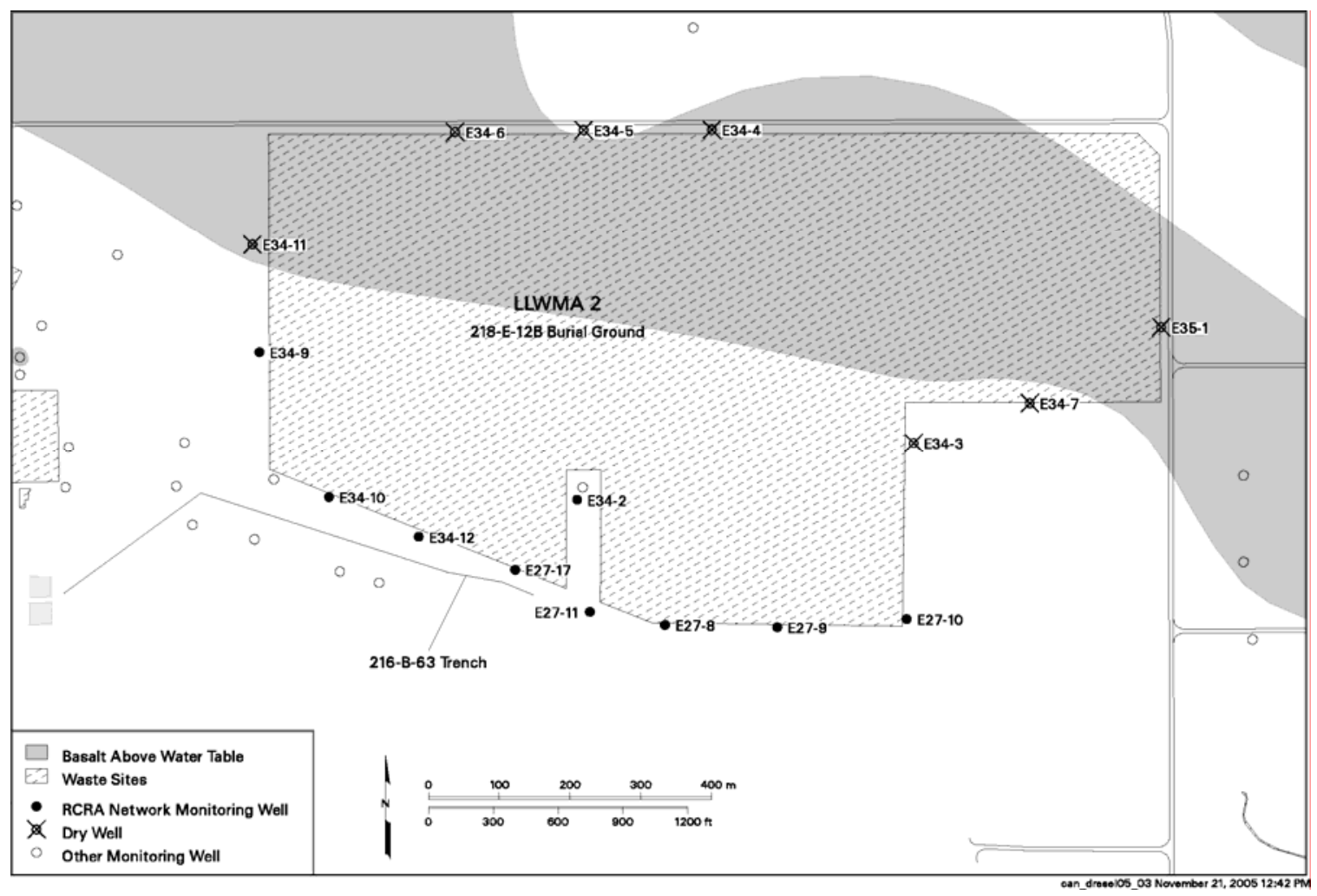

Figure C.2. LLWMA 2 (after Dresel 2004) 


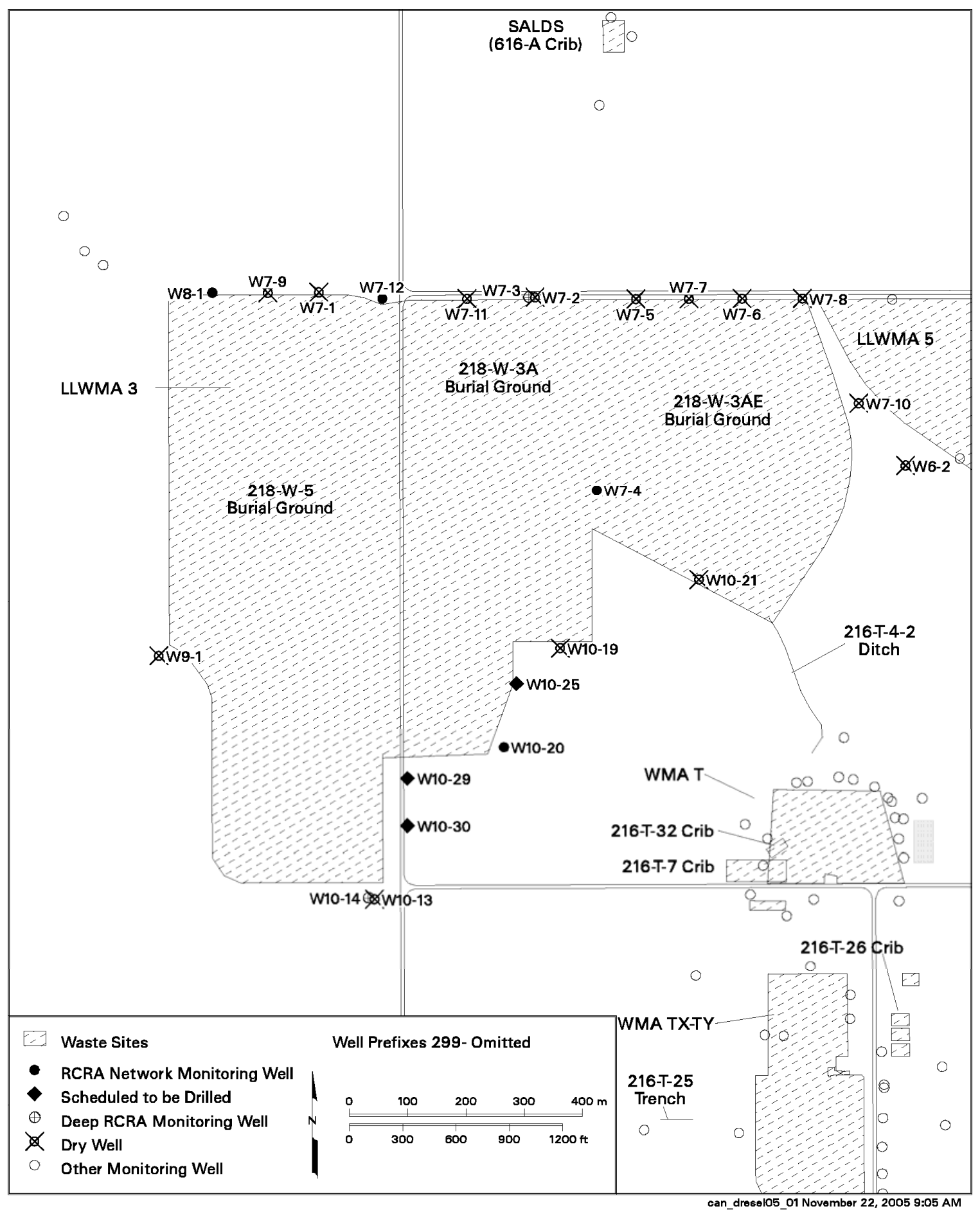

Figure C.3. LLWMA 3 (after Dresel 2004) 


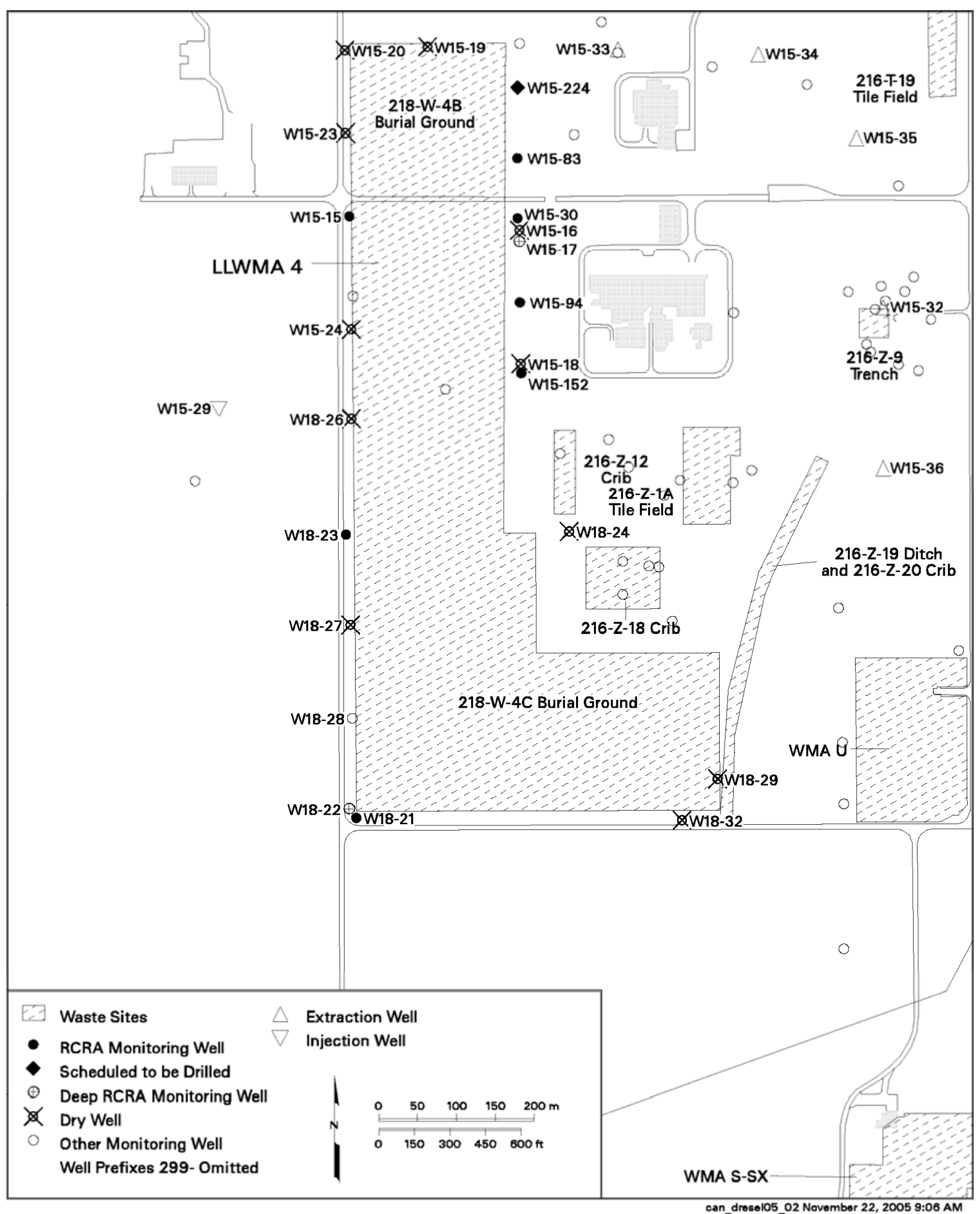

Figure C.4. LLWMA 4 (after Dresel 2004) 
Table C.5. Groundwater Monitoring Wells for Low-Level Waste Management Area 1 (adapted from Hartman et al. 2005 and Rieger and Hartman 2005)

\begin{tabular}{|c|c|c|c|c|c|c|c|}
\hline \multirow[b]{2}{*}{ Well Name } & \multirow[b]{2}{*}{ Purpose } & \multirow{2}{*}{ 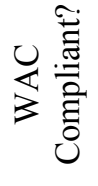 } & \multirow{2}{*}{ 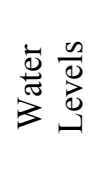 } & \multicolumn{4}{|c|}{ Constituents to Support Performance Assessment } \\
\hline & & & & Iodine-129 & Technetium-99 & Tritium & Uranium \\
\hline $299-E 28-26^{87}$ & Upgradient & $\mathrm{C}$ & $\mathrm{S}$ & $\mathrm{S}$ & S & $\mathrm{S}$ & $\mathrm{S}$ \\
\hline 299-E28-2787 & Upgradient & $\mathrm{C}$ & $\mathrm{S}$ & $\mathrm{S}$ & $\mathrm{S}$ & $\mathrm{S}$ & $\mathrm{S}$ \\
\hline $299-\mathrm{E} 28-28^{90}$ & Upgradient & $\mathrm{C}$ & $\mathrm{S}$ & $\mathrm{S}$ & $\mathrm{S}$ & $\mathrm{S}$ & $\mathrm{S}$ \\
\hline $299-\mathrm{E} 32-2^{87}$ & Downgradient & $\mathrm{C}$ & $\mathrm{S}$ & $\mathrm{S}$ & $\mathrm{S}$ & $\mathrm{S}$ & $\mathrm{S}$ \\
\hline $299-\mathrm{E} 32-3^{87}$ & Downgradient & $\mathrm{C}$ & $\mathrm{S}$ & $\mathrm{S}$ & $\mathrm{S}$ & $\mathrm{S}$ & $\mathrm{S}$ \\
\hline $299-\mathrm{E} 32-4^{87}$ & Upgradient & $\mathrm{C}$ & $\mathrm{S}$ & $\mathrm{S}$ & $\mathrm{S}$ & $\mathrm{S}$ & $\mathrm{S}$ \\
\hline $299-E 32-5^{89}$ & Downgradient & $\mathrm{C}$ & $\mathrm{S}$ & $\mathrm{S}$ & $\mathrm{S}$ & S & S \\
\hline $299-\mathrm{E} 32-6^{91}$ & Downgradient & $\mathrm{C}$ & $\mathrm{S}$ & $\mathrm{S}$ & $\mathrm{S}$ & $\mathrm{S}$ & $\mathrm{S}$ \\
\hline $299-E 32-7^{91}$ & Downgradient & $\mathrm{C}$ & $\mathrm{S}$ & $\mathrm{S}$ & $\mathrm{S}$ & $\mathrm{S}$ & $\mathrm{S}$ \\
\hline $299-\mathrm{E} 32-8^{91}$ & Downgradient & $\mathrm{C}$ & $\mathrm{S}$ & $\mathrm{S}$ & $\mathrm{S}$ & $\mathrm{S}$ & $\mathrm{S}$ \\
\hline $299-\mathrm{E} 32-9^{91}$ & Downgradient & $\mathrm{C}$ & $S$ & $\mathrm{~S}$ & $\mathrm{~S}$ & S & S \\
\hline 299-E32-10 & Downgradient & $\mathrm{C}$ & $\mathrm{S}$ & $\mathrm{S}$ & $\mathrm{S}$ & S & $\mathrm{S}$ \\
\hline $299-E 33-28^{87}$ & Upgradient & $\mathrm{C}$ & $\mathrm{S}$ & $\mathrm{S}$ & $\mathrm{S}$ & S & $\mathrm{S}$ \\
\hline 299-E33-29 ${ }^{87}$ & Upgradient & $\mathrm{C}$ & $\mathrm{S}$ & $\mathrm{S}$ & $\mathrm{S}$ & $S$ & $\mathrm{~S}$ \\
\hline $299-E 33-30^{87}$ & Downgradient & $\mathrm{C}$ & $\mathrm{S}$ & $\mathrm{S}$ & $\mathrm{S}$ & $S$ & $\mathrm{~S}$ \\
\hline $299-E 33-34^{90}$ & Downgradient & $\mathrm{C}$ & $\mathrm{S}$ & $\mathrm{S}$ & $\mathrm{S}$ & $S$ & $\mathrm{~S}$ \\
\hline $299-E 33-35^{90}$ & Upgradient & $\mathrm{C}$ & $\mathrm{S}$ & $\mathrm{S}$ & $\mathrm{S}$ & $S$ & $\mathrm{~S}$ \\
\hline \multicolumn{8}{|c|}{$\begin{array}{l}\text { Superscript }=\text { Year of installation. } \\
\text { All wells monitor the top of the unconfined aquifer. } \\
\mathrm{C}=\text { Well is constructed as a WAC 173-160, Part Two, resource protection well. } \\
\mathrm{S}=\text { To be sampled semiannually. }\end{array}$} \\
\hline
\end{tabular}


Table C.6. Groundwater Monitoring Wells for Low-Level Waste Management Area 2 (adapted from Hartman et al. 2005 and Rieger and Hartman 2005).

\begin{tabular}{|c|c|c|c|c|c|c|c|}
\hline \multirow[b]{2}{*}{ Well Name } & \multirow[b]{2}{*}{ Purpose } & \multirow{2}{*}{ 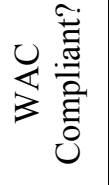 } & \multirow{2}{*}{$\begin{array}{ll}\overrightarrow{0} & 0 \\
\frac{0}{0} & 0 \\
3 & 0 \\
\end{array}$} & \multicolumn{4}{|c|}{ Constituents to Support Performance Assessment } \\
\hline & & & & Iodine-129 & Technetium-99 & Tritium & Uranium \\
\hline $299-\mathrm{E} 27-8^{87}$ & downgradient & $\mathrm{C}$ & $\mathrm{S}$ & S & S & $\mathrm{S}$ & $\mathrm{S}$ \\
\hline $299-E 27-9^{87}$ & downgradient & $\mathrm{C}$ & $\mathrm{S}$ & $\mathrm{S}$ & $\mathrm{S}$ & $\mathrm{S}$ & $\mathrm{S}$ \\
\hline $299-\mathrm{E} 27-10^{90}$ & upgradient & $\mathrm{C}$ & $\mathrm{S}$ & $\mathrm{S}$ & $\mathrm{S}$ & $\mathrm{S}$ & $\mathrm{S}$ \\
\hline $299-E 27-11^{89}$ & downgradient & $\mathrm{C}$ & S & $\mathrm{S}$ & S & $\mathrm{S}$ & $\mathrm{S}$ \\
\hline 299-E27-17 ${ }^{91}$ & downgradient & $\mathrm{C}$ & $\mathrm{S}$ & $\mathrm{S}$ & $\mathrm{S}$ & $\mathrm{S}$ & $\mathrm{S}$ \\
\hline $299-E 34-2^{87}$ & downgradient & $\mathrm{C}$ & $\mathrm{S}$ & $S$ & $S$ & $\mathrm{~S}$ & $\mathrm{~S}$ \\
\hline $299-\mathrm{E} 34-9^{91}$ & downgradient & $\mathrm{C}$ & $\mathrm{S}$ & $\mathrm{S}$ & $\mathrm{S}$ & $\mathrm{S}$ & $\mathrm{S}$ \\
\hline $299-E 34-10^{91}$ & downgradient & $\mathrm{C}$ & $\mathrm{S}$ & $\mathrm{S}$ & $\mathrm{S}$ & $\mathrm{S}$ & $\mathrm{S}$ \\
\hline $299-\mathrm{E} 34-12^{92}$ & downgradient & $\mathrm{C}$ & $\mathrm{S}$ & $\mathrm{S}$ & $\mathrm{S}$ & $\mathrm{S}$ & $\mathrm{S}$ \\
\hline \multicolumn{8}{|c|}{$\begin{array}{l}\text { Superscript =Year of installation. } \\
\text { All wells monitor the top of the unconfined aquifer. } \\
\mathrm{C}=\text { Well is constructed as a WAC 173-160, Part Two, resource protection well. } \\
\mathrm{S}=\text { To be sampled semiannually. }\end{array}$} \\
\hline
\end{tabular}


Table C.7. Groundwater Monitoring Wells for Low-Level Waste Management Area 3 (adapted from Hartman et al. 2005 and Rieger and Hartman 2005)

\begin{tabular}{|c|c|c|c|c|c|c|c|}
\hline \multirow[b]{2}{*}{ Well Name } & \multirow[b]{2}{*}{ Purpose } & \multirow{2}{*}{ 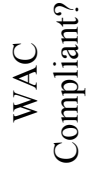 } & \multirow[t]{2}{*}{ 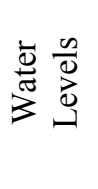 } & \multicolumn{4}{|c|}{ Contaminants of Concern } \\
\hline & & & & Iodine-129 & Technetium-99 & Tritium & Uranium \\
\hline $299-W 7-3^{87}$ & downgradient & $\mathrm{C}$ & $\mathrm{S}$ & $\mathrm{S}$ & $S$ & $\mathrm{~S}$ & $\mathrm{~S}$ \\
\hline $299-W 7-4^{87}$ & downgradient & $\mathrm{C}$ & $S$ & $S$ & $S$ & $\mathrm{~S}$ & $S$ \\
\hline $299-W 7-5^{87}$ & downgradient & $\mathrm{C}$ & $S$ & $S$ & $\mathrm{~S}$ & $\mathrm{~S}$ & $S$ \\
\hline $299-W 7-12^{91}$ & downgradient & $\mathrm{C}$ & $\mathrm{S}$ & $\mathrm{S}$ & $\mathrm{S}$ & $\mathrm{S}$ & $\mathrm{S}$ \\
\hline $299-W 8-1^{87}$ & downgradient & $\mathrm{C}$ & $\mathrm{S}$ & $\mathrm{S}$ & $\mathrm{S}$ & $\mathrm{S}$ & $\mathrm{S}$ \\
\hline $299-W 10-14^{87}$ & downgradient & $\mathrm{C}$ & $\mathrm{S}$ & $\mathrm{S}$ & $\mathrm{S}$ & $\mathrm{S}$ & $\mathrm{S}$ \\
\hline $299-W 10-20^{93}$ & downgradient & $\mathrm{C}$ & $\mathrm{S}$ & $\mathrm{S}$ & $\mathrm{S}$ & $\mathrm{S}$ & $\mathrm{S}$ \\
\hline $299-W 10-21^{93}$ & upgradient & $\mathrm{C}$ & $\mathrm{S}$ & $\mathrm{S}$ & S & $\mathrm{S}$ & $\mathrm{S}$ \\
\hline $299-\mathrm{W} 10-25^{(\mathrm{a})}$ & downgradient & $\mathrm{C}$ & $\mathrm{S}$ & $\mathrm{S}$ & $\mathrm{S}$ & $\mathrm{S}$ & $\mathrm{S}$ \\
\hline $299-W 10-29^{(a)}$ & downgradient & $\mathrm{C}$ & $\mathrm{S}$ & $\mathrm{S}$ & $\mathrm{S}$ & $\mathrm{S}$ & $\mathrm{S}$ \\
\hline $299-W 10-30^{(a)}$ & downgradient & $\mathrm{C}$ & $\mathrm{S}$ & $\mathrm{S}$ & $\mathrm{S}$ & $\mathrm{S}$ & $\mathrm{S}$ \\
\hline \multicolumn{8}{|c|}{$\begin{array}{l}\text { (a) Planned for installation in } 2006 \text {. } \\
\mathrm{N}=\text { Well construction is not compliant with WAC } 173-160 \text {, Part Two, resource protection well. } \\
\mathrm{C}=\text { Well is constructed as a WAC 173-160, Part Two, resource protection well. } \\
\mathrm{S}=\text { To be sampled semiannually. }\end{array}$} \\
\hline
\end{tabular}


Table C.8. Groundwater Monitoring Wells for Low-Level Waste Management Area 4 (adapted from Hartman et al. 2005 and Rieger and Hartman 2005)

\begin{tabular}{|c|c|c|c|c|c|c|c|}
\hline \multirow[b]{2}{*}{ Well Name } & \multirow[b]{2}{*}{ Purpose } & \multirow{2}{*}{ 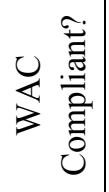 } & \multirow{2}{*}{ 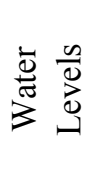 } & \multicolumn{4}{|c|}{ Constituents to Support Performance Assessment } \\
\hline & & & & Iodine-129 & Technetium-99 & Tritium & Uranium \\
\hline $299-W 15-15^{87}$ & upgradient & $\mathrm{C}$ & S & S & S & S & S \\
\hline $299-W 15-17^{87}$ & downgradient & $\mathrm{C}$ & S & $\mathrm{S}$ & $\mathrm{S}$ & S & S \\
\hline $299-W 15-30^{87}$ & downgradient & $\mathrm{C}$ & S & $\mathrm{S}$ & $\mathrm{S}$ & S & S \\
\hline $299-W 15-83^{05}$ & downgradient & $\mathrm{C}$ & $\mathrm{S}$ & $\mathrm{S}$ & $\mathrm{S}$ & $\mathrm{S}$ & $\mathrm{S}$ \\
\hline $299-W 15-94^{05}$ & downgradient & $\mathrm{C}$ & S & S & $S$ & $S$ & $S$ \\
\hline $299-W 15-152^{05}$ & downgradient & $\mathrm{C}$ & $S$ & S & $\mathrm{S}$ & S & S \\
\hline $299-W 15-224^{(a)}$ & downgradient & $\mathrm{C}$ & $S$ & $\mathrm{~S}$ & $\mathrm{~S}$ & $S$ & $S$ \\
\hline $299-W 18-21^{87}$ & upgradient & $\mathrm{C}$ & $S$ & $\mathrm{~S}$ & $\mathrm{~S}$ & $\mathrm{~S}$ & $\mathrm{~S}$ \\
\hline $299-W 18-22^{87}$ & upgradient & $\mathrm{C}$ & $\mathrm{S}$ & $\mathrm{S}$ & $\mathrm{S}$ & $S$ & $\mathrm{~S}$ \\
\hline $299-W 18-23^{87}$ & upgradient & $\mathrm{C}$ & $\mathrm{S}$ & $\mathrm{S}$ & $\mathrm{S}$ & $S$ & $\mathrm{~S}$ \\
\hline \multicolumn{8}{|c|}{$\begin{array}{l}\text { Superscript = Year of installation. } \\
\mathrm{N}=\text { Well construction is not compliant with WAC 173-160, Part Two, resource protection well. } \\
\mathrm{C}=\text { Well is constructed as a WAC 173-160, Part Two, resource protection well. } \\
\mathrm{S}=\text { To be sampled semiannually. }\end{array}$} \\
\hline
\end{tabular}

